\title{
Excess Sodium Tetraphenylborate and Intermediates Decomposition Studies
}

by

M. J. Barnes

Westinghouse Savannah River Company

Savannah River Site

Aiken, South Carolina 29808

R. A. Peterson

This paper was prepared in connection with work done under the above contract number with the U.S. Department of Energy. By acceptance of this paper, the publisher and/or recipient acknowledges the U.S. Government's right to retain a nonexclusive, royalty-free license in and to any copyright covering this paper, along with the right to reproduce and to authorize others to reproduce all or part of the copyrighted paper. 


\section{DISCLAIMER}

This report was prepared as an account of work sponsored by an agency of the United States Government. Neither the United States Government nor any agency thereof, nor any of their employees, makes any warranty, express or implied, or assumes any legal liability or responsibility for the accuracy, completeness, or usefulness of any information, apparatus, product, or process disclosed, or represents that its use would not infringe privately owned rights. Reference herein to any specific commercial product, process, or service by trade name, trademark, manufacturer, or otherwise does not necessarily constitute or imply its endorsement, recommendation, or favoring by the United States Government or any agency thereof. The views and opinions of authors expressed herein do not necessarily state or reflect those of the United States Government or any agency thereof.

This report has been reproduced directly from the best available copy.

Available to DOE and DOE contractors from the Office of Scientific and Technical Information, P. O. Box 62, Oak Ridge, TN 37831; prices available from (423) 576-8401.

Available to the public from the National Technical Information Service, U. S. Department of Commerce, 5285 Port Royal Road, Springfield, VA 22161. 


\section{DISCLAIMER}

Portions of this document may be illegible in electronic image products. Images are produced from the best available original document. 


\section{J. Barnes}

R. A. Peterson

Publication Date: October 2, 1998

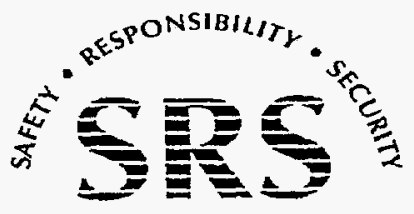




\section{EXCESS SODIUM TETRAPHENYLBORATE AND INTERMEDIATES DECOMPOSITION STUDIES}

\section{Authors}
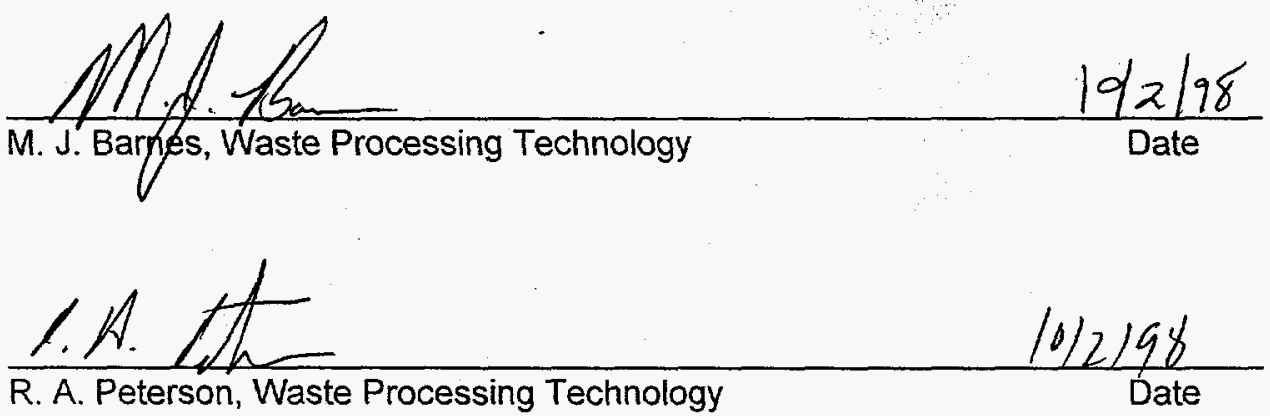

\section{Design Check}

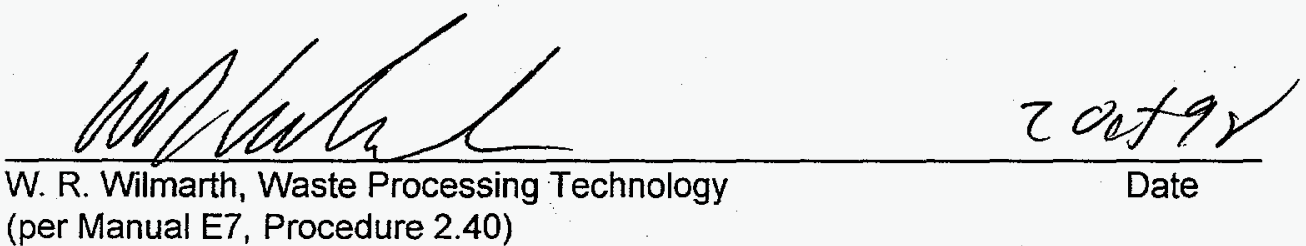
(per Manual E7, Procedure 2.40)

\section{Approvals/Review}
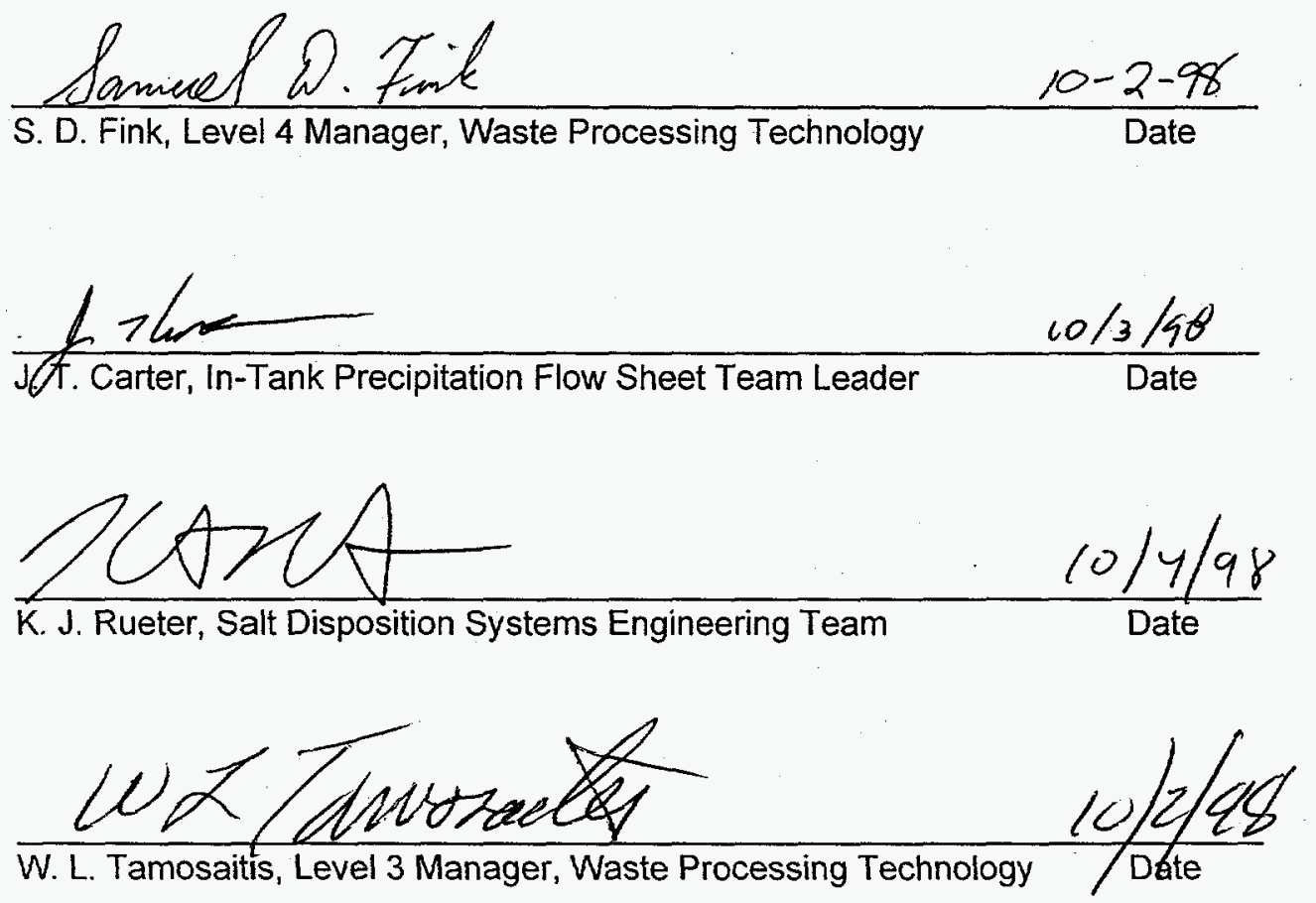


\subsection{Summary}

The stability of excess amounts of sodium tetraphenylborate (NaTPB) in the In-Tank Precipitation (ITP) facility depends on a number of variables. Concentration of palladium, initial benzene, and sodium ion as well as temperature provide the best opportunities for controlling the decomposition rate. This study examined the influence of these four variables on the reactivity of palladium-catalyzed sodium tetraphenylborate decomposition. Also, single effects tests investigated the reactivity of simulants with continuous stirring and nitrogen ventilation, with very high benzene concentrations, under washed sodium concentrations, with very high palladium concentrations, and with minimal quantities of excess NaTPB. These tests showed the following.

The testing demonstrates that current facility configuration does not provide assured safety of operations relative to the hazards of benzene (in particular to maintain the tank headspace below $60 \%$ of the lower flammability limit (Ifl) for benzene generation rates of greater than $7 \mathrm{mg} /(\mathrm{L} \cdot \mathrm{h})$ ) from possible accelerated reaction of excess NaTPB. Current maximal operating temperatures of $40^{\circ} \mathrm{C}$ and the lack of protection against palladium entering Tank $48 \mathrm{H}$ provide insufficient protection against the onset of the reaction. Similarly, control of the amount of excess NaTPB, purification of the organic, or limiting the benzene content of the slurry (via stirring) and ionic strength of the waste mixture prove inadequate to assure safe operation.

- Tests at $45^{\circ} \mathrm{C}$ exhibited decomposition rates that might be too large to provide significant margin to maintain the tank headspace below $60 \%$ of the LFL of the tank.

- All $25^{\circ} \mathrm{C}$ tests exhibited an average calculated benzene generation rate below the target of $7 \mathrm{mg} /(\mathrm{L} \cdot \mathrm{h})$. Analysis of the temperature data indicates that the catalyst apparently did not activate at $25^{\circ} \mathrm{C}$ during the test period.

- Only tests containing greater than $0.5 \mathrm{mg} / \mathrm{L}$ palladium and at temperatures equal to or greater than $35^{\circ} \mathrm{C}$ produced calculated benzene generation rates exceeding the target of $7 \mathrm{mg} /(\mathrm{L} \cdot \mathrm{h})$.

- Diluting the sodium concentration in the starting waste mixture to $3.5 \mathrm{M}$ does not significantly effect the generation rate of benzene.

- Initial benzene concentration does not statistically correlate with either the.decomposition rate of NaTPB or the observed induction period.

- Rapid decomposition of NaTPB, in the presence of palladium, occurs even without added initial concentrations of three phenylborate byproducts (i.e., in the absence of intermediates at the start of testing, NaTPB decomposition by a mechanism other than palladium catalysis produces a small, yet sufficient, concentration of intermediates). This result indicates purification of existing supplies of NaTPB to remove intermediates would not prevent NaTPB decomposition in ITP.

The experimental design also attempted to provide insight into the reaction mechanism by examining the dependence of the reaction on the presence of phenylborate byproducts, temperature, palladium concentration, and benzene content.

- Elevated concentrations of phenylborate intermediates do not accelerate the decomposition rate of NaTPB for either the palladium-catalyzed reaction or the reaction absent palladium.

- The presence of any one of the three intermediates - phenylboronic acid (1PB), diphenylborinic acid $(2 \mathrm{~PB})$, or triphenylborane (3PB) -- will activate palladium-catalyzed NaTPB decomposition.

- For tests that showed measurable reaction, the induction period varied from 0 to 487 hours. Only one reactive system - at $45^{\circ} \mathrm{C}$ with high palladium -- showed no induction period. 
- Sodium tetraphenylborate decomposition rates and length of induction periods correlate with temperature (i.e., a trend was observed that relatively fast reactions and short induction periods were observed at $45^{\circ} \mathrm{C}$, lower rates and longer induction periods were observed at $35^{\circ} \mathrm{C}$, and very low rates due to the lack of catalyst activation (extremely long or infinite induction periods) was observed at $25^{\circ} \mathrm{C}$.

- Sodium tetraphenylborate decomposition rates correlate with total palladium concentration.

This report was revised to incorporate extended reaction time data from all tests that contained NaTPB at the time that the original document was prepared. The data contained in this report six months of reaction time. Data collected after the initial document preparation did not lead to further conclusions or significant variation from the data reported in the original document.

\subsection{Introduction}

The In-Tank Precipitation (ITP) process uses NaTPB to precipitate cesium and potassium. During initial radioactive operation in the fall of 1995, excess NaTPB unexpectedly decomposed. [Ref. 1] Testing at the Savannah River Technology Center indicated that palladium, mercury, phenylborate intermediates, benzene, and tetraphenylborate solids form the most active simulant catalyst system observed. [Ref. 2 - 4] Copper demonstrates less catalytic activity than the palladium system for NaTPB decomposition.

[Ref. 5 - 7] Copper also catalyzes the decomposition of the resulting phenylborates: triphenylborane (3PB), diphenylborinic acid (2PB), and phenylboronic acid (1PB). [Ref. 8 - 9] Previous NaTPB decomposition testing probed the influence of a number of variables such as the presence of oxygen, agitation, and weight percent solids.

Concentration Storage and Transfer Engineering (CSTE) and the ITP Flowsheet Team requested the Waste Processing Technology Section conduct tests to examine whether a restricted range of conditions would provide for safe operation of the facility absent any physical modifications. This task also sought to (1) identify the intermediate(s) responsible for activating the palladium catalyst systems and (2) thoroughly examine and, if possible, quantify the influence of temperature, palladium concentration, benzene concentration, sodium ion concentration, and excess sodium tetraphenylborate concentration on the decomposition of excess NaTPB. This task serves as part of the DNFSB Recommendation 96-1 Implementation Plan [Ref. 10] as requested by CSTE and the ITP Flowsheet Team in Task Technical Request HLW-TTR-98038. [Ref. 11]

\subsection{Experimental}

This task consisted of two sets of tests. Set I sought to identify the intermediate(s) responsible for activating the palladium catalyst reaction. Set II sought to examine and potentially quantify the influence of temperature, palladium concentration, benzene concentration, sodium ion concentration, and excess NaTPB concentration. A discussion of the test conditions for each of the test sets follows.

\subsection{Set 1: Intermediates Testing}

The Intermediates Testing included two objectives:

- Determine which of the three phenylborate intermediates facilitates the start of the palladium catalyzed reaction (eight tests), and

- Determine if high concentrations of phenylborate intermediates catalyze the decomposition of NaTPB in the absence of palladium (three tests). 
Previous catalyst identification testing added all three intermediates at the start of testing. [Ref. $2-4,12$, 13] In this study, tests performed in support of the first objective examined both the absences of one and two of the intermediate species at the start of testing. Personnel used the time to the onset of reaction to determine the influence of the intermediates. Tests performed in support of the second objective contain elevated concentrations of each intermediate. Palladium concentration varied in these tests. Tables 1 and 2 detail both the variable and test design. For comparative purposes, these tests utilized conditions similar to earlier tests (i.e., high [NaTPB] and $55^{\circ} \mathrm{C}$ ). [Ref. 2 - 4]. See Table 3 for the target slurry composition. Experimental conditions and details for the 11 tests follow.

- All tests used sealed glass serum bottles that were nitrogen blanketed at the start of testing.

- No agitation of test vessels occurred (other than shaking at start of testing and just prior to sampling).

- All tests used a large excess of NaTPB (>6000 mg/L).

- All tests occurred at $55^{\circ} \mathrm{C}$.

- All tests contained a modified Enhanced Comprehensive Catalyst (ECC) system (see Table 4 for the modified ECC system, Reference 4 contains a list of the unmodified system).

- All tests excluded copper to reduce the rate of intermediate decomposition.

- Tests varied the initial concentration of the three intermediates (see Tables 1 and 2).

- Tests 101 through 109 added palladium at the ECC level (i.e., $2.6 \mathrm{mg} / \mathrm{L}$ ).

- All 11 tests added benzene at the ECC level (i.e., $720 \mathrm{mg} / \mathrm{L}$ ).

- Tests 110 and 111 excluded palladium.

\subsection{Set II: Excess Sodium Tetraphenylborate Testing}

The Set II. (excess NaTPB) tests included a Box-Behnken statistical design that examined the influence of temperature, palladium concentration, benzene concentration, and sodium ion concentration. Additional tests investigated the influence of different levels of excess NaTPB and other miscellaneous factors. The excess NaTPB test set investigated the rates of reaction expected over the ITP operating range for each of these four variables. Tables 6 and 7 detail the test design. See Table 5 for the target slurry compositions. Experimental conditions and detail for the 43 tests follow.

- All tests, except 229 and 230 , used sealed glass serum bottles and nitrogen blanketing at the start of testing. Tests 229 and 230 were conducted in glass reaction vessels fitted with nitrogen ventilation ports.

- All tests, except 229 and 230 , did not include agitation (other than shaking at start of testing and just prior to sampling). Tests 229 and 230 were continuously stirred.

- Tests 201 through 235 used an initial excess NaTPB target concentration of $0.01 \mathrm{M}(3400 \mathrm{mg} / \mathrm{L})$.

- Tests 236 through 239 used an initial excess NaTPB target concentration of $0.005 \mathrm{M}(1700 \mathrm{mg} / \mathrm{L})$.

- Tests 240 through 243 used an initial excess NaTPB target concentration of $0.0025 \mathrm{M}(850 \mathrm{mg} / \mathrm{L})$.

- Tests contained a modified Enhanced Comprehensive Catalyst (ECC) system (see Table 4) with $125 \mathrm{mg} / \mathrm{L}$ of each phenylborate intermediate (i.e., $3 \mathrm{~PB}, 2 \mathrm{~PB}$, and $1 \mathrm{~PB}$ ) unless otherwise noted).

- The palladium and benzene concentrations varied (see Table 6).

\subsection{Preparation and Analysis}

All tests used non-radioactive simulants. Personnel prepared test solutions from reagent grade chemicals using calibrated balances checked daily before use. [Ref. 15] The weights used for balance checks received calibration by the SRTC Standards Laboratory. The accuracy of glassware used to measure volumes was verified by gravimetric methods using water as a standard. [Ref. 16] Temperature measurements used equipment calibrated by the SRTC Standards Laboratory. Temperature monitoring occurred at least once per day to ensure a constant temperature reading within a range of $\pm 3^{\circ} \mathrm{C}$. All M\&TE used in this task received calibration or verification for accuracy prior to their use. 
With the exception of the two continuously stirred and ventilated tests, all tests occurred in sealed $160-\mathrm{mL}$ glass serum bottles with a nitrogen atmosphere. The two stirred ventilated tests used $200-\mathrm{mL}$ glass reaction vessels fitted with nitrogen inlet and outlet and a magnetic stirrer. The remaining preparations duplicated those for the other tests. Each bottle was charged with $100 \mathrm{~mL}$ of the appropriate simulant slurry followed by a prescribed amount of each of the ECC components. The soluble metal species came from stock solutions prepared from common salts. For the insoluble solids, the tests used simulated Purex sludge without noble metals, copper, silver, or mercury. All tests requiring simulated sludge and MST added hydrated species. The soluble organic species (i.e., triphenylborane (3PB), diphenylborinic acid (2PB), phenylboronic acid (1PB), phenol, isopropanol, and methanol) came from either an alkaline stock solution or pure compound. Monosodium titanate (MST), benzene, diphenylmercury, and biphenyl were added as pure compounds. After adding all potential catalysts, each vessel was sealed.

Filtrate samples were obtained for analysis by using syringe filter discs with a $0.45 \mu$ nominal pore size to remove solids from the slurry sample. Periodic analysis of the reaction mixtures occurred during the remainder of the testing. Slurry sampling occurred after aggressive, manual shaking for approximately 15 seconds. HPLC analysis of the filtrate from these samples allowed determination of the rate and extent of reaction. Personnel typically sampled once or twice a week (or less frequently in the latter part of each test). Personnel mixed solutions thoroughly prior to any liquid sampling. In all tests, liquid samples were analyzed by High Performance Liquid Chromatography (HPLC) to determine the extent of reaction. Species measured by HPLC included tetraphenylborate ion (TPB), 3PB, 2PB, 1PB, and phenol. In addition to HPLC analysis, personnel digested filtrate samples and analyzed them by Inductively Coupled Plasma - Emission Spectroscopy for soluble boron. In experiments where all excess NaTPB decomposed, researchers also analyzed filtrate samples for soluble potassium to establish the rate of KTPB decomposition under the existing test conditions. In addition, borate analysis of a filtrate sample from each test was performed by ion exclusion chromatography. The Analytical Development Section performed all chemical analyses.

\subsection{Results and Discussion}

\subsection{Set I: Intermediates Testing}

The design of intermediates test set sought primarily to identify the specific compound(s) in the group of phenylborate intermediates (i.e., 3PB, 2PB, and 1PB) that assist in the activation of palladium as a NaTPB catalyst. The test set also examined whether elevated concentrations of phenylborate intermediates would either catalyze NaTPB decomposition in the absence of palladium or accelerate the rate of palladium catalyzed NaTPB decomposition. The tests included 2 groups: eight tests for intermediates identification (Tests 101 to 108) and three tests for elevated concentration influence evaluation (Tests 109 to 111) as shown in Table 2. Appendix A (Section 9.0) provides data obtained from the tests. As noted earlier, test conditions resembled those used in previous catalyst identification testing (e.g., 4 wt \% KTPB, $2.7 \mathrm{M} \mathrm{Na}^{+}$slurry, > $6000 \mathrm{mg} / \mathrm{L}$ excess $\mathrm{NaTPB}, 55^{\circ} \mathrm{C}$, etc.).

\subsubsection{Intermediates Identification}

The intermediates identification testing consisted of eight tests. The starting mixture for the tests either included: (1) all intermediates (Test 101), (2) all but one of the intermediates (Tests 102 to 104), (3) only one of the intermediates (Tests 105 to 107), or (3) no intermediates (Test 108). As such, the design examined all combinatorial possibilities of the species relative to necessity for palladium activation.

The inclusion of all three intermediates at the start of testing (i.e., Test 101) was expected to produce the shortest induction period (i.e., time to onset of reaction). Examination of data from Test 101 (Section 9.1) indicates significant reaction began within 107 hours of testing as shown by the large increase in 3PB concentration. Note that the soluble NaTPB concentration decreases only slightly relative to the increase in 3PB concentration. This small decrease reflects the presence of insoluble NaTPB not measured by HPLC. The significant increase in soluble organic boron results from dissolution of insoluble NaTPB. 
Tests 102, 103, and 104 examined the removal of $1 P B, 2 P B$, and 3PB, respectively, from the all-inclusive mixture. In each case, significant reaction resulted within 107 hours. Tests 105, 106, and 107 added only 1PB, 2PB, or 3PB, respectively, at the start of testing. Tests 105 and 106 exhibited a significant reaction within 107 hours. While Test 107 (with only 3PB added at the start) did not exhibit significant reaction until after 197 hours, this potential difference in induction period is insufficient to draw any conclusions pertaining to the impact of $3 \mathrm{~PB}$ on induction period at this time. The most unexpected result from testing was that Test 108, with none of the three intermediates added at the start, exhibited a reactivity similar to Test 107. Earlier catalyst identification testing included a similar test (Ref. 3, Test 56) without intermediates that did not exhibit a significant NaTPB reactivity until after 321 hours. The authors can offer no reason for the lack of an induction period in the Test 108.

In summary, even in the absence of the three intermediate species, NaTPB decomposition occurs and the catalyst is activated. This information suggests that purification of existing supplies of NaTPB to remove intermediates would not prevent NaTPB decomposition in ITP.

\subsubsection{Intermediate Catalysis}

The Set I testing also attempted to determine if elevated concentrations of the intermediate species would either catalyze NaTPB decomposition in the absence of palladium or accelerate the rate of palladium catalyzed NaTPB decomposition. Three tests examined these hypotheses. Test 109 contained all three of the intermediate species at a concentration ten times greater than the nominal concentration utilized in the previous eight tests. The experiment used the nominal ECC concentration $(2.6 \mathrm{mg} / \mathrm{L})$ of palladium. Test 110 contained approximately the same concentrations of intermediates at the start as did Test 109. However, Test 110 included no palladium. Test 111 resembled Test 110 in the lack of palladium, but included much larger concentrations of $2 \mathrm{~PB}$ and $1 \mathrm{~PB}$.

Examination of the NaTPB, intermediates, and phenol data from Test 109 indicates no significant amount of NaTPB decomposition occurred. The soluble boron data indicates that some dissolution of NaTPB. However, subsequent testing indicates that a significant amount of boron leaching from the glass reaction vessels also occurred at $55^{\circ} \mathrm{C}$. The relatively stable soluble organic boron concentration supports the conclusion that only intermediates decomposed during the testing. We theorize that the elevated concentration of 3PB led to interference and coordination of the palladium thereby preventing decomposition of NaTPB. A slurry sample of Test 109 verified the presence of palladium in the test (i.e., palladium was not mistakenly omitted from the test). Tests. 110 and 111 exhibit data profiles similar to Test 109 indicating no significant amount of NaTPB decomposition. In summary, elevated concentrations of phenylborate intermediates do not catalyze the decomposition of NaTPB in the absence of palladium. Furthermore, elevated intermediate concentrations do not accelerate palladium catalyzed NaTPB decomposition. In fact, the data suggest elevated concentrations prevent palladium-catalyzed NaTPB decomposition, perhaps due to 3PB interference (i.e., coordination) with the palladium.

\subsection{Set II: Excess Sodium Tetraphenylborate Testing}

The Excess NaTPB Testing design consisted of 43 tests. The first 27 tests were a Box-Behnken statistical design addressing the influence of four variables: temperature, initial benzene concentration, sodium concentration, and palladium concentration. The remaining 16 tests examine single variable influences (e.g., stirring and ventilation, low sodium ion concentration, excess NaTPB concentration, etc.). Tables 6 and 7 summarize the test design and the variable levels.

\subsubsection{Reaction Rates}

One may calculate average reaction rates from available data by five different methods. Theoretically, the most accurate method for determining the rate of NaTPB decomposition involves measuring the change in NaTPB concentration. Unfortunately, insoluble NaTPB existed in each test and dissolved during reaction. The next method determines NaTPB decomposition rate from the rate of boron dissolution. As soluble 
NaTPB decomposes, insoluble NaTPB dissolves to maintain an equilibrated soluble NaTPB concentration. Therefore, measuring the total soluble boron concentration provides a means of measuring the amount of NaTPB that decomposed. Two sources of error exist in this method. First, the boron analytical method. introduces an error. Sampling, digestion, and analysis imparts up to $10 \%$ error. [Ref. 16]. These variances cause a random error; negated with a sufficiently large set of samples. The second error derives from boron leaching from the glass reaction vessels. Such leaching provides a systematic error (i.e., always provides a higher boron value than NaTPB decomposition alone). One can attempt to correct for this error using a measured leaching rate. Previously, Wilmarth et al. measured the leach rate from similar 160-mL borosilicate glass vessels and correlated with hydroxide concentration of similar test simulants at $45^{\circ} \mathrm{C}$. [Ref. 17] The correlation follows equation (1).

$$
\text { Rate }(\mathrm{mg} /(\mathrm{L} \cdot \mathrm{h}))=0.017\left[\mathrm{OH}^{-}\right]-0.029
$$

The authors assumed test vessels in this study at $45^{\circ} \mathrm{C}$ leached at the same rate predicted by the correlation. Since no data exists for leaching at other temperatures, the calculations conservatively assume tests at $25^{\circ} \mathrm{C}$ did not leach boron. (That assumption attributes all increases in soluble boron to a benzene-generating reaction.) Furthermore, the rate calculations assume the leaching varies linearly with temperature so that tests at $35^{\circ} \mathrm{C}$ leached at an intermediate leach rate (i.e., $50 \%$ of the above rate). The interpolated leach rate for tests that exhibited significant and measurable rates of reaction typically represented less than $10 \%$ of the measured increase in soluble boron.

The third method of calculating the rate of NaTPB reaction uses the increase in cumulative organic boron data (i.e., adding together the number of moles of boron-containing species). This method may underestimate the NaTPB decomposition rate since the data frequently lacks the final boron-containing species, borate. Failure to include borate in the cumulative value neglects any decomposition to that product. In many instances, the organic boron value decreased during the reaction.

The fourth method for calculating NaTPB decomposition rate uses the increase in 3PB concentration. This method grossly underestimates the reaction rate since $3 P B$ decomposes rapidly and the method neglects many other reactions. The authors only relied upon this method when none of the previous three methods provided a non-negative value.

The fifth, and final, method derives a rate of decomposition from the production of phenol. This method proves least accurate since the ratio of phenol produced to NaTPB decomposed can vary up to $400 \%$.

Based upon the above considerations, the authors calculated upper reaction rates from soluble boron data whenever possible. Less conservative rates came from the organic boron data. In a few instances where organic boron data did not provide a measurable reaction, but an increase in 3PB was observed, we used $3 \mathrm{~PB}$ concentration to calculate a non-conservative rate. The time period over which the bounding reaction rates was calculated was defined by the end of the induction period and the apparent exhaustion of the excess sodium tetraphenylborate (as defined by a soluble NaTPB concentration falling to a less than detectable concentration).

For comparative value, Tables 8 and 9 list benzene-generation rates calculated from soluble boron (i.e., ICP-ES) and from organic boron (i.e., HPLC), respectively. In addition, if an experiment showed an induction behavior, the tables list the length of the induction period. A review of the benzene-generation rates calculated from the ICP-ES data indicates that five of the tests showed rates equal to or greater than $7 \mathrm{mg} /(\mathrm{L} \cdot \mathrm{h}$ ). All five of these tests had the maximum palladium concentration tested (i.e., $3.6 \mathrm{mg} / \mathrm{L}$ ). Four of the five occurred at $35^{\circ} \mathrm{C}$. The next section provides a statistical analysis of the 27 tests. Nine of the 16 single effects tests also exhibited average benzene generation rates exceeding $7 \mathrm{mg} /(\mathrm{L} \cdot \mathrm{h})$. All of these contained a palladium concentration of $3.6 \mathrm{mg} / \mathrm{L}$ or greater. All of these tests occurred at $35^{\circ} \mathrm{C}$ as well. A discussion of the specific tests follows. 


\subsubsection{Statistical Analysis}

The authors performed a statistical analysis of the calculated benzene generation rate for the 27 statistically designed tests contained in Table 8 using the commercial software package JMP ${ }^{\circledR}$, from SAS Institute, Inc. [Ref. 18] Analysis indicates that reaction rates strongly correlate with total palladium concentration and temperature. Initial benzene concentration and sodium ion concentration do not correlate with the observed rates of decomposition or induction period. However, the observed induction periods showed a slight correlation with temperature. The following section discusses these findings.

\subsubsection{Comparative Analysis}

\subsubsection{Palladium Concentration}

Palladium concentration shows a correlation with the decomposition rate of NaTPB. The experimental design allows seven direct comparisons of tests with identical conditions other than the palladium concentration. The two informal tables below summarize these comparisons. The data contained in these tables come from Table 8. Examination of each comparison provides a clear conclusion that palladium concentration significantly impacts the rate of NaTPB decomposition. Those tests containing greater than $0.5 \mathrm{mg} / \mathrm{L}$ palladium and a reaction temperature equal to or greater than $35^{\circ} \mathrm{C}$ produced benzene generation rates that exceed the nominal ITP process safety limit of $7 \mathrm{mg} /(\mathrm{L} \cdot \mathrm{h})$.

\begin{tabular}{|c|c|c|}
\hline Test Comparison \& Design & \multicolumn{2}{|c|}{$\begin{array}{l}\text { Galculated Average Benzene Generation Rate }(\mathrm{mg} /(\mathrm{L} . \mathrm{h}))^{\mathrm{b}} \\
\text { Palladim Level } \\
-1(0.1 \mathrm{mg} / \mathrm{L})\end{array}$} \\
\hline 205 vs. $206(0,0,-1, P d)$ & 0.969 & 8.28 \\
\hline 207 vs. $208(0,0,1, P d)$ & 1.24 & 7.00 \\
\hline 209 vs. $210(-1,0,0, P d)$ & 0.581 & 0.894 \\
\hline 211 vs. $212(1,0,0, P d)$ & 4.09 & 19.7 \\
\hline 221 vs. $222(0,-1,0, P d)$ & 0.894 & 9.28 \\
\hline 223 vs. $224(0,1,0, P d)$ & 1.26 & 10.6 \\
\hline
\end{tabular}

aStatistical design variables listed in the order of temperature, initial benzene concentration, sodium concentration, and palladium concentration.

${ }^{b}$ Conservative rates based on soluble boron data (corrected for leaching) assuming instantaneous decomposition of one molecule NaTPB to produce four benzene molecules.

\begin{tabular}{|c|c|c|}
\hline Test Design & $\begin{array}{l}\text { Calculated Average } \\
0(0.5 \mathrm{mgl}) \\
\text { (Tests 225.226.22 }\end{array}$ & $\begin{array}{l}\text { Ion Rate } / \mathrm{mg} \text { (L) } \\
5 \times(18 \mathrm{mg} / \mathrm{L}) \\
\text { (Tests } 234,235)\end{array}$ \\
\hline$(0,0,0, P d)$ & $1.26,1.31,1.41$ & $22.4,18.3$ \\
\hline
\end{tabular}

${ }^{a}$ Statistical design variables listed in the order of temperature, initial benzene concentration, sodium concentration, and palladium concentration.

${ }^{b}$ Conservative rates based on soluble boron data (corrected for leaching) assuming instantaneous decomposition of one molecule NaTPB to produce four benzene molecules.

\subsubsection{Temperature}

Temperature also correlated with the rate of NaTPB decomposition. Data conclusively show that none of the $25^{\circ} \mathrm{C}$ tests exhibited an average benzene generation rate that exceeded the target of $7 \mathrm{mg} /(\mathrm{L} \cdot \mathrm{h})$. In fact, calculated average benzene generation for the $25^{\circ} \mathrm{C}$ tests were near or below the detection limit of 
$0.7 \mathrm{mg} /(\mathrm{L} \cdot \mathrm{h})$. Furthermore, only the test at $45^{\circ} \mathrm{C}$ and high palladium (i.e., $3.6 \mathrm{mg} / \mathrm{L}$ ) exhibited a rate greater than $7 \mathrm{mg} /(\mathrm{L} \cdot \mathrm{h})$. However, all tests at $45^{\circ} \mathrm{C}$ data exhibited measurable (i.e., significant) decomposition rates allowing little margin from the target rate. Additional insight comes from comparing the average rates observed in Tests $208,210,212,222$ and 224 . Figure 1 contains a plot of these average rates and, for comparison, rates from previous testing at 40,55 and $70^{\circ} \mathrm{C}$ [Ref. 12] for similar catalyst and sodium ion concentrations. Inspection of Figure 1 indicates, based both on the current testing and on previous testing, a significantly lower observed reaction rate at $25^{\circ} \mathrm{C}$ than anticipated. This result suggests that the test at $25^{\circ} \mathrm{C}$ exhibited an induction period for the duration of the testing.

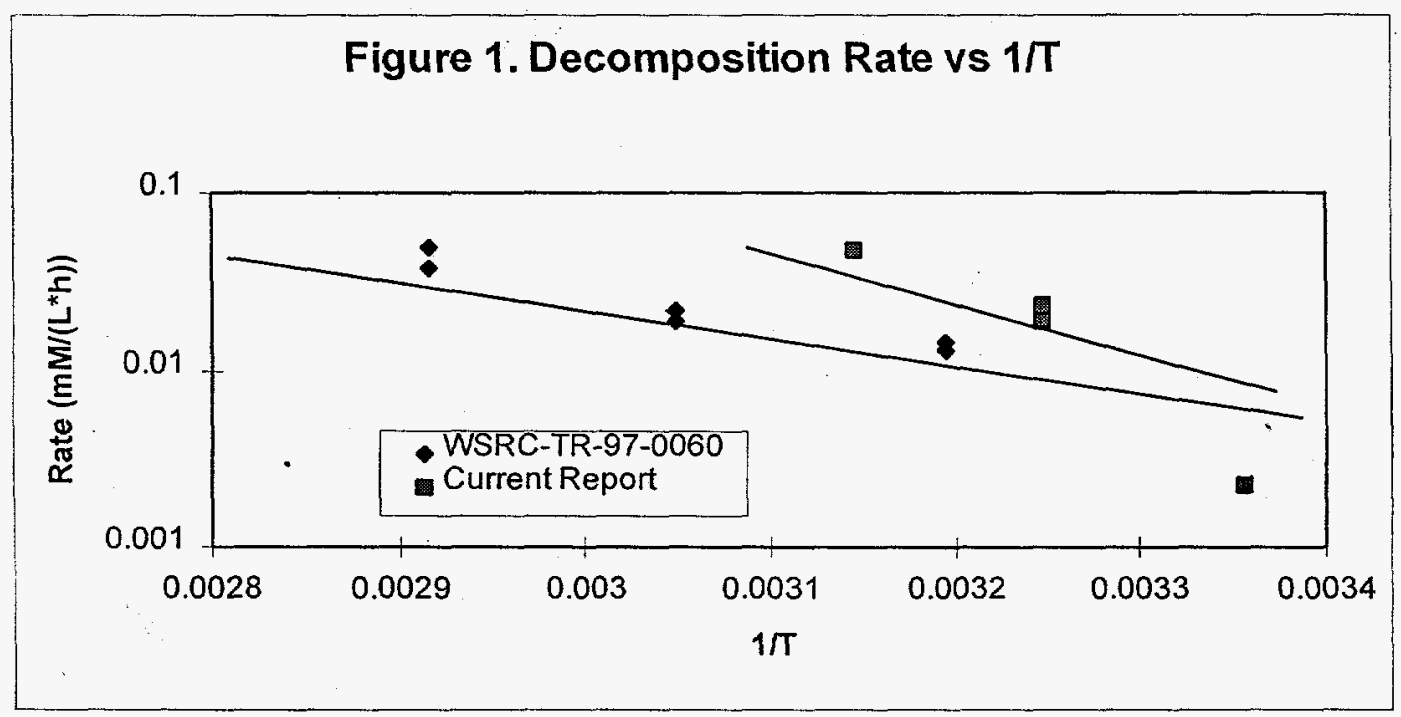

\subsubsection{Benzene Concentration}

The initial starting benzene concentration does not statistically exhibit a correlation with either the decomposition rate of NaTPB or the observed induction periods. Six direct comparisons of tests with identical design other than the starting benzene concentration exist as highlighted in the informal table below. The data contained in this table come from Table 8 . The calculated average benzene generation rates remain approximately the same within each comparative set of tests, regardless of the starting benzene level. In addition, examination of the induction periods (i.e., values contained in parentheses in the table) indicate that the majority of tests with low rates of decomposition show only a slow, steady trend in reactivity with no pronounced induction period. Note that the inclusion of the single effects test (i.e., Test 231) into the comparative set indicates that increased benzene concentration has extremely limited, if any, impact on induction period.

\begin{tabular}{|c|c|c|c|}
\hline Test Comparison \& Design: & \multicolumn{3}{|c|}{$\begin{array}{c}\text { Calculated Ay erage Benzene Generation Rate, mg/(L.h h } \\
\text { (observed induction period, } h \text { ) } \\
\text { Benzene Level }\end{array}$} \\
\hline 201 vs. $202(-1, B, 0,0)$ & $0.653(0)$ & $0.609(0)$ & \\
\hline 203 vs. $204(1, B, 0,0)$ & $4.75(0)$ & $5.66(249)$ & \\
\hline 213 vs. $215(0, B,-1,0)$ & $1.27(0)$ & $1.21(0)$ & \\
\hline 214 vs. $216(0, B, 1,0)$ & $1.28(0)$ & $1.39(0)$ & \\
\hline 221 vs. $223(0, B, 0,-1)$ & $0.894(0)$ & $1.26(0)$ & \\
\hline 222 vs. 224 vs. $231(0, B, 0,1)$ & $9.28(487)$ & $10.6(322)$ & $8.95(157)$ \\
\hline
\end{tabular}

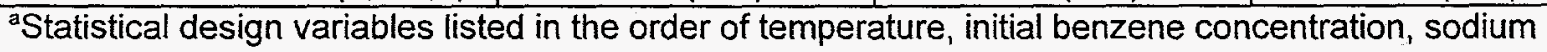
concentration, and palladium concentration.

${ }^{b}$ Conservative rates based on soluble boron data (corrected for leaching) and assuming instantaneous decomposition of one molecule NaTPB to produce four benzene molecules. 


\subsubsection{Sodium Concentration}

The sodium ion concentration of the test solution exhibited no correlation with the rate of NaTPB decomposition. Again, Table 8 gives six direct comparisons with varying sodium ion. In each case, all other variables remained constant between comparative tests as shown in the informal table below. In all but one of the comparative set of tests, the rates agree within $\sim 30 \%$ and in many of the sets yield the same value, within experimental error. In the comparison with worst agreement (Test 217 vs. Test 218), the values differed by $\sim 55 \%$. However, the range of sodium ion concentration tested was small and little difference in reactivity is expected. In fact, the one comparative set of tests that contained the single effects test (Test 233) did span an order of magnitude difference in sodium ion concentration and did exhibit a slight trend towards increased reactivity with increased sodium concentration.

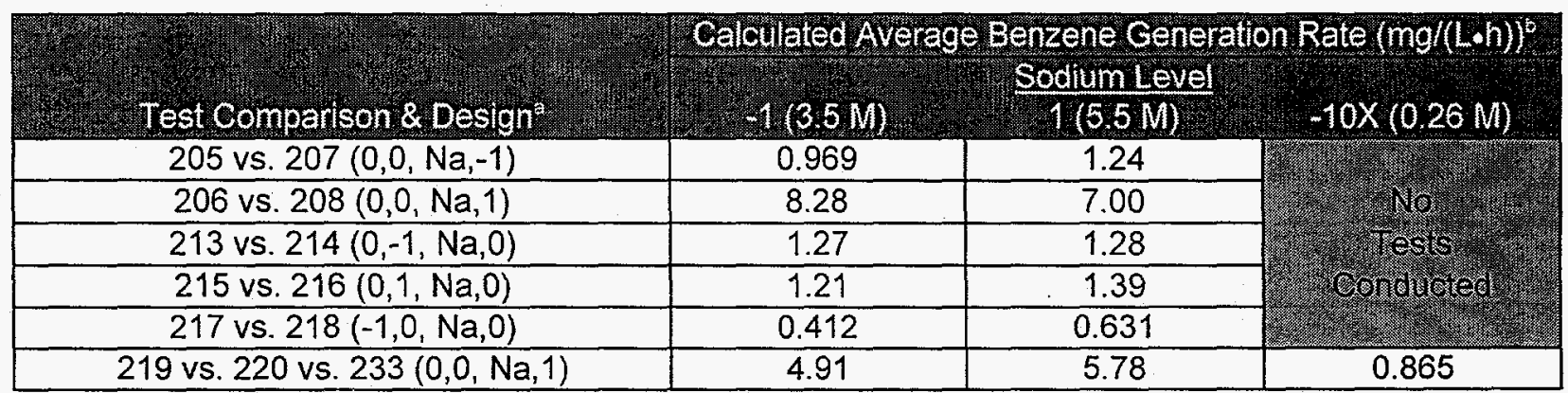

aStatistical design variables listed in the order of temperature, initial benzene concentration, sodium concentration, and palladium concentration.

bonservative rates based on soluble boron data (corrected for leaching) assuming instantaneous decomposition of one molecule NaTPB to produce four benzene molecules.

\subsubsection{Excess NaTPB Concentration}

Tests examined the influence of the quantity of excess $\mathrm{NaTPB}$ on the rate of decomposition. Under the conditions tested, the target excess NaTPB concentration in each test exceeded the solubility limit. Further analysis during testing indicated that the stock slurries used to prepare the tests contained less potassium than intended (i.e., slurries contained only $\sim 3.5 \mathrm{wt} \% \mathrm{KTPB}$ ). Subsequent analysis of the potassium hydroxide reagent used to prepare the KTPB indicated lower potassium by an equivalent amount. As a result, the amount of excess NaTPB in each test exceeded the target excess NaTPB concentration. Using this measured potassium concentration in the stock solution, we calculate the excess NaTPB concentration in these tests as $0.026 \mathrm{M}, 0.029 \mathrm{M}$, and $0.034 \mathrm{M}$. The less than $25 \%$ variance in excess NaTPB used in the tests along with the possibility of a solid phase reaction invalidated the experimental design for this objective.

Four direct comparisons of tests with identical design other than the target excess NaTPB concentration exist as shown in the informal table below. The data contained in this table come from Table 8.

Examination of each comparative set indicates negligible change in the rate of reaction.

\begin{tabular}{|c|c|c|c|}
\hline Test Comparison \& Design" & \multicolumn{3}{|c|}{$\begin{array}{c}\text { Calculated Average Benzene Generation Rate }(\mathrm{mg} /(\mathrm{L}-\mathrm{h}))^{\mathrm{b}} \\
\text { Tardet Excess NaTPB concentration }\end{array}$} \\
\hline 205 vs. 236 vs. $240(0,0,-1,-1)$ & 0.969 & 0.890 & 1.02 \\
\hline 206 vs. 237 vs. $241(0,0,-1,1)$ & 8.28 & 8.87 & 9.34 \\
\hline 207 vs. 238 vs. $242(0,0,1,-1)$ & 1.24 & 1.08 & 1.19 \\
\hline 208 vs. 239 vs. $243(0,0,1,1)$ & 7.00 & 8.50 & 8.34 \\
\hline
\end{tabular}

astatistical design variables listed in the order of temperature, initial benzene concentration, sodium concentration, and palladium concentration.

${ }^{b}$ Conservative rates based on soluble boron data (corrected for leaching) assuming instantaneous decomposition of one molecule NaTPB to produce four benzene molecules.

\subsubsection{Agitation and Ventilation}

The last set of single effects tests examined the influence of continuous stirring and ventilation on both the induction period and rates of reaction. Previous testing [Ref. 3] showed benzene as required to facilitate palladium catalyzed NaTPB decomposition. Speculation centered on the possible correlation of benzene 
concentration with the observed induction periods. If such a correlation exists, continuous agitation and ventilation would limit benzene accumulation in the test vessels and prevent activation of the palladium catalyst system (i.e., the tests would never overcome the induction period due to a lack of benzene). Testing included two continuously stirred and nitrogen ventilated tests and two sealed, static tests with other test conditions (e.g., temperature, palladium, etc.) identical. The informal table below provides comparisons. The data contained in this table come from Table 8. Examination indicates that the continuous stirring and nitrogen ventilation do not prevent the palladium catalyzed NaTPB decomposition. The rates of decomposition are similar in the four tests. Suprisingly, continuous stirring and nitrogen ventilation appears to shorten the observed induction period. This finding may reflect more anoxic conditions present in the continuously ventilated tests than in the sealed static tests.

\begin{tabular}{|c|c|c|c|}
\hline Test \# \& Design & Test Method & $\begin{array}{l}\text { Calculated } \\
\text { Average Benzene } \\
\text { Generation Rate } \\
\text { (mol(L) })^{b}\end{array}$ & $\begin{array}{l}\text { Observed } \\
\text { Induction Period } \\
(h)\end{array}$ \\
\hline $222(0,-1,0,1)$ & unagitated and not ventilated & 9.28 & 487 \\
\hline $228(0,-1,0,1)$ & unagitated and not ventilated & 10.1 & 322 \\
\hline $229(0,-1,0,1)$ & continuously stirred and ventilated & 10.0 & 141 \\
\hline $230(0,-1,0,1)$ & continuously stirred and ventilated & 6.25 & 141 \\
\hline
\end{tabular}

astatistical design variables listed in the order of temperature, initial benzene concentration, sodium concentration, and palladium concentration.

${ }^{b}$ Conservative rates are based on soluble boron data (corrected for leaching) assuming instantaneous decomposition of one molecule NaTPB to produce four benzene molecules.

\subsection{Conclusions}

The stability of excess amounts of sodium tetraphenylborate (NaTPB) in the In-Tank Precipitation (ITP) facility depends on a number of variables. Concentration of palladium, initial benzene, and sodium ion as well as temperature provide the best opportunities for controlling the decomposition rate. This study examined the influence of these four variables on the reactivity of palladium-catalyzed sodium tetraphenylborate decomposition. Also, single effects tests investigated the reactivity of simulants with continuous stirring and nitrogen ventilation, with very high benzene concentrations, under washed sodium concentrations, with very high palladium concentrations, and with minimal quantities of excess NaTPB. These tests showed the following.

The testing demonstrates that current facility configuration does not provide assured safety of operations relative to the hazards of benzene (in particular to maintain the tank headspace below $60 \%$ of the lower flammability limit ( $(\mathrm{fl})$ for benzene generation rates of greater than $7 \mathrm{mg} /(\mathrm{L} \cdot \mathrm{h}))$ from possible accelerated reaction of excess NaTPB. Current maximal operating temperatures of $40^{\circ} \mathrm{C}$ and the lack of protection against palladium entering Tank $48 \mathrm{H}$ provide insufficient protection against the onset of the reaction. Similarly, control of the amount of excess NaTPB, purification of the organic, or limiting the benzene content of the slurry (via stirring) and ionic strength of the waste mixture prove inadequate to assure safe operation.

- Tests at $45^{\circ} \mathrm{C}$ exhibited decomposition rates that might be too large to provide significant margin to maintain the tank headspace below $60 \%$ of the LFL of the tank.

- All $25^{\circ} \mathrm{C}$ tests exhibited an average calculated benzene generation rate below the target of $7 \mathrm{mg} /(\mathrm{L} \cdot \mathrm{h})$. Analysis of the temperature data indicates that the catalyst apparently did not activate at $25^{\circ} \mathrm{C}$ during the test period.

- Only tests containing greater than $0.5 \mathrm{mg} / \mathrm{L}$ palladium and at temperatures equal to or greater than $35^{\circ} \mathrm{C}$ produced calculated benzene generation rates exceeding the target of $7 \mathrm{mg} /(\mathrm{L} \cdot \mathrm{h})$. 
- Diluting the sodium concentration in the starting waste mixture to $3.5 \mathrm{M}$ does not significantly effect the generation rate of benzene.

- Initial benzene concentration does not statistically correlate with either the decomposition rate of NaTPB or the observed induction period.

- Rapid decomposition of NaTPB, in the presence of palladium, occurs even without added initial concentrations of three phenylborate byproducts (i.e., in the absence of intermediates at the start of testing, NaTPB decomposition by a mechanism other than palladium catalysis produces a small, yet sufficient, concentration of intermediates). This result indicates purification of existing supplies of NaTPB to remove intermediates would not prevent NaTPB decomposition in ITP.

The experimental design also attempted to provide insight into the reaction mechanism by examining the dependence of the reaction on the presence of phenylborate byproducts, temperature, palladium concentration, and benzene content.

- Elevated concentrations of phenylborate intermediates do not accelerate the decomposition rate of NaTPB for either the palladium-catalyzed reaction or the reaction absent palladium.

- The presence of any one of the three intermediates -- phenylboronic acid (1PB), diphenylborinic acid (2PB), or triphenylborane (3PB) -- will activate palladium-catalyzed NaTPB decomposition.

- For tests that showed measurable reaction, the induction period varied from 0 to 487 hours. Only one reactive system - at $45^{\circ} \mathrm{C}$ with high palladium -- showed no induction period.

- Sodium tetraphenylborate decomposition rates and length of induction periods correlate with temperature (i.e., a trend was observed that relatively fast reactions and short induction periods were observed at $45^{\circ} \mathrm{C}$, lower rates and longer induction periods were observed at $35^{\circ} \mathrm{C}$, and very low rates due to the lack of catalyst activation (extremely long or infinite induction periods) was observed at $25^{\circ} \mathrm{C}$.

- Sodium tetraphenylborate decomposition rates correlate with total palladium concentration.

During the current testing, induction periods ranged from 90 to more than 3800 hours. In addition, variables previously identified to influence the duration of the induction period showed limited impact under the conditions tested. These results indicate a significant uncertainty in the parameters that influence the duration of the induction period. Future testing should aim at resolving these uncertainties.

\subsection{Acknowledgments}

The authors would like to thank the individuals who contributed to this program. Kim Wyszynski and Shirley McCollum performed tireless assistance in conducting the experiments. Laura Tovo, Joe Clymire, Charles Coleman, Amy Eckwechuku and Anne (Tom Whites' analyst) provided exceptional and timely analytical support. The authors would also like to thank Douglas Walker, William Wilmarth, Charles Crawford, David Hobbs, Russell Eibling, Bill Wilmarth, Samuel Fink, Walter Tamosaitis, Paul Rutland, John Fowler, Roy Jacobs, and Joe Carter for their diligent support, encouragement, and insight.

\subsection{References}

1. D. D. Walker, M. J. Barnes, C. L. Crawford, R. F. Swingle, R. A. Peterson, M. S. Hay, and S. D. Fink, "Decomposition of Tetraphenylborate in Tank 48H (U)", WSRC-TR-96-0113, Rev. 0, May 10, 1996.

2. M. J. Barnes and R. A. Peterson, "Sodium Tetraphenylborate Catalyst Identification: Phase A Statistical Design Studies (U)", WSRC-TR-97-0210, Rev. 0, July 22, 1997. 
3. M. J. Barnes and R. A. Peterson, "Sodium Tetraphenylborate Catalyst Identification: Phase B and C Statistical Design Studies (U)”, WSRC-TR-97-0230, Rev. 0, August 13, 1997.

4. M. J. Barnes, "Sodium Tetraphenylborate Catalyst Identification: Phase D Statistical Design Studies (U)", WSRC-TR-97-0275, Rev. 0, September 5, 1997.

5. M. J. Barnes, "Decomposition of Sodium Tetraphenylborate (U)", WSRC-RP-90-465, May 10, 1990.

6. M. J. Barnes, "Sodium Tetraphenylborate Solution Stability - A Long Term Study (U)", WSRC-RP-92-786, June 11, 1992.

7. M. J. Barnes and T. B. Edwards, "Copper Catalyzed Sodium Tetraphenylborate Decomposition Studies (U)", WSRC-TR-96-0351, November 7, 1996.

8. C. L. Crawford and R. A. Peterson, "Decomposition Studies of Triphenylboron, Diphenylborinic Acid and Phenylboronic Acid in Aqueous Alkaline Solutions Containing Copper (U)", WSRC-TR-97-0045, February 11, 1997.

9. W. R. Wilmarth, C. L. Crawford, and R. A. Peterson, "Copper-Catalyzed Decomposition of Diphenylborinic Acid and Phenylboronic Acid (U)", WSRC-TR-97-0238, August 29, 1997.

10. "Department of Energy Implementation Plan for Defense Nuclear Facilities Safety Board Recommendation 96-1 to the Secretary of Energy", In-Tank Precipitation Facility at the Savannah River Site, October 1996.

11. P. L. Rutland, "Excess Sodium TPB Decomposition", HLE-TTR-98038, March 11, 1998.

12. M. J. Barnes, C. L. Crawford, and C. A. Nash, "Sodium Tetraphenylborate Catalyst Identification: Preliminary Studies Set 1 (U)", WSRC-TR-97-0060, Rev. 0, March 6, 1997.

13. M. J. Barnes, "Sodium Tetraphenylborate Catalyst Identification: Preliminary Studies Set 2 (U)", WSRC-TR-97-0144, Rev. 0, March 6, 1997.

14. D. D. Walker, "Balance Check" (U), Manual L12.1, Procedure IWT-OP-011, Rev. 3, December 6, 1994.

15. D. D. Walker, "Calibration of Laboratory Glassware" (U), Manual L12.1, Procedure IWT-OP-009, Rev. 3, May 8, 1995.

16. Personal communication from L. Tovo.

17. W. R. Wilmarth, C. L. Crawford, T. L. White, and J. W. Clymire, "Kinetic Studies of Inhibitor Agents for the Decomposition of Sodium Tetraphenylborate", WSRC-TR-98-Draft in preparation.

18. SAS Institute, JMP ${ }^{\circledR}$ Statistics and Graphics Guide, Version 3, SAS Institute, Inc., Cary, NC, 1994. 


\subsection{Tables}

Table 1. Set I (Intermediates) decomposition study variable design.

\begin{tabular}{|c|c|c|c|c|}
\hline \multirow{2}{*}{ Variable } & -1 & 1 & $10 \times 1$ & $32 \times 1$ \\
\cline { 2 - 5 } & -1 & 125 & 1250 & 4000 \\
\hline 3PB (mg/L) & 0 & 125 & 1250 & 4000 \\
\hline 2PB (mg/L) & 0 & 125 & 1250 & not tested $^{2}$ \\
\hline TPB $(\mathrm{mg} / \mathrm{L})$ & 0 &
\end{tabular}

${ }^{2}$ The $32 \times 13$ PB level not tested due to the dilution that would result.

Table 2. Set I (Intermediates) decomposition study test design.

\begin{tabular}{|c|c|c|c|c|}
\hline Test \# & 3PB & 2PB & 1PB & Description \\
\hline 101 & 1 & 1 & 1 & all 3 added \\
\hline 102 & 1 & $T$ & -1 & \multirow{3}{*}{2 added } \\
\hline 103 & 1 & -1 & 1 & \\
\hline 104 & -1 & 1 & 1 & \\
\hline 105 & -1 & -1 & $T$ & \multirow{3}{*}{ only 1 added } \\
\hline 106 & -1 & 1 & -1 & \\
\hline 707 & 1 & -1 & -1 & \\
\hline 108 & -1 & -1 & -1 & none added \\
\hline 109 & $10 \times 1$ & $10 \times 1$ & $10 \times 1$ & \\
\hline 710 & $10 \times 1$ & $10 \times 1$ & $10 \times 1$ & palladium not addec \\
\hline Tन1 & $10 \times 1$ & $32 \times 1$ & $32 \times 1$ & palladium not addec \\
\hline
\end{tabular}

Table 3. Target simulant composition for intermediates decomposition studies.

\begin{tabular}{|c|c|}
\hline Component & $\begin{array}{c}\text { Standard Slurry } \\
\text { Concentration }\end{array}$ \\
\hline Sodium & $2.7 \mathrm{M}$ \\
\hline hydroxide & $1.60 \mathrm{M}$ \\
\hline nitrite & $0.38 \mathrm{M}$ \\
\hline nitrate & $0.37 \mathrm{M}$ \\
\hline aluminate & $0.092 \mathrm{M}$ \\
\hline sulfate & $0.005 \mathrm{M}$ \\
\hline carbonate & $0.10 \mathrm{M}$ \\
\hline chloride & $0.008 \mathrm{M}$ \\
\hline fluoride & $0.004 \mathrm{M}$ \\
\hline phosphate & $0.003 \mathrm{M}$ \\
\hline TPB & $0.02-0.03 \mathrm{M}$ \\
\hline NaTPB (insoluble) & $\sim 0 \mathrm{~g} / \mathrm{L}$ \\
\hline KTPB (insoluble) & $46 \mathrm{~g} / \mathrm{L}(\sim 4 \mathrm{Wt} \%)$ \\
\hline
\end{tabular}


Table 4. Modified Enhanced Comprehensive Catalyst (ECC) composition with target concentrations provided in parentheses.

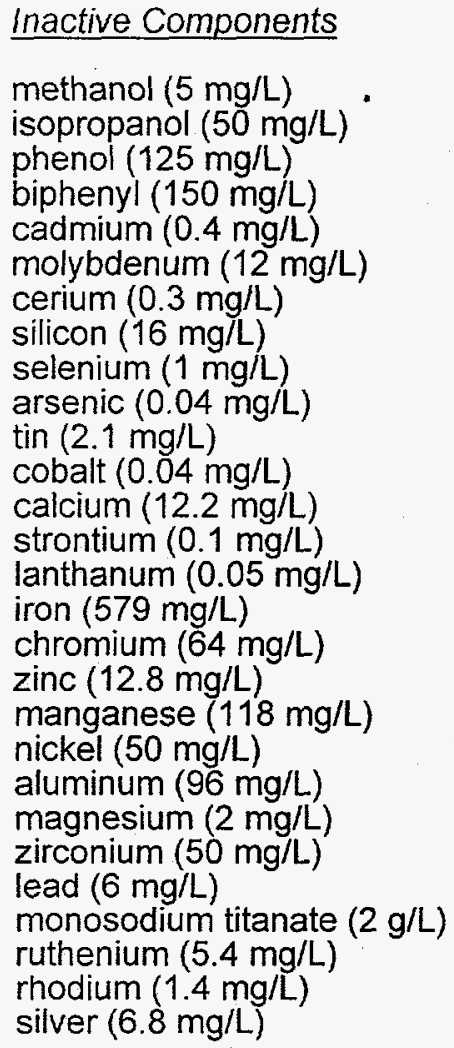

Table 5. Target simulant composition for Set ll (excess NaTPB) decomposition studies.

\begin{tabular}{|c|c|c|c|c|}
\hline Component & $\begin{array}{c}\text { Washed } \mathrm{Na}^{+} \\
\text {Slurry } \\
\text { Concentration }\end{array}$ & $\begin{array}{l}3.5 \mathrm{M} \mathrm{Na}^{+} \text {Slurry } \\
\text { Concentration }\end{array}$ & $\begin{array}{l}4.5 \mathrm{M} \mathrm{Na}^{+} \text {Slurry } \\
\text { Concentration }\end{array}$ & $\begin{array}{l}5.5 \mathrm{M} \mathrm{Na}^{+} \text {Slurry } \\
\text { Concentration }\end{array}$ \\
\hline sodium & $0.26 \mathrm{M}$ & $3.5 \mathrm{M}$ & $4.5 \mathrm{M}$ & $5.5 \mathrm{M}$ \\
\hline hydroxide & $0.15 \mathrm{M}$ & $2.0 \mathrm{M}$ & $2.60 \mathrm{M}$ & $3.3 \mathrm{M}$ \\
\hline nitrite & $0.04 \mathrm{M}$ & $0.50 \mathrm{M}$ & $0.65 \mathrm{M}$ & $0.80 \mathrm{M}$ \\
\hline nitrate & $0.04 \mathrm{M}$ & $0.49 \mathrm{M}$ & $0.64 \mathrm{M}$ & $0.79 \mathrm{M}$ \\
\hline aluminate & $0.01 \mathrm{M}$ & $0.12 \mathrm{M}$ & $0.16 \mathrm{M}$ & $0.19 \mathrm{M}$ \\
\hline sulfate & $0.001 \mathrm{M}$ & $0.007 \mathrm{M}$ & $0.009 \mathrm{M}$ & $0.011 \mathrm{M}$ \\
\hline carbonate & $0.01 \mathrm{M}$ & $0.14 \mathrm{M}$ & $0.18 \mathrm{M}$ & $0.22 \mathrm{M}$ \\
\hline chloride & $0.001 \mathrm{M}$ & $0.010 \mathrm{M}$ & $0.013 \mathrm{M}$ & $0.016 \mathrm{M}$ \\
\hline fluoride & $0.001 \mathrm{M}$ & $0.006 \mathrm{M}$ & $0.007 \mathrm{M}$ & $0.009 \mathrm{M}$ \\
\hline phosphate & $0.0007 \mathrm{M}$ & $0.004 \mathrm{M}$ & $0.006 \mathrm{M}$ & $0.007 \mathrm{M}$ \\
\hline Excess NaTPB & \multicolumn{4}{|c|}{$0.01 \mathrm{M}(3400 \mathrm{mg} / \mathrm{L})$ unless otherwise noted for a specific test } \\
\hline RTPB (insoluble) & $42 \mathrm{~g} / \mathrm{L}(-4 \mathrm{wt} \%)$ & $47 \mathrm{~g} / \mathrm{L}(-4 \mathrm{wt} \%)$ & $49 g / L(\sim 4 w t \%)$ & $51 \mathrm{~g} / \mathrm{L}(\sim 4 \mathrm{wt} \%)$ \\
\hline
\end{tabular}

Table 6. Set II (Excess NaTPB) decomposition study variable design.

\begin{tabular}{|c|c|c|c|}
\hline \multirow{2}{*}{ Variable } & \multicolumn{3}{|c|}{ Level } \\
\cline { 2 - 4 } & -1 & 0 & 1 \\
\hline Temperature $\left({ }^{\circ} \mathrm{C}\right)$ & 25 & 35 & 45 \\
\hline$\left[\mathrm{Benzene}^{\circ}(\mathrm{mg} / \mathrm{L})\right.$ & 0 & 200 & 400 \\
\hline$\left[\mathrm{Na}^{+}\right](\mathrm{M})$ & 3.5 & 4.5 & 5.5 \\
\hline$[\mathrm{Pd}](\mathrm{mg} / \mathrm{L})$ & 0.1 & 0.5 & 3.6 \\
\hline
\end{tabular}


Table 7. Set II (Excess NaTPB) decomposition study test design.

\begin{tabular}{|c|c|c|c|c|c|}
\hline Test \# & Temperature & Benzene & $\mathrm{Na}^{+}$ & palladium & Description \\
\hline 201 & -1 & -1 & 0 & 0 & \\
\hline 202 & -1 & 1 & 0 & 0 & \\
\hline 203 & 1 & -1 & 0 & 0 & \\
\hline 204 & 1 & 1 & 0 & 0 & \\
\hline 205 & 0 & 0 & -1 & -1 & \\
\hline 206 & 0 & $\overline{0}$ & -1 & 1 & \\
\hline 207 & 0 & 0 & 1 & -1 & \\
\hline 208 & 0 & 0 & 1 & 1 & \\
\hline 209 & -1 & 0 & 0 & -1 & \\
\hline 210 & -1 & 0 & 0 & 1 & \\
\hline 211 & 1 & 0 & 0 & -1 & \\
\hline 212 & 1 & 0 & 0 & 1 & \\
\hline 213 & 0 & -1 & -1 & 0 & \\
\hline 214 & 0 & -1 & 1 & 0 & \\
\hline 215 & 0 & 1 & -1 & 0 & \\
\hline 216 & 0 & 1 & 1 & 0 & \\
\hline 217 & -1 & 0 & -1 & 0 & \\
\hline 218 & -1 & 0 & 1 & 0 & \\
\hline 219 & 1 & 0 & -1 & 0 & \\
\hline 220 & 1 & 0 & 1 & 0 & \\
\hline 221 & 0 & -1 & 0 & -1 & \\
\hline 222 & $\overline{0}$ & -1 & 0 & 1 & \\
\hline 223 & $\overline{0}$ & 1 & 0 & -1 & \\
\hline 224 & 0 & 1 & 0 & 1 & \\
\hline 225 & 0 & 0 & 0 & $\overline{0}$ & \\
\hline 226 & 0 & 0 & 0 & 0 & \\
\hline 227 & 0 & $\overline{0}$ & 0 & 0 & \\
\hline 2. & 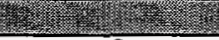 & 5 - & 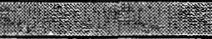 & $\sqrt{25}$ & \\
\hline 228 & 0 & -1 & 0 & 1 & duplicate of \# 222 \\
\hline 229 & $\overline{0}$ & -1 & $\overline{0}$ & 1 & stirred \& \\
\hline 230 & 0 & -1 & 0 & 1 & ventilateda \\
\hline 231 & 0 & $10 \times 10$ & 0 & 1 & $4000 \mathrm{mg} / \mathrm{L}$ benzene \\
\hline 232 & $\overline{0}$ & 0 & washed $\mathrm{Na}^{+\mathrm{C}}$ & -1 & Compare to \\
\hline 233 & 0 & 0 & washed $\mathrm{Na}^{+}$ & 1 & $\# 205-208$ \\
\hline 234 & 0 & $\overline{0}$ & 0 & $5 \times 1^{d}$ & increased Pd \& sludge, \\
\hline 235 & 0 & 0 & 0 & $5 \times 1$ & compare to \# $225-227$ \\
\hline 236 & 0 & $\overline{0}$ & -1 & -1 & use $0.005 \mathrm{M} \mathrm{NaTPB}$ \\
\hline 237 & 0 & 0 & -1 & 1 & compare w/ \\
\hline 238 & 0 & 0 & 1 & -1 & $\# 205-208 \&$ \\
\hline 239 & $\overline{0}$ & 0 & 1 & 1 & $240-243^{e}$ \\
\hline 240 & 0 & 0 & -1 & -1 & use $0.0025 \mathrm{M} \mathrm{NaTPB}$, \\
\hline 241 & 0 & 0 & -1 & 1 & compare wl \\
\hline 242 & 0 & 0 & 1 & -1 & $\# 205-208 \&$ \\
\hline 243 & 0 & 0 & 1 & 1 & $236-239^{f}$ \\
\hline
\end{tabular}

Tests 229 and 230 use $200-\mathrm{mL}$ glass reactors, each confinuously stirred with the vapor space purged by a continuous flow of nitrogen $(\sim 60 \mathrm{~mL} / \mathrm{min})$.

b $10 \times 1$ indicates benzene added to Test 231 at a target concentration of $4000 \mathrm{mg} / \mathrm{L}$.

'Tests 232 and 233 use a washed sodium ion concentration (see Table 7)

$\mathrm{d} 5 \mathrm{x} 1$ indicates palladium added to Tests 234 and 235 at a target concentration of $13 \mathrm{mg} / \mathrm{L}$.

eTests 236 through 239 use slurries with an initial excess NaTPB target concentration of

$0.005 \mathrm{M}(1700 \mathrm{mg} / \mathrm{L})$.

'Tests 240 through 243 use slurries with an initial excess NaTPB target concentration of $0.0025 \mathrm{M}$ (850 mg/L). 
Table 8. Excess sodium tetraphenylborate studies' average benzene generation rates (conservative) calculated from soluble boron data (corrected).

\begin{tabular}{|c|c|c|c|}
\hline Test \# & $\begin{array}{c}\text { Statistical } \\
\text { Design } \\
\left.\text { (Temp., Benzene, } \mathrm{Na}^{+}, \mathrm{Pd}\right)\end{array}$ & $\begin{array}{c}\text { Calculated } \\
\text { Average Benzene } \\
\text { Generation Rate } \\
(\mathrm{mg} /(\mathrm{L} \cdot \mathrm{h}))^{\mathrm{a}}\end{array}$ & $\begin{array}{l}\text { Induction } \\
\text { Period } \\
\text { (h) }\end{array}$ \\
\hline 201 & $(-1,-1,0,0)$ & 0.653 & \\
\hline 202 & $(-1,1,0,0)$ & 0.609 & \\
\hline 203 & $(1,-1,0,0)$ & 4.75 & \\
\hline 204 & $(1,1,0,0)$ & 5.66 & \\
\hline 205 & $(0,0,-1,-1)$ & 0.969 & \\
\hline 206 & $(0,0,-1,1)$ & 8.28 & 90 \\
\hline 207 & $(0,0,1,-1)$ & 1.24 & \\
\hline 208 & $(0,0,1,1)$ & 7.00 & 157 \\
\hline 209 & $(-1,0,0,-1)$ & 0.581 & \\
\hline 210 & $(-1,0,0,1)$ & 0.894 & \\
\hline 211 & $(1,0,0,-1)$ & 4.09 & 301 \\
\hline 212 & $(1,0,0,1)$ & 19.7 & \\
\hline 213 & $(0,-1,-1,0)$ & 1.27 & \\
\hline 214 & $(0,-1,1,0)$ & 7.28 & \\
\hline 215 & $(0,1,-1,0)$ & 1.21 & \\
\hline 216 & $(0,1,1,0)$ & 1.39 & \\
\hline 217 & $(-1,0,-1,0)$ & 0.412 & \\
\hline 218 & $(-1,0,1,0)$ & 0.631 & \\
\hline 219 & $(1,0,-1,0)$ & 4.91 & \\
\hline 220 & $(1,0,1,0)$ & 5.78 & 413 \\
\hline 221 & $(0,-1,0,-1)$ & 0.894 & \\
\hline 222 & $(0,-1,0,1)$ & 9.28 & 487 \\
\hline 223 & $(0,1,0,-1)$ & 1.26 & \\
\hline 224 & $(0,1,0,1)$ & 10.6 & 322 \\
\hline 225 & $(0,0,0,0)$ & 1.26 & \\
\hline 226 & $(0,0,0,0)$ & 1.31 & \\
\hline 227 & $(0,0,0,0)$ & 1.41 & \\
\hline 20 & & & \\
\hline 228 & $(0,-1,0,1)$ & 10.1 & 322 \\
\hline 229 & $(0,-1,0,1)$ & 10.0 & 141 \\
\hline 230 & $(0,-1,0,1)$ & 6.25 & 141 \\
\hline 231 & $(0,10 \times, 0,1)$ & 8.95 & 157 \\
\hline 232 & $(0,0,-10 x,-1)$ & 0.547 & \\
\hline 233 & $(0,0,-10 \times, 1)$ & 0.865 & \\
\hline 234 & $(0,0,0,5 X)$ & 22.4 & 249 \\
\hline 235 & $(0,0,0,5 X)$ & 18.3 & 249 \\
\hline 236 & $(0,0,-1,-1)$ & 0.890 & \\
\hline 237 & $(0,0,-1,1)$ & 8.87 & 157 \\
\hline 238 & $(0,0,1,-1)$ & 1.08 & \\
\hline 239 & $(0,0,1,1)$ & 8.50 & 157 \\
\hline 240 & $(0,0,-1,-1)$ & 1.02 & \\
\hline 241 & $(0,0,-1,1)$ & 9.34 & 157 \\
\hline 242 & $(0,0,1,-1)$ & 1.19 & \\
\hline 243 & $(0,0,1,1)$ & 8.34 & 157 \\
\hline
\end{tabular}

Assumes instantaneous decomposition of one molecule NaTPB to produce four benzene molecules. 
Table 9. Excess sodium tetraphenylborate studies' average benzene generation rates (nonconservative) calculated from organic boron data.

\begin{tabular}{|c|c|c|c|}
\hline Test \# & $\begin{array}{c}\text { Statistical } \\
\text { Design } \\
\left.\text { (Temp., Benzene, } \mathrm{Na}^{+}, \mathrm{Pd}\right)\end{array}$ & $\begin{array}{c}\text { Calculated } \\
\text { Average Benzene } \\
\text { Generation Rate } \\
(\mathrm{mg} /(\mathrm{L} \cdot \mathrm{h}))^{\mathrm{a}}\end{array}$ & $\begin{array}{l}\text { Induction } \\
\text { Period } \\
\text { (h) }\end{array}$ \\
\hline 201 & $(-1,-1,0,0)$ & 0 & \\
\hline 202 & $(-1,1,0,0)$ & 0 & \\
\hline 203 & $(1,-1,0,0)$ & 0 & \\
\hline 204 & $(1,1,0,0)$ & $0.625^{\circ}$ & 249 \\
\hline 205 & $(0,0,-1,-1)$ & 0 & \\
\hline 206 & $(0,0,-1,1)$ & 7.25 & 90 \\
\hline 207 & $(0,0,1,-1)$ & 0 & \\
\hline 208 & $(0,0,1,1)$ & 4.47 & 157 \\
\hline 209 & $(-1,0,0,-1)$ & 0 & \\
\hline 210 & $(-1,0,0,1)$ & 0 & \\
\hline 211 & $(1,0,0,-1)$ & $0.106^{\circ}$ & 301 \\
\hline 212 & $(1,0,0,1)$ & 8.84 & \\
\hline 213 & $(0,-1,-1,0)$ & 0 & \\
\hline 214 & $(0,-1,1,0)$ & 0 & \\
\hline 215 & $(0,1,-1,0)$ & 0 & \\
\hline 216 & $(0,1,1,0)$ & 0 & \\
\hline 217 & $(-1,0,-1,0)$ & 0 & \\
\hline 218 & $(-1,0,1,0)$ & 0 & \\
\hline 219 & $(1,0,-1,0)$ & 0 & \\
\hline 220 & $(1,0,1,0)$ & $0.975^{\circ}$ & 413 \\
\hline 221 & $(0,-1,0,-1)$ & 0 & \\
\hline 222 & $(0,-1,0,1)$ & 5.69 & 487 \\
\hline 223 & $(0,1,0,-1)$ & 0 & \\
\hline 224 & $(0,1,0,1)$ & 4.31 & 322 \\
\hline 225 & $(0,0,0,0)$ & 0 & \\
\hline 226 & $(0,0,0,0)$ & 0 & \\
\hline 227 & $(0,0,0,0)$ & 0 & \\
\hline 90.07 & $2 \sqrt{2.16}$ & 2 & \\
\hline 228 & $(0,-1,0,1)$ & 5.87 & 322 \\
\hline 229 & $(0,-1,0,1)$ & 0 & \\
\hline 230 & $(0,-1,0,1)$ & 0 & \\
\hline 231 & $(0,10 \times, 0,1)$ & 4.28 & 157 \\
\hline 232 & $(0,0,-10 X,-1)$ & 0 & \\
\hline 233 & $(0,0,-10 \times, 1)$ & $0.384^{\circ}$ & 487 \\
\hline 234 & $(0,0,0,5 X)$ & 5.56 & 249 \\
\hline 235 & $(0,0,0,5 X)$ & 4.94 & 249 \\
\hline 236 & $(0,0,-1,-1)$ & 0 & \\
\hline 237 & $(0,0,-1,1)$ & 4.37 & 157 \\
\hline 238 & $(0,0,1,-1)$ & 0 & \\
\hline 239 & $(0,0,1,1)$ & 4.87 & 157 \\
\hline 240 & $(0,0,-1,-1)$ & 0 & \\
\hline 241 & $(0,0,-1,1)$ & 3.44 & 157 \\
\hline 242 & $(0,0,1,-1)$ & 0 & \\
\hline 243 & $(0,0,1,1)$ & 5.03 & 157 \\
\hline
\end{tabular}

assumes instantaneous decomposition of one molecule NaTPB to produce four benzene molecules. ${ }^{b}$ Average benzene generation rates calculated from $3 \mathrm{~PB}$ data. 


\subsection{Appendix A - Intermediates' Studies Test Data}

\subsection{Data from Test 101}

\begin{tabular}{|c|c|c|c|c|c|c|c|}
\hline $\begin{array}{l}\text { Reaction } \\
\text { Time (h) }\end{array}$ & $\begin{array}{l}\text { Soluble } \\
\text { NaTPB } \\
\text { (mmol/L) }\end{array}$ & $\begin{array}{c}\text { 3PB } \\
(\mathrm{mmol} / \mathrm{L})\end{array}$ & $\begin{array}{c}2 \mathrm{~PB} \\
(\mathrm{mmol} / \mathrm{L})\end{array}$ & $\begin{array}{c}1 \mathrm{~PB} \\
(\mathrm{mmol} / \mathrm{L})\end{array}$ & $\begin{array}{l}\text { Phenol } \\
\text { (mmol/L) }\end{array}$ & $\begin{array}{l}\text { Soluble } \\
\text { Boron } \\
\text { (mmol/L) }\end{array}$ & $\begin{array}{c}\text { Soluble } \\
\text { Organic } \\
\text { Boron } \\
\text { (mmol/L) }\end{array}$ \\
\hline 15 & 22.4 & 1.07 & 0.60 & 0.94 & 1.51 & 22.4 & 25.0 \\
\hline 37 & 21.0 & 1.51 & 0.58 & 0.98 & 1.53 & 23.2 & 24.1 \\
\hline 107 & 18.7 & 9.38 & 1.73 & 1.79 & 2.42 & 31.5 & 31.6 \\
\hline 177 & 18.0 & 12.15 & 2.54 & 1.44 & 1.94 & 35.3 & 34.1 \\
\hline 268 & 17.0 & 14.24 & 4.58 & 1.84 & 2.02 & 42.8 & 37.6 \\
\hline 434 & 13.7 & 14.88 & 5.30 & 4.09 & 3.30 & 46.9 & 38.0 \\
\hline 600 & 9.6 & 17.03 & 6.79 & 5.14 & 2.90 & 48.8 & 38.6 \\
\hline 767 & 6.6 & 17.31 & 7.37 & 5.21 & 3.56 & 53.7 & 36.5 \\
\hline
\end{tabular}

\subsection{Data from Test 102}

\begin{tabular}{|c|c|c|c|c|c|c|c|}
\hline $\begin{array}{c}\text { Reaction } \\
\text { Time }(\mathrm{h})\end{array}$ & $\begin{array}{c}\text { Soluble } \\
\text { NaTPB } \\
(\mathrm{mmo} / \mathrm{L})\end{array}$ & $\begin{array}{c}3 \mathrm{~PB} \\
(\mathrm{mmol} / \mathrm{L})\end{array}$ & $\begin{array}{c}2 \mathrm{~PB} \\
(\mathrm{mmol} / \mathrm{L})\end{array}$ & $\begin{array}{c}1 \mathrm{~PB} \\
(\mathrm{mmol} / \mathrm{L})\end{array}$ & $\begin{array}{c}\text { Phenol } \\
(\mathrm{mmol} / \mathrm{L})\end{array}$ & $\begin{array}{c}\text { Soluble } \\
\text { Boron } \\
(\mathrm{mmol} / \mathrm{L})\end{array}$ & $\begin{array}{c}\text { Soluble } \\
\text { Organic } \\
\text { Boron } \\
(\mathrm{mmo} / \mathrm{L})\end{array}$ \\
\hline 15 & 21.5 & 1.02 & 0.57 & $<0.08$ & 1.49 & 21.9 & 23.1 \\
\hline 37 & 21.7 & 1.42 & 0.64 & $<0.08$ & 1.53 & 22.6 & 23.8 \\
\hline 107 & 19.1 & 9.73 & 1.71 & 0.70 & 2.00 & 31.1 & 31.3 \\
\hline 177 & 18.6 & 12.22 & 2.60 & 0.62 & 1.93 & 35.3 & 34.1 \\
\hline 268 & 18.2 & 13.61 & 3.43 & 0.73 & 1.83 & 40.6 & 35.9 \\
\hline 434 & 17.2 & 15.37 & 3.88 & 1.07 & 2.52 & 43.2 & 37.5 \\
\hline 600 & 15.3 & 15.91 & 5.21 & 1.66 & 2.42 & 45.9 & 38.1 \\
\hline 767 & 13.5 & 16.04 & 6.29 & 2.32 & 2.89 & 51.0 & 38.1 \\
\hline
\end{tabular}

\subsection{Data from Test 103}

\begin{tabular}{|c|c|c|c|c|c|c|c|}
\hline $\begin{array}{c}\text { Reaction } \\
\text { Time (h) }\end{array}$ & $\begin{array}{c}\text { Soluble } \\
\text { NaTPB } \\
(\mathrm{mmo} / \mathrm{L})\end{array}$ & $\begin{array}{c}3 \mathrm{~PB} \\
(\mathrm{mmo} / \mathrm{L})\end{array}$ & $\begin{array}{c}2 \mathrm{~PB} \\
(\mathrm{mmol} / \mathrm{L})\end{array}$ & $\begin{array}{c}1 \mathrm{~PB} \\
(\mathrm{mmol} / \mathrm{L})\end{array}$ & $\begin{array}{c}\text { Phenol } \\
(\mathrm{mmo} / \mathrm{L})\end{array}$ & $\begin{array}{c}\text { Soluble } \\
\text { Boron } \\
(\mathrm{mmol} / \mathrm{L})\end{array}$ & $\begin{array}{c}\text { Soluble } \\
\text { Organic } \\
\text { Boron } \\
(\mathrm{mmo} / \mathrm{L})\end{array}$ \\
\hline 15 & 23.7 & 1.41 & $<0.05$ & 0.92 & 1.51 & 22.2 & 26.1 \\
\hline 37 & 22.0 & 1.01 & 0.18 & 0.92 & 1.49 & 22.4 & 24.1 \\
\hline 107 & 18.9 & 7.50 & 2.34 & 1.35 & 1.64 & 29.5 & 30.1 \\
\hline 177 & 19.2 & 9.19 & 3.06 & 1.52 & 1.89 & 34.4 & 33.0 \\
\hline 268 & 18.8 & 10.4 & 3.24 & 1.59 & 1.77 & 39.4 & 34.0 \\
\hline 434 & 17.0 & 11.2 & 6.03 & 2.03 & 2.48 & 44.6 & 36.3 \\
\hline 600 & 13.6 & 11.8 & 8.73 & 4.17 & 2.73 & 47.0 & 38.3 \\
\hline 767 & 10.3 & 11.0 & 7.14 & 6.94 & 3.76 & 52.0 & 35.4 \\
\hline
\end{tabular}




\subsection{Data from Test 104}

\begin{tabular}{|c|c|c|c|c|c|c|c|}
\hline $\begin{array}{c}\text { Reaction } \\
\text { Time }(\mathrm{h})\end{array}$ & $\begin{array}{c}\text { Soluble } \\
\text { NaTPB } \\
(\mathrm{mmol} / \mathrm{L})\end{array}$ & $\begin{array}{c}3 \mathrm{~PB} \\
(\mathrm{mmol} / \mathrm{L})\end{array}$ & $\begin{array}{c}2 \mathrm{~PB} \\
(\mathrm{mmo} / \mathrm{L})\end{array}$ & $\begin{array}{c}\text { 1PB } \\
(\mathrm{mmo} / \mathrm{L})\end{array}$ & $\begin{array}{c}\text { Phenol } \\
(\mathrm{mmol} / \mathrm{L})\end{array}$ & $\begin{array}{c}\text { Soluble } \\
\text { Boron } \\
(\mathrm{mmol} / \mathrm{L})\end{array}$ & $\begin{array}{c}\text { Soluble } \\
\text { Organic } \\
\text { Boron } \\
(\mathrm{mmol} / \mathrm{L})\end{array}$ \\
\hline 15 & 23.4 & $<0.41$ & 0.51 & 0.91 & 1.35 & 22.0 & 25.2 \\
\hline 37 & 22.7 & 0.24 & 0.52 & 0.93 & 1.41 & 22.3 & 24.4 \\
\hline 107 & 19.1 & 6.56 & 0.99 & 1.04 & 1.63 & 28.6 & 27.7 \\
\hline 177 & 18.9 & 10.4 & 1.97 & 1.33 & 1.75 & 33.9 & 32.6 \\
\hline 268 & 18.4 & 12.7 & 2.69 & 1.46 & 1.69 & 39.9 & 35.3 \\
\hline 434 & 17.0 & 14.6 & 3.65 & 1.55 & 2.26 & 43.1 & 36.7 \\
\hline 600 & 14.9 & 15.6 & 4.27 & 2.63 & 2.07 & 47.2 & 37.4 \\
\hline 767 & 13.2 & 16.2 & 4.98 & 2.25 & 2.79 & 50.8 & 36.6 \\
\hline
\end{tabular}

\subsection{Data from Test 105}

\begin{tabular}{|c|c|c|c|c|c|c|c|}
\hline $\begin{array}{c}\text { Reaction } \\
\text { Time (h) }\end{array}$ & $\begin{array}{c}\text { Soluble } \\
\text { NaTPB } \\
(\mathrm{mmo} / \mathrm{L})\end{array}$ & $\begin{array}{c}3 \mathrm{~PB} \\
(\mathrm{mmo} / \mathrm{L})\end{array}$ & $\begin{array}{c}2 \mathrm{~PB} \\
(\mathrm{mmol} / \mathrm{L})\end{array}$ & $\begin{array}{c}1 \mathrm{~PB} \\
(\mathrm{mmo} / \mathrm{L})\end{array}$ & $\begin{array}{c}\text { Phenol } \\
(\mathrm{mmo} / \mathrm{L})\end{array}$ & $\begin{array}{c}\text { Soluble } \\
\text { Boron } \\
(\mathrm{mmol} / \mathrm{L})\end{array}$ & $\begin{array}{c}\text { Soluble } \\
\text { Organic } \\
\text { Boron } \\
(\mathrm{mmo} / \mathrm{L})\end{array}$ \\
\hline 15 & 23.1 & $<0.41$ & $<0.55$ & 0.84 & 3.11 & 20.4 & 24.9 \\
\hline 37 & 22.2 & 0.07 & 0.08 & 0.91 & 1.37 & 21.8 & 23.2 \\
\hline 107 & 19.5 & 6.08 & 1.61 & 1.12 & 1.63 & 27.4 & 28.3 \\
\hline 177 & 18.9 & 8.62 & 2.97 & 1.54 & 1.72 & 34.2 & 32.1 \\
\hline 268 & 18.5 & 10.4 & 3.46 & 1.67 & 1.69 & 38.5 & 34.0 \\
\hline 434 & 17.3 & 12.2 & 4.18 & 2.08 & 2.26 & 43.7 & 35.7 \\
\hline 600 & 14.1 & 12.4 & 6.90 & 2.80 & 2.34 & 49.2 & 36.2 \\
\hline 767 & 10.9 & 11.5 & 8.58 & 5.29 & 3.06 & 50.8 & 36.2 \\
\hline
\end{tabular}

\subsection{Data from Test 106}

\begin{tabular}{|c|c|c|c|c|c|c|c|}
\hline $\begin{array}{c}\text { Reaction } \\
\text { Time (h) }\end{array}$ & $\begin{array}{c}\text { Soluble } \\
\text { NaTPB } \\
(\mathrm{mmo} / \mathrm{L})\end{array}$ & $\begin{array}{c}3 \mathrm{~PB} \\
(\mathrm{mmo} / \mathrm{L})\end{array}$ & $\begin{array}{c}2 \mathrm{~PB} \\
(\mathrm{mmol} / \mathrm{L})\end{array}$ & $\begin{array}{c}1 \mathrm{~PB} \\
(\mathrm{mmo} / \mathrm{L})\end{array}$ & $\begin{array}{c}\text { Phenol } \\
(\mathrm{mmo} / \mathrm{L})\end{array}$ & $\begin{array}{c}\text { Soluble } \\
\text { Boron } \\
(\mathrm{mmol} / \mathrm{L})\end{array}$ & $\begin{array}{c}\text { Soluble } \\
\text { Organic } \\
\text { Boron } \\
(\mathrm{mmo} / \mathrm{L})\end{array}$ \\
\hline 15 & 21.6 & $<0.41$ & $<0.55$ & $<0.08$ & 1.36 & 20.7 & 22.6 \\
\hline 37 & 21.9 & 0.29 & 0.54 & $<0.08$ & 1.41 & 21.7 & 23.1 \\
\hline 107 & 19.7 & 8.80 & 1.41 & 0.31 & 1.80 & 29.4 & 30.4 \\
\hline 177 & 19.1 & 10.9 & 2.19 & 0.45 & 1.70 & 33.8 & 32.7 \\
\hline 268 & 18.9 & 12.2 & 2.86 & 0.58 & 1.65 & 38.0 & 34.6 \\
\hline 434 & 17.5 & 13.2 & 3.98 & 1.05 & 2.24 & 43.5 & 35.7 \\
\hline 600 & 15.7 & 13.6 & 5.63 & 2.03 & 2.18 & 45.7 & 36.9 \\
\hline 767 & 13.6 & 14.1 & 6.64 & 1.96 & 2.64 & 50.6 & 36.2 \\
\hline
\end{tabular}




\subsection{Data from Test 107}

\begin{tabular}{|c|c|c|c|c|c|c|c|}
\hline $\begin{array}{c}\text { Reaction } \\
\text { Time (h) }\end{array}$ & $\begin{array}{c}\text { Soluble } \\
\text { NaTPB } \\
(\mathrm{mmo} / \mathrm{L})\end{array}$ & $\begin{array}{c}3 \mathrm{~PB} \\
(\mathrm{mmo} / \mathrm{L})\end{array}$ & $\begin{array}{c}2 \mathrm{~PB} \\
(\mathrm{mmol} / \mathrm{L})\end{array}$ & $\begin{array}{c}1 \mathrm{~PB} \\
(\mathrm{mmol} / \mathrm{L})\end{array}$ & $\begin{array}{c}\text { Phenol } \\
(\mathrm{mmol} / \mathrm{L})\end{array}$ & $\begin{array}{c}\text { Soluble } \\
\text { Boron } \\
(\mathrm{mmol} / \mathrm{L})\end{array}$ & $\begin{array}{c}\text { Soluble } \\
\text { Organic } \\
\text { Boron } \\
(\mathrm{mmol} / \mathrm{L})\end{array}$ \\
\hline 15 & 21.0 & 1.04 & $<0.55$ & $<0.08$ & 1.52 & 21.5 & 22.7 \\
\hline 37 & 23.1 & 1.05 & 0.19 & $<0.08$ & 1.53 & 22.1 & 24.4 \\
\hline 107 & 22.2 & 1.35 & 0.26 & $<0.08$ & 1.52 & 23.7 & 23.9 \\
\hline 197 & 19.3 & 9.18 & 3.05 & 0.84 & 1.84 & 33.7 & 32.4 \\
\hline 268 & 18.3 & 10.9 & 3.79 & 1.01 & 1.86 & 38.6 & 34.0 \\
\hline 434 & 17.2 & 12.8 & 4.98 & 1.48 & 2.42 & 44.2 & 36.5 \\
\hline 600 & 15.3 & 13.9 & 5.90 & 2.58 & 2.36 & 45.5 & 37.8 \\
\hline 767 & 12.6 & 13.9 & 6.81 & 2.34 & 2.73 & 50.0 & 35.6 \\
\hline
\end{tabular}

\subsection{Data from Test 108}

\begin{tabular}{|c|c|c|c|c|c|c|c|}
\hline $\begin{array}{c}\text { Reaction } \\
\text { Time }(\mathrm{h})\end{array}$ & $\begin{array}{c}\text { Soluble } \\
\text { NaTPB } \\
(\mathrm{mmol} / \mathrm{L})\end{array}$ & $\begin{array}{c}3 \mathrm{~PB} \\
(\mathrm{mmol} / \mathrm{L})\end{array}$ & $\begin{array}{c}2 \mathrm{~PB} \\
(\mathrm{mmol} / \mathrm{L})\end{array}$ & $\begin{array}{c}1 \mathrm{~PB} \\
(\mathrm{mmo} / \mathrm{L})\end{array}$ & $\begin{array}{c}\text { Phenol } \\
(\mathrm{mmol} / \mathrm{L})\end{array}$ & $\begin{array}{c}\text { Soluble } \\
\text { Boron } \\
(\mathrm{mmol} / \mathrm{L})\end{array}$ & $\begin{array}{c}\text { Soluble } \\
\text { Organic } \\
\text { Boron } \\
(\mathrm{mmo} / \mathrm{L})\end{array}$ \\
\hline 15 & 22.3 & $<0.41$ & $<0.55$ & $<0.08$ & 1.23 & 22.0 & 23.4 \\
\hline 37 & 23.7 & 0.41 & 0.12 & $<0.08$ & 1.36 & 12.3 & 24.3 \\
\hline 107 & 20.2 & 4.09 & 0.87 & 0.20 & 1.62 & 25.0 & 25.3 \\
\hline 197 & 19.1 & 8.96 & 2.72 & 0.65 & 1.63 & 33.2 & 31.4 \\
\hline 268 & 19.2 & 10.5 & 3.13 & 0.75 & 1.65 & 38.2 & 33.6 \\
\hline 434 & 17.7 & 11.7 & 4.02 & 1.01 & 2.07 & 42.4 & 34.4 \\
\hline 600 & 16.3 & 12.9 & 4.83 & 1.75 & 1.94 & 44.5 & 35.7 \\
\hline 767 & 14.2 & 13.5 & 5.81 & 1.48 & 2.26 & 47.8 & 35.0 \\
\hline
\end{tabular}

\subsection{Data from Test 109}

\begin{tabular}{|c|c|c|c|c|c|c|c|}
\hline $\begin{array}{c}\text { Reaction } \\
\text { Time }(\mathrm{h})\end{array}$ & $\begin{array}{c}\text { Soluble } \\
\text { NaTPB } \\
(\mathrm{mmo} / \mathrm{L})\end{array}$ & $\begin{array}{c}3 \mathrm{~PB} \\
(\mathrm{mmo} / \mathrm{L})\end{array}$ & $\begin{array}{c}2 \mathrm{~PB} \\
(\mathrm{mmo} / \mathrm{L})\end{array}$ & $\begin{array}{c}1 \mathrm{~PB} \\
(\mathrm{mmo} / \mathrm{L})\end{array}$ & $\begin{array}{c}\text { Phenol } \\
(\mathrm{mmo} / \mathrm{L})\end{array}$ & $\begin{array}{c}\text { Soluble } \\
\text { Boron } \\
(\mathrm{mmo} / \mathrm{L})\end{array}$ & $\begin{array}{c}\text { Soluble } \\
\text { Organic } \\
\text { Boron } \\
(\mathrm{mmol} / \mathrm{L})\end{array}$ \\
\hline 15 & 23.1 & 9.18 & 6.84 & 8.41 & 2.55 & 46.1 & 47.5 \\
\hline 37 & 22.7 & 9.14 & 6.59 & 9.05 & 2.56 & 45.3 & 47.5 \\
\hline 107 & 22.6 & 9.46 & 6.40 & 10.1 & 3.58 & 51.2 & 48.5 \\
\hline 197 & 22.9 & 9.76 & 5.24 & 11.0 & 3.04 & 53.8 & 48.9 \\
\hline 268 & 24.1 & 10.1 & 4.77 & 11.6 & 3.18 & 57.7 & 50.5 \\
\hline 434 & 23.2 & 9.79 & 2.30 & 10.9 & 3.68 & 60.3 & 46.2 \\
\hline 600 & 23.0 & 9.72 & 0.82 & 9.81 & 3.90 & 60.5 & 43.4 \\
\hline 767 & 22.2 & 9.28 & 0.62 & 7.47 & 4.13 & 65.1 & 39.5 \\
\hline 931 & 23.9 & 9.82 & 0.59 & 10.3 & 4.34 & 75.1 & 44.6 \\
\hline 1097 & 27.5 & 9.75 & 0.76 & 6.64 & 5.65 & 72.4 & 44.7 \\
\hline 1262 & 23.7 & 9.45 & 0.63 & 6.50 & 5.08 & 84.3 & 40.3 \\
\hline 1423 & 23.3 & 9.45 & 0.74 & 5.49 & 5.66 & 98.4 & 39.0 \\
\hline 1636 & 22.7 & 9.59 & 0.70 & 5.08 & 5.70 & 114 & 38.0 \\
\hline
\end{tabular}




\subsection{Data from Test 110}

\begin{tabular}{|c|c|c|c|c|c|c|c|}
\hline $\begin{array}{c}\text { Reaction } \\
\text { Time }(\mathrm{h})\end{array}$ & $\begin{array}{c}\text { Soluble } \\
\text { NaTPB } \\
(\mathrm{mmol} / \mathrm{L})\end{array}$ & $\begin{array}{c}3 \mathrm{~PB} \\
(\mathrm{mmo} / \mathrm{L})\end{array}$ & $\begin{array}{c}2 \mathrm{~PB} \\
(\mathrm{mmo} / \mathrm{L})\end{array}$ & $\begin{array}{c}1 \mathrm{~PB} \\
(\mathrm{mmol} / \mathrm{L})\end{array}$ & $\begin{array}{c}\text { Phenol } \\
(\mathrm{mmo} / \mathrm{L})\end{array}$ & $\begin{array}{c}\text { Soluble } \\
\text { Boron } \\
(\mathrm{mmol} / \mathrm{L})\end{array}$ & $\begin{array}{c}\text { Soluble } \\
\text { Organic } \\
\text { Boron } \\
(\mathrm{mmo} / \mathrm{L})\end{array}$ \\
\hline 15 & 23.3 & 8.54 & 7.27 & 9.28 & 2.71 & 46.0 & 48.4 \\
\hline 37 & 23.8 & 9.53 & 6.81 & 8.73 & 2.55 & 46.2 & 48.9 \\
\hline 107 & 22.7 & 9.44 & 7.19 & 9.72 & 3.61 & 50.6 & 49.1 \\
\hline 197 & 23.6 & 9.89 & 7.23 & 10.2 & 2.90 & 53.4 & 51.0 \\
\hline 268 & 23.5 & 9.88 & 6.74 & 10.4 & 2.96 & 57.3 & 50.5 \\
\hline 434 & 23.7 & 9.96 & 6.65 & 10.5 & 3.36 & 59.9 & 50.8 \\
\hline 600 & 23.2 & 9.82 & 5.49 & 10.9 & 3.30 & 60.7 & 49.4 \\
\hline 767 & 23.1 & 9.60 & 4.61 & 11.3 & 3.93 & 64.8 & 48.6 \\
\hline 931 & 24.2 & 10.1 & 4.31 & 14.6 & 3.88 & 74.4 & 53.2 \\
\hline 1097 & 24.3 & 9.80 & 3.86 & 10.4 & 5.61 & 77.3 & 48.4 \\
\hline 1262 & 24.5 & 9.91 & 3.55 & 9.85 & 4.92 & 86.9 & 47.8 \\
\hline 1423 & 23.4 & 9.64 & 3.23 & 9.93 & 5.76 & 98.3 & 46.2 \\
\hline 1636 & 21.9 & 9.59 & 2.37 & 9.19 & 6.38 & 110 & 43.0 \\
\hline
\end{tabular}

\subsection{Data from Test 111}

\begin{tabular}{|c|c|c|c|c|c|c|c|}
\hline $\begin{array}{c}\text { Reaction } \\
\text { Time }(\mathrm{h})\end{array}$ & $\begin{array}{c}\text { Soluble } \\
\text { NaTPB } \\
(\mathrm{mmo} / \mathrm{L})\end{array}$ & $\begin{array}{c}3 \mathrm{~PB} \\
(\mathrm{mmo} / \mathrm{L})\end{array}$ & $\begin{array}{c}2 \mathrm{~PB} \\
(\mathrm{mmol} / \mathrm{L})\end{array}$ & $\begin{array}{c}1 \mathrm{~PB} \\
(\mathrm{mmol} / \mathrm{L})\end{array}$ & $\begin{array}{c}\text { Phenol } \\
(\mathrm{mmo} / \mathrm{L})\end{array}$ & $\begin{array}{c}\text { Soluble } \\
\text { Boron } \\
(\mathrm{mmol} / \mathrm{L})\end{array}$ & $\begin{array}{c}\text { Soluble } \\
\text { Organic } \\
\text { Boron } \\
(\mathrm{mmo} / \mathrm{L})\end{array}$ \\
\hline 15 & 22.9 & 8.40 & 19.2 & 25.3 & 0.11 & 80.2 & 75.8 \\
\hline 37 & 25.9 & 9.35 & 21.0 & 29.2 & 2.60 & 80.2 & 85.4 \\
\hline 107 & 24.2 & 9.26 & 19.7 & 29.7 & 3.28 & 85.1 & 82.9 \\
\hline 197 & 25.1 & 9.73 & 13.8 & 34.8 & 3.54 & 89.6 & 83.5 \\
\hline 268 & 25.6 & 9.87 & 7.15 & 35.9 & 3.97 & 92.5 & 78.5 \\
\hline 434 & 24.6 & 9.75 & 1.71 & 27.7 & 4.73 & 97.3 & 63.8 \\
\hline 600 & 24.4 & 9.85 & 0.91 & 21.5 & 5.21 & 97.1 & 56.6 \\
\hline 767 & 23.0 & 9.60 & 4.54 & 10.8 & 3.88 & 64.9 & 48.0 \\
\hline 931 & 24.1 & 9.79 & 0.31 & 13.9 & 5.98 & 110 & 48.1 \\
\hline 1097 & 24.1 & 9.36 & 0.36 & 11.8 & 7.52 & 109 & 45.5 \\
\hline 1262 & 24.6 & 9.55 & 0.41 & 11.1 & 6.47 & 121 & 45.6 \\
\hline 1423 & 24.0 & 9.33 & 0.51 & 9.70 & 6.81 & 128 & 43.5 \\
\hline 1636 & 25.1 & 10.2 & 0.64 & 8.96 & 6.92 & 140 & 44.9 \\
\hline
\end{tabular}


10.0 Appendix B - Excess Sodium Tetraphenylborate Studies Test Data

10.1 Data from Test 201

\begin{tabular}{|c|c|c|c|c|c|c|c|}
\hline $\begin{array}{c}\text { Reaction } \\
\text { Time }(\mathrm{h})\end{array}$ & $\begin{array}{c}\text { Soluble } \\
\text { NaTPB } \\
(\mathrm{mmol} / \mathrm{L})\end{array}$ & $\begin{array}{c}3 \mathrm{~PB} \\
(\mathrm{mmol} / \mathrm{L})\end{array}$ & $\begin{array}{c}2 \mathrm{~PB} \\
(\mathrm{mmol} / \mathrm{L})\end{array}$ & $\begin{array}{c}1 \mathrm{~PB} \\
(\mathrm{mmol} / \mathrm{L})\end{array}$ & $\begin{array}{c}\text { Phenol } \\
(\mathrm{mmol} / \mathrm{L})\end{array}$ & $\begin{array}{c}\text { Soluble } \\
\text { Boron } \\
(\mathrm{mmol} / \mathrm{L})\end{array}$ & $\begin{array}{c}\text { Soluble } \\
\text { Organic } \\
\text { Boron } \\
(\mathrm{mmol} / \mathrm{L})\end{array}$ \\
\hline 17 & 1.10 & 4.25 & 2.85 & 2.57 & 2.00 & 11.5 & 10.8 \\
\hline 93 & 1.16 & 4.31 & 2.62 & 2.79 & 2.60 & 11.3 & 10.9 \\
\hline 186 & 1.08 & 4.24 & 2.42 & 2.73 & 2.52 & 11.5 & 10.5 \\
\hline 253 & 1.17 & 4.30 & 2.18 & 3.08 & 2.90 & 11.2 & 10.7 \\
\hline 421 & 1.03 & 4.08 & 1.57 & 2.94 & 3.42 & 12.4 & 9.6 \\
\hline 587 & 1.22 & 4.39 & 1.24 & 3.49 & 3.97 & 12.0 & 10.3 \\
\hline 749 & 0.91 & 3.83 & 0.88 & 2.66 & 4.02 & 11.7 & 8.3 \\
\hline 914 & 1.03 & 3.90 & 0.70 & 4.51 & 4.41 & 14.2 & 10.1 \\
\hline 1244 & 1.19 & 4.22 & 0.52 & 2.35 & 5.07 & 9.3 & 8.3 \\
\hline 1621 & 1.11 & 3.99 & 0.49 & 1.94 & 5.40 & 11.7 & 7.5 \\
\hline 1929 & 1.01 & 3.70 & 0.31 & 1.74 & 5.77 & 13.8 & 6.8 \\
\hline 2288 & 1.05 & 3.80 & 0.27 & 1.55 & 6.10 & 12.7 & 6.7 \\
\hline 2598 & 1.25 & 4.68 & 0.21 & 1.44 & 6.59 & 13.7 & 7.6 \\
\hline 3268 & 1.12 & 4.06 & 0.21 & 1.20 & 6.84 & 13.8 & 6.6 \\
\hline 3990 & 1.21 & 3.99 & 0.21 & 0.80 & 6.96 & 19.4 & 6.2 \\
\hline
\end{tabular}

10.2 Data from Test 202

\begin{tabular}{|c|c|c|c|c|c|c|c|}
\hline $\begin{array}{c}\text { Reaction } \\
\text { Time }(\mathrm{h})\end{array}$ & $\begin{array}{c}\text { Soluble } \\
\text { NaTPB } \\
(\mathrm{mmol} / \mathrm{L})\end{array}$ & $\begin{array}{c}3 \mathrm{~PB} \\
(\mathrm{mmol} / \mathrm{L})\end{array}$ & $\begin{array}{c}2 \mathrm{~PB} \\
(\mathrm{mmol} / \mathrm{L})\end{array}$ & $\begin{array}{c}1 \mathrm{~PB} \\
(\mathrm{mmol} / \mathrm{L})\end{array}$ & $\begin{array}{c}\text { Phenol } \\
(\mathrm{mmol} / \mathrm{L})\end{array}$ & $\begin{array}{c}\text { Soluble } \\
\text { Boron } \\
(\mathrm{mmol} / \mathrm{L})\end{array}$ & $\begin{array}{c}\text { Soluble } \\
\text { Organic } \\
\text { Boron } \\
(\mathrm{mmol} / \mathrm{L})\end{array}$ \\
\hline 17 & 1.08 & 4.13 & 2.72 & 2.52 & 1.92 & 11.2 & 10.4 \\
\hline 93 & 1.26 & 4.41 & 2.71 & 2.73 & 2.52 & 11.4 & 11.1 \\
\hline 186 & 1.20 & 4.32 & 2.51 & 2.69 & 2.44 & 11.6 & 10.7 \\
\hline 253 & 1.21 & 4.27 & 2.46 & 2.87 & 2.71 & 12.0 & 10.8 \\
\hline 421 & 1.09 & 4.11 & 2.03 & 2.75 & 2.99 & 12.0 & 10.0 \\
\hline 587 & 1.20 & 4.21 & 1.65 & 3.26 & 3.30 & 12.3 & 10.3 \\
\hline 749 & 0.98 & 3.92 & 1.46 & 2.73 & 3.53 & 11.6 & 9.1 \\
\hline 914 & 1.11 & 4.06 & 1.30 & 4.66 & 3.90 & 13.6 & 11.1 \\
\hline 1244 & 1.09 & 3.93 & 0.81 & 2.56 & 4.49 & 10.8 & 8.4 \\
\hline 1621 & 1.12 & 4.06 & 0.66 & 2.31 & 5.30 & 11.6 & 8.2 \\
\hline 1929 & 1.01 & 3.81 & 0.43 & 2.24 & 5.53 & 13.6 & 7.5 \\
\hline 2288 & 1.07 & 3.85 & 0.31 & 1.79 & 5.87 & 12.9 & 7.0 \\
\hline 2598 & 1.05 & 4.16 & 0.25 & 1.62 & 6.97 & 13.8 & 7.1 \\
\hline 3268 & 1.19 & 4.27 & 0.21 & 1.30 & 6.64 & 14.1 & 7.0 \\
\hline 3990 & 1.21 & 4.04 & 0.21 & 0.94 & 6.91 & 19.33 & 6.4 \\
\hline
\end{tabular}




\subsection{Data from Test 203}

\begin{tabular}{|c|c|c|c|c|c|c|c|}
\hline $\begin{array}{c}\text { Reaction } \\
\text { Time (h) }\end{array}$ & $\begin{array}{c}\text { Soluble } \\
\text { NaTPB } \\
(\mathrm{mmol} / \mathrm{L})\end{array}$ & $\begin{array}{c}3 \mathrm{~PB} \\
(\mathrm{mmol} / \mathrm{L})\end{array}$ & $\begin{array}{c}2 \mathrm{~PB} \\
(\mathrm{mmo} / \mathrm{L})\end{array}$ & $\begin{array}{c}\text { 1PB } \\
(\mathrm{mmol} / \mathrm{L})\end{array}$ & $\begin{array}{c}\text { Phenol } \\
(\mathrm{mmol} / \mathrm{L})\end{array}$ & $\begin{array}{c}\text { Soluble } \\
\text { Boron } \\
(\mathrm{mmol} / \mathrm{L})\end{array}$ & $\begin{array}{c}\text { Soluble } \\
\text { Organic } \\
\text { Boron } \\
(\mathrm{mmol} / \mathrm{L})\end{array}$ \\
\hline 17 & 1.16 & 4.40 & 2.59 & 2.50 & 2.41 & 12.5 & 10.7 \\
\hline 90 & 1.12 & 4.20 & 1.01 & 2.82 & 3.67 & 12.4 & 9.2 \\
\hline 157 & 1.24 & 4.13 & 0.52 & 2.35 & 4.34 & 12.9 & 8.2 \\
\hline 249 & 1.26 & 4.17 & $<0.05$ & 1.80 & 4.90 & 14.3 & 7.3 \\
\hline 413 & 0.99 & 3.91 & 0.29 & 1.11 & 5.61 & 16.4 & 6.3 \\
\hline 578 & 1.12 & 3.93 & 0.26 & 0.78 & 6.16 & 17.3 & 6.1 \\
\hline 742 & 1.01 & 3.70 & 0.21 & 0.49 & 6.61 & 18.6 & 5.4 \\
\hline 906 & 1.07 & 3.56 & 0.17 & 0.40 & 7.20 & 20.7 & 5.2 \\
\hline 1234 & 1.05 & 3.08 & 0.24 & 0.38 & 7.91 & 24.7 & 4.7 \\
\hline 1397 & 1.08 & 2.97 & 0.13 & 0.26 & 8.39 & 26.4 & 4.4 \\
\hline 1611 & 1.10 & 2.94 & 0.15 & 0.22 & 9.07 & 25.5 & 4.4 \\
\hline 1919 & 1.14 & 2.71 & 0.13 & 0.19 & 9.32 & 30.0 & 4.2 \\
\hline 2277 & 1.22 & 2.54 & 0.14 & 0.31 & 10.99 & 34.7 & 4.2 \\
\hline 2586 & 1.15 & 2.34 & 0.13 & 0.12 & 10.71 & 42.7 & 3.7 \\
\hline 3255 & 1.06 & 1.21 & 0.10 & 0.15 & 12.19 & 55.7 & 2.5 \\
\hline 3977 & 1.05 & 1.69 & .09 & 0.08 & 12.62 & 77.4 & 2.9 \\
\hline
\end{tabular}

\subsection{Data from Test 204}

\begin{tabular}{|c|c|c|c|c|c|c|c|}
\hline $\begin{array}{c}\text { Reaction } \\
\text { Time }(\mathrm{h})\end{array}$ & $\begin{array}{c}\text { Soluble } \\
\text { NaTPB } \\
(\mathrm{mmol} / \mathrm{L})\end{array}$ & $\begin{array}{c}3 \mathrm{~PB} \\
(\mathrm{mmo} / \mathrm{L})\end{array}$ & $\begin{array}{c}2 \mathrm{~PB} \\
(\mathrm{mmol} / \mathrm{L})\end{array}$ & $\begin{array}{c}1 \mathrm{~PB} \\
(\mathrm{mmo} / \mathrm{L})\end{array}$ & $\begin{array}{c}\text { Phenol } \\
(\mathrm{mmol} / \mathrm{L})\end{array}$ & $\begin{array}{c}\text { Soluble } \\
\text { Boron } \\
(\mathrm{mmol} / \mathrm{L})\end{array}$ & $\begin{array}{c}\text { Soluble } \\
\text { Organic } \\
\text { Boron } \\
(\mathrm{mmol} / \mathrm{L})\end{array}$ \\
\hline 17 & 1.16 & 4.20 & 2.48 & 2.49 & 2.39 & 12.5 & 10.3 \\
\hline 90 & 1.15 & 4.08 & 1.26 & 2.73 & 3.50 & 12.6 & 9.2 \\
\hline 157 & 1.29 & 4.35 & 0.63 & 2.52 & 4.46 & 12.8 & 8.8 \\
\hline 249 & 1.22 & 4.53 & $<0.05$ & 1.92 & 5.07 & 14.2 & 7.7 \\
\hline 413 & 1.07 & 5.15 & 0.37 & 1.18 & 5.82 & 17.0 & 7.8 \\
\hline 578 & 1.18 & 6.08 & 0.45 & 1.20 & 6.40 & 19.8 & 8.9 \\
\hline 742 & 1.01 & 5.93 & 0.38 & 0.72 & 6.87 & 21.3 & 8.0 \\
\hline 906 & 1.10 & 6.28 & 0.41 & 0.71 & 8.50 & 23.9 & 8.5 \\
\hline 1070 & 1.11 & 6.14 & 0.36 & 0.57 & 9.41 & 24.7 & 8.2 \\
\hline 1234 & 1.05 & 5.58 & 0.29 & 0.68 & 8.76 & 27.9 & 7.6 \\
\hline 1397 & 1.06 & 5.30 & 0.27 & 0.52 & 9.17 & 29.7 & 7.2 \\
\hline 1611 & 1.09 & 5.53 & 0.31 & 0.50 & 10.63 & 29.3 & 7.4 \\
\hline 1919 & 1.13 & 5.18 & 0.29 & 0.42 & 11.05 & 35.5 & 7.0 \\
\hline 2277 & 1.20 & 4.64 & 0.24 & 0.30 & 12.58 & 42.6 & 6.4 \\
\hline 2586 & 1.27 & 5.08 & 0.20 & 0.02 & 13.37 & 54.3 & 6.6 \\
\hline 3255 & 1.10 & 4.38 & 0.16 & 0.21 & 15.31 & 63.3 & 5.9 \\
\hline 3977 & 0.84 & 3.42 & 0.15 & 0.19 & 16.41 & 88.6 & 4.6 \\
\hline
\end{tabular}




\subsection{Data from Test 205}

\begin{tabular}{|c|c|c|c|c|c|c|c|}
\hline $\begin{array}{c}\text { Reaction } \\
\text { Time }(\mathrm{h})\end{array}$ & $\begin{array}{c}\text { Soluble } \\
\text { NaTPB } \\
(\mathrm{mmol} / \mathrm{L})\end{array}$ & $\begin{array}{c}3 \mathrm{~PB} \\
(\mathrm{mmo} / \mathrm{L})\end{array}$ & $\begin{array}{c}2 \mathrm{~PB} \\
(\mathrm{mmol} / \mathrm{L})\end{array}$ & $\begin{array}{c}1 \mathrm{~PB} \\
(\mathrm{mmol} / \mathrm{L})\end{array}$ & $\begin{array}{c}\text { Phenol } \\
(\mathrm{mmol} / \mathrm{L})\end{array}$ & $\begin{array}{c}\text { Soluble } \\
\text { Boron } \\
(\mathrm{mmo} / \mathrm{L})\end{array}$ & $\begin{array}{c}\text { Soluble } \\
\text { Organic } \\
\text { Boron } \\
(\mathrm{mmol} / \mathrm{L})\end{array}$ \\
\hline 18 & 5.51 & 4.57 & 2.70 & 3.14 & 2.60 & 15.7 & 15.9 \\
\hline 67 & 5.46 & 4.59 & 2.47 & 2.58 & 2.37 & 16.2 & 15.1 \\
\hline 136 & 5.56 & 4.56 & 1.97 & 2.94 & 3.10 & 17.1 & 15.0 \\
\hline 300 & 4.97 & 4.31 & 1.15 & 2.74 & 3.81 & 16.8 & 13.2 \\
\hline 465 & 5.42 & 4.51 & 0.76 & 2.57 & 4.41 & 16.4 & 13.2 \\
\hline 628 & 4.97 & 4.12 & 0.58 & 2.16 & 4.75 & 16.9 & 11.8 \\
\hline 788 & 5.21 & 4.18 & 0.49 & 2.19 & 5.24 & 16.6 & 12.1 \\
\hline 1118 & 5.25 & 4.09 & 0.31 & 1.68 & 5.93 & 12.4 & 11.3 \\
\hline 1497 & 5.17 & 4.18 & 0.23 & 1.17 & 6.61 & 17.4 & 10.7 \\
\hline 1807 & 5.27 & 4.09 & 0.19 & 0.90 & 6.75 & 19.6 & 10.4 \\
\hline 2164 & 5.39 & 3.981 & 0.16 & 0.57 & 7.19 & 19.8 & 10.1 \\
\hline 2472 & 5.30 & 4.37 & 0.18 & 0.50 & 7.76 & 20.8 & 10.4 \\
\hline 3142 & 5.49 & 4.46 & 0.16 & 0.35 & 8.51 & 26.2 & 10.5 \\
\hline 3863 & 5.45 & 4.12 & 0.16 & 0.23 & 8.68 & 23.6 & 10.0 \\
\hline
\end{tabular}

\subsection{Data from Test 206}

\begin{tabular}{|c|c|c|c|c|c|c|c|c|}
\hline $\begin{array}{c}\text { Reaction } \\
\text { Time }(\mathrm{h})\end{array}$ & $\begin{array}{c}\text { Soluble } \\
\text { NaTPB } \\
(\mathrm{mmol} / \mathrm{L})\end{array}$ & $\begin{array}{c}3 \mathrm{~PB} \\
(\mathrm{mmol} / \mathrm{L})\end{array}$ & $\begin{array}{c}2 \mathrm{~PB} \\
(\mathrm{mmol} / \mathrm{L})\end{array}$ & $\begin{array}{c}1 \mathrm{~PB} \\
(\mathrm{mmol} / \mathrm{L})\end{array}$ & $\begin{array}{c}\text { Phenol } \\
(\mathrm{mmol} / \mathrm{L})\end{array}$ & $\begin{array}{c}\text { Soluble } \\
\text { Boron } \\
(\mathrm{mmol} / \mathrm{L})\end{array}$ & $\begin{array}{c}\text { Soluble } \\
\text { Organic } \\
\text { Boron } \\
(\mathrm{mmo} / \mathrm{L})\end{array}$ & $\begin{array}{c}\text { Soluble } \\
\text { Potassium } \\
(\mathrm{mmol} / \mathrm{L})\end{array}$ \\
\hline 17 & 5.11 & 4.23 & 2.60 & 2.48 & 2.05 & 15.2 & 14.4 & \\
\hline 90 & 5.33 & 4.36 & 2.21 & 2.76 & 2.74 & 16.1 & 14.7 & \\
\hline 157 & 5.13 & 5.84 & 2.49 & 3.16 & 2.95 & 18.3 & 16.6 & \\
\hline 249 & 4.50 & 10.75 & 4.46 & 3.44 & 2.86 & 24.9 & 23.2 & \\
\hline 413 & 3.99 & 13.00 & 5.53 & 3.63 & 3.26 & 28.6 & 26.1 & \\
\hline 578 & 3.76 & 15.78 & 6.58 & 5.24 & 3.35 & 30.4 & 31.4 & \\
\hline 742 & 2.79 & 16.10 & 7.21 & 3.88 & 3.57 & 33.3 & 30.0 & \\
\hline 906 & 1.92 & 16.67 & 8.66 & 4.04 & 9.72 & 35.1 & 31.3 & \\
\hline 1070 & 0.98 & 16.42 & 10.23 & 4.86 & 11.87 & 33.8 & 32.5 & \\
\hline 1234 & 0.32 & 14.46 & 11.23 & 6.39 & 4.55 & 36.4 & 32.4 & \\
\hline 1397 & 0.06 & 12.13 & 12.13 & 6.36 & 4.72 & 34.6 & 30.7 & \\
\hline 1611 & $<0.03$ & 10.77 & 13.32 & 8.78 & 6.15 & 33.6 & 32.9 & 0.09 \\
\hline 1919 & $<0.03$ & 9.11 & 7.66 & 10.99 & 7.66 & 34.9 & 27.8 & 0.18 \\
\hline 2277 & $<0.03$ & 8.52 & 4.15 & 10.60 & 10.34 & 37.4 & 23.3 & 0.09 \\
\hline 2586 & $<0.03$ & 8.90 & 2.36 & 9.01 & 12.57 & 39.7 & 20.3 & 0.10 \\
\hline
\end{tabular}




\subsection{Data from Test 207}

\begin{tabular}{|c|c|c|c|c|c|c|c|}
\hline $\begin{array}{c}\text { Reaction } \\
\text { Time }(\mathrm{h})\end{array}$ & $\begin{array}{c}\text { Soluble } \\
\text { NaTPB } \\
(\mathrm{mmol})\end{array}$ & $\begin{array}{c}3 \mathrm{~PB} \\
(\mathrm{mmol} / \mathrm{L})\end{array}$ & $\begin{array}{c}2 \mathrm{~PB} \\
(\mathrm{mmol} / \mathrm{L})\end{array}$ & $\begin{array}{c}1 \mathrm{~PB} \\
(\mathrm{mmol} / \mathrm{L})\end{array}$ & $\begin{array}{c}\text { Phenol } \\
(\mathrm{mmo} / \mathrm{L})\end{array}$ & $\begin{array}{c}\text { Soluble } \\
\text { Boron } \\
(\mathrm{mmol} / \mathrm{L})\end{array}$ & $\begin{array}{c}\text { Soluble } \\
\text { Organic } \\
\text { Boron } \\
(\mathrm{mmo} / \mathrm{L})\end{array}$ \\
\hline 18 & 0.21 & 4.27 & 3.07 & 3.18 & 2.66 & 10.7 & 10.7 \\
\hline 67 & 0.20 & 4.34 & 2.56 & 2.87 & 2.69 & 10.7 & 10.0 \\
\hline 136 & 0.20 & 4.09 & 1.80 & 3.19 & 3.47 & 11.7 & 9.3 \\
\hline 300 & 0.17 & 3.92 & 0.74 & 2.89 & 4.19 & 17.5 & 7.7 \\
\hline 465 & 0.17 & 3.98 & 0.52 & 2.62 & 4.60 & 11.7 & 7.3 \\
\hline 628 & 0.15 & 3.55 & 0.42 & 1.98 & 4.82 & 12.4 & 6.1 \\
\hline 788 & 0.11 & 3.59 & 0.38 & 1.75 & 5.24 & 12.7 & 5.8 \\
\hline 1118 & 0.17 & 3.58 & 0.38 & 1.40 & 6.04 & 13.5 & 5.5 \\
\hline 1497 & 0.13 & 3.85 & 0.46 & 1.12 & 6.45 & 15.3 & 5.6 \\
\hline 1807 & 0.16 & 3.98 & 0.47 & 0.97 & 6.80 & 18.6 & 5.6 \\
\hline 2164 & 0.12 & 3.82 & 0.37 & 0.81 & 7.44 & 19.4 & 5.1 \\
\hline 2472 & 0.22 & 3.91 & 0.30 & 0.75 & 8.94 & 22.1 & 5.2 \\
\hline 3142 & 0.18 & 3.79 & 0.27 & 0.56 & 9.15 & 27.3 & 4.8 \\
\hline 3863 & 0.17 & 2.91 & 0.18 & 0.37 & 9.65 & 25.3 & 3.6 \\
\hline
\end{tabular}

\subsection{Data from Test 208}

\begin{tabular}{|c|c|c|c|c|c|c|c|c|}
\hline $\begin{array}{c}\text { Reaction } \\
\text { Time }(\mathrm{h})\end{array}$ & $\begin{array}{c}\text { Soluble } \\
\text { NaTPB } \\
(\mathrm{mmol} / \mathrm{L})\end{array}$ & $\begin{array}{c}3 \mathrm{~PB} \\
(\mathrm{mmol} / \mathrm{L})\end{array}$ & $\begin{array}{c}2 \mathrm{~PB} \\
(\mathrm{mmol} / \mathrm{L})\end{array}$ & $\begin{array}{c}1 \mathrm{~PB} \\
(\mathrm{mmol} / \mathrm{L})\end{array}$ & $\begin{array}{c}\text { Phenol } \\
(\mathrm{mmol} / \mathrm{L})\end{array}$ & $\begin{array}{c}\text { Soluble } \\
\text { Boron } \\
(\mathrm{mmol} / \mathrm{L})\end{array}$ & $\begin{array}{c}\text { Soluble } \\
\text { Organic } \\
\text { Boron } \\
(\mathrm{mmol} / \mathrm{L})\end{array}$ & $\begin{array}{c}\text { Soluble } \\
\text { Potassium } \\
(\mathrm{mmol} / \mathrm{L})\end{array}$ \\
\hline 17 & 0.16 & 3.95 & 2.65 & 3.03 & 2.48 & 10.8 & 9.8 & \\
\hline 90 & 0.22 & 3.80 & 1.79 & 3.38 & 3.43 & 11.4 & 9.2 & \\
\hline 157 & 0.19 & 3.57 & 1.74 & 3.60 & 3.70 & 12.3 & 9.1 & \\
\hline 249 & 0.31 & 4.32 & 3.50 & 4.28 & 4.11 & 15.5 & 12.4 & \\
\hline 413 & 0.15 & 5.95 & 6.45 & 4.65 & 4.44 & 21.3 & 17.2 & \\
\hline 578 & 0.20 & 7.12 & 8.91 & 5.26 & 3.96 & 25.1 & 21.5 & \\
\hline 742 & 0.14 & 6.91 & 9.90 & 5.61 & 3.95 & 27.2 & 22.6 & \\
\hline 906 & 0.13 & 6.96 & 11.85 & 6.15 & 4.86 & 30.5 & 25.1 & \\
\hline 1070 & 0.12 & 7.21 & 13.50 & 7.35 & 5.68 & 30.7 & 28.2 & \\
\hline 1234 & 0.08 & 6.83 & 13.90 & 8.37 & 4.98 & 35.0 & 29.2 & \\
\hline 1397 & $<0.03$ & 5.83 & 15.14 & 9.34 & 6.62 & 35.8 & 30.3 & 0.00 \\
\hline 1611 & $<0.03$ & 3.67 & 16.93 & 10.77 & 5.45 & 37.3 & 31.4 & 0.09 \\
\hline 1919 & $<0.03$ & 1.05 & 15.43 & 13.97 & 6.70 & 37.0 & 30.5 & 0.26 \\
\hline 2277 & $<0.03$ & 0.04 & 7.73 & 17.17 & 9.06 & 40.8 & 25.0 & 0.24 \\
\hline 2586 & $<0.03$ & 0.04 & 2.34 & 15.11 & 12.20 & 37.341 .4 & 17.5 & 0.32 \\
\hline
\end{tabular}


10.9 Data from Test 209

\begin{tabular}{|c|c|c|c|c|c|c|c|}
\hline $\begin{array}{c}\text { Reaction } \\
\text { Time }(\mathrm{h})\end{array}$ & $\begin{array}{c}\text { Soluble } \\
\text { NaTPB } \\
(\mathrm{mmol} / \mathrm{L})\end{array}$ & $\begin{array}{c}3 \mathrm{~PB} \\
(\mathrm{mmol} / \mathrm{L})\end{array}$ & $\begin{array}{c}2 \mathrm{~PB} \\
(\mathrm{mmol} / \mathrm{L})\end{array}$ & $\begin{array}{c}1 \mathrm{~PB} \\
(\mathrm{mmol} / \mathrm{L})\end{array}$ & $\begin{array}{c}\text { Phenol } \\
(\mathrm{mmol} / \mathrm{L})\end{array}$ & $\begin{array}{c}\text { Soluble } \\
\text { Boron } \\
(\mathrm{mmol} / \mathrm{L})\end{array}$ & $\begin{array}{c}\text { Soluble } \\
\text { Organic } \\
\text { Boron } \\
(\mathrm{mmol} / \mathrm{L})\end{array}$ \\
\hline 17 & 1.06 & 4.14 & 2.76 & 2.56 & 1.97 & 11.4 & 10.5 \\
\hline 93 & 1.19 & 4.36 & 2.66 & 2.60 & 2.32 & 11.1 & 10.8 \\
\hline 186 & 1.10 & 4.28 & 2.49 & 2.71 & 2.48 & 11.5 & 10.6 \\
\hline 253 & 1.16 & 4.27 & 2.23 & 2.81 & 2.70 & 12.0 & 10.5 \\
\hline 421 & 1.06 & 4.09 & 1.92 & 2.80 & 2.96 & 11.9 & 9.9 \\
\hline 587 & 1.15 & 4.23 & 1.59 & 3.12 & 3.44 & 12.3 & 10.1 \\
\hline 749 & 0.96 & 3.95 & 1.25 & 2.62 & 3.62 & 11.6 & 8.8 \\
\hline 914 & 1.02 & 3.92 & 0.96 & 4.12 & 4.13 & 13.3 & 10.0 \\
\hline 1244 & 1.12 & 4.11 & 0.58 & 2.55 & 5.08 & 11.0 & 8.4 \\
\hline 1621 & 1.14 & 4.15 & 0.51 & 2.08 & 7.78 & 11.6 & 7.9 \\
\hline 1929 & 1.02 & 3.85 & 0.32 & 1.92 & 5.83 & 13.4 & 7.1 \\
\hline 2288 & 1.16 & 3.87 & 0.27 & 1.59 & 6.30 & 13.0 & 6.9 \\
\hline 2598 & 1.21 & 4.60 & 0.25 & 1.44 & 7.36 & 13.8 & 7.5 \\
\hline 3268 & 1.09 & 4.08 & 0.21 & 1.20 & 6.78 & 13.9 & 6.6 \\
\hline 3990 & 1.20 & 4.06 & 0.23 & 0.87 & 7.04 & 19.0 & 6.4 \\
\hline
\end{tabular}

10.10 Data from Test 210

\begin{tabular}{|c|c|c|c|c|c|c|c|}
\hline $\begin{array}{c}\text { Reaction } \\
\text { Time }(\mathrm{h})\end{array}$ & $\begin{array}{c}\text { Soluble } \\
\text { NaTPB } \\
(\mathrm{mmol} / \mathrm{L})\end{array}$ & $\begin{array}{c}3 \mathrm{~PB} \\
(\mathrm{mmol} / \mathrm{L})\end{array}$ & $\begin{array}{c}2 \mathrm{~PB} \\
(\mathrm{mmol} / \mathrm{L})\end{array}$ & $\begin{array}{c}\text { 1PB } \\
(\mathrm{mmol} / \mathrm{L})\end{array}$ & $\begin{array}{c}\text { Phenol } \\
(\mathrm{mmol} / \mathrm{L})\end{array}$ & $\begin{array}{c}\text { Soluble } \\
\text { Boron } \\
(\mathrm{mmol} / \mathrm{L})\end{array}$ & $\begin{array}{c}\text { Soluble } \\
\text { Organic } \\
\text { Boron } \\
(\mathrm{mmol} / \mathrm{L})\end{array}$ \\
\hline 17 & 1.00 & 4.08 & 2.76 & 2.88 & 2.08 & 11.8 & 10.7 \\
\hline 93 & 1.16 & 4.05 & 2.55 & 2.80 & 2.25 & 11.4 & 10.6 \\
\hline 186 & 1.19 & 3.92 & 2.41 & 2.80 & 2.60 & 11.6 & 10.3 \\
\hline 253 & 1.18 & 4.03 & 2.30 & 3.15 & 2.87 & 12.1 & 10.7 \\
\hline 421 & 1.05 & 3.78 & 1.99 & 3.17 & 3.25 & 12.3 & 10.0 \\
\hline 587 & 1.14 & 3.91 & 1.66 & 3.21 & 3.47 & 12.1 & 9.9 \\
\hline 749 & 0.91 & 3.47 & 1.39 & 2.82 & 3.59 & 12.0 & 8.6 \\
\hline 914 & 1.02 & 3.56 & 1.29 & 4.82 & 4.21 & 13.6 & 10.7 \\
\hline 1244 & 1.04 & 3.58 & 1.03 & 2.77 & 6.21 & 11.3 & 8.4 \\
\hline 1408 & 1.01 & 3.49 & 1.03 & 2.75 & 5.15 & 12.6 & 8.3 \\
\hline 1621 & 1.15 & 3.49 & 1.30 & 2.79 & 10.269 & 12.6 & 8.7 \\
\hline 1929 & 1.01 & 3.30 & 1.20 & 2.52 & 6.24 & 14.5 & 8.0 \\
\hline 2288 & 0.99 & 3.01 & 1.29 & 2.62 & 6.67 & 14.5 & 7.9 \\
\hline 2598 & 1.12 & 3.25 & 1.53 & 0.23 & 8.18 & 15.8 & 6.1 \\
\hline 3268 & 1.03 & 3.97 & 2.44 & 2.93 & 8.11 & 18.9 & 10.4 \\
\hline 3990 & 1.09 & 4.63 & 3.69 & 3.66 & 9.84 & 22.0 & 13.1 \\
\hline
\end{tabular}


10.11 Data from Test 211

\begin{tabular}{|c|c|c|c|c|c|c|c|}
\hline $\begin{array}{c}\text { Reaction } \\
\text { Time }(\mathrm{h})\end{array}$ & $\begin{array}{c}\text { Soluble } \\
\text { NaTPB } \\
(\mathrm{mmol} / \mathrm{L})\end{array}$ & $\begin{array}{c}3 \mathrm{~PB} \\
(\mathrm{mmol} / \mathrm{L})\end{array}$ & $\begin{array}{c}2 \mathrm{~PB} \\
(\mathrm{mmol} / \mathrm{L})\end{array}$ & $\begin{array}{c}1 \mathrm{~PB} \\
(\mathrm{mmol} / \mathrm{L})\end{array}$ & $\begin{array}{c}\text { Phenol } \\
(\mathrm{mmol} / \mathrm{L})\end{array}$ & $\begin{array}{c}\text { Soluble } \\
\text { Boron } \\
(\mathrm{mmol} / \mathrm{L})\end{array}$ & $\begin{array}{c}\text { Soluble } \\
\text { Organic } \\
\text { Boron } \\
(\mathrm{mmol} / \mathrm{L})\end{array}$ \\
\hline 18 & 1.10 & 4.19 & 2.51 & 2.91 & 2.92 & 11.5 & 10.7 \\
\hline 67 & 1.13 & 4.23 & 1.57 & 2.90 & 3.32 & 12.1 & 9.8 \\
\hline 136 & 1.22 & 4.23 & 0.68 & 2.76 & 4.43 & 13.4 & 8.9 \\
\hline 301 & 1.01 & 4.39 & 0.44 & 1.71 & 5.13 & 14.5 & 7.6 \\
\hline 465 & 1.06 & 5.06 & 0.36 & 1.28 & 5.71 & 16.6 & 7.8 \\
\hline 628 & 1.00 & 5.27 & 0.40 & 0.84 & 6.08 & 19.2 & 7.5 \\
\hline 788 & 1.00 & 5.48 & 0.38 & 0.98 & 6.79 & 20.5 & 7.9 \\
\hline 954 & 0.98 & 5.39 & 0.41 & 0.64 & 7.24 & 24.0 & 7.4 \\
\hline 1119 & 1.04 & 5.60 & 0.44 & 0.89 & 7.95 & 21.3 & 8.0 \\
\hline 1283 & 0.94 & 5.26 & 0.39 & 0.70 & 8.10 & 29.3 & 7.3 \\
\hline 1497 & 0.97 & 5.51 & 0.43 & 0.69 & 9.17 & 30.1 & 7.6 \\
\hline 1807 & 1.00 & 4.90 & 0.39 & 0.61 & 9.78 & 37.0 & 6.9 \\
\hline 2164 & 1.03 & 4.57 & 0.23 & 0.39 & 11.06 & 40.3 & 6.2 \\
\hline 2473 & 1.11 & 4.55 & 0.26 & 0.31 & 11.57 & 46.7 & 6.2 \\
\hline 3142 & 1.02 & 4.22 & 0.15 & 0.21 & 13.79 & 54.6 & 5.6 \\
\hline 3863 & 0.76 & 3.38 & 0.12 & 0.16 & 14.80 & 62.7 & 4.4 \\
\hline
\end{tabular}

10.12 Data from Test 212

\begin{tabular}{|c|c|c|c|c|c|c|c|c|}
\hline $\begin{array}{c}\text { Reaction } \\
\text { Time }(\mathrm{h})\end{array}$ & $\begin{array}{c}\text { Soluble } \\
\text { NaTPB } \\
(\mathrm{mmol} / \mathrm{L})\end{array}$ & $\begin{array}{c}3 \mathrm{~PB} \\
(\mathrm{mmol} / \mathrm{L})\end{array}$ & $\begin{array}{c}2 \mathrm{~PB} \\
(\mathrm{mmol} / \mathrm{L})\end{array}$ & $\begin{array}{c}1 \mathrm{~PB} \\
(\mathrm{mmol} / \mathrm{L})\end{array}$ & $\begin{array}{c}\text { Phenol } \\
(\mathrm{mmol} / \mathrm{L})\end{array}$ & $\begin{array}{c}\text { Soluble } \\
\text { Boron } \\
(\mathrm{mmol} / \mathrm{L})\end{array}$ & $\begin{array}{c}\text { Soluble } \\
\text { Organic } \\
\text { Boron } \\
(\mathrm{mmol} / \mathrm{L})\end{array}$ & $\begin{array}{c}\text { Soluble } \\
\text { Potassium } \\
(\mathrm{mmol} / \mathrm{L})\end{array}$ \\
\hline 17 & 1.09 & 4.08 & 2.47 & 2.78 & 2.53 & 12.1 & 10.4 & \\
\hline 90 & 1.04 & 4.81 & 2.34 & 3.38 & 3.61 & 15.3 & 11.6 & \\
\hline 157 & 1.07 & 8.25 & 4.47 & 4.00 & 3.52 & 20.9 & 17.8 & \\
\hline 249 & 1.14 & 10.87 & 6.01 & 4.23 & 3.98 & 25.6 & 22.2 & \\
\hline 413 & 0.61 & 11.82 & 8.65 & 5.77 & 5.24 & 33.0 & 26.9 & \\
\hline 578 & $<0.03$ & 8.78 & 11.00 & 9.72 & 7.42 & 37.6 & 29.5 & \\
\hline 742 & $<0.03$ & 4.24 & 9.68 & 12.54 & 6.58 & 39.4 & 26.5 & \\
\hline 906 & $<0.03$ & 1.78 & 8.30 & 15.66 & 7.36 & 41.4 & 25.8 & \\
\hline 1070 & $<0.03$ & 0.76 & 11.95 & 16.13 & 7.88 & 41.3 & 28.9 & \\
\hline 1234 & $<0.03$ & $<0.04$ & 3.08 & 14.85 & 9.12 & 45.4 & 18.0 & 0.78 \\
\hline 1397 & 0.06 & $<0.04$ & 0.82 & 10.10 & 11.30 & 45.5 & 11.0 & 0.83 \\
\hline 1611 & $<0.03$ & $<0.04$ & 0.15 & 5.30 & 14.58 & 50.1 & 5.5 & 1.22 \\
\hline 1919 & $<0.03$ & $<0.04$ & 0.05 & 1.22 & 15.54 & 23.9 & 1.3 & 0.87 \\
\hline 2277 & $<0.03$ & $<0.04$ & 0.05 & 0.21 & 16.14 & 55.0 & 0.3 & 1.60 \\
\hline
\end{tabular}




\subsection{Data from Test 213}

\begin{tabular}{|c|c|c|c|c|c|c|c|}
\hline $\begin{array}{c}\text { Reaction } \\
\text { Time }(\mathrm{h})\end{array}$ & $\begin{array}{c}\text { Soluble } \\
\text { NaTPB } \\
(\mathrm{mmol} / \mathrm{L})\end{array}$ & $\begin{array}{c}3 \mathrm{~PB} \\
(\mathrm{mmol} / \mathrm{L})\end{array}$ & $\begin{array}{c}2 \mathrm{~PB} \\
(\mathrm{mmol} / \mathrm{L})\end{array}$ & $\begin{array}{c}1 \mathrm{~PB} \\
(\mathrm{mmo} / \mathrm{L})\end{array}$ & $\begin{array}{c}\text { Phenol } \\
(\mathrm{mmol} / \mathrm{L})\end{array}$ & $\begin{array}{c}\text { Soluble } \\
\text { Boron } \\
(\mathrm{mmol} / \mathrm{L})\end{array}$ & $\begin{array}{c}\text { Soluble } \\
\text { Organic } \\
\text { Boron } \\
(\mathrm{mmol} / \mathrm{L})\end{array}$ \\
\hline 16 & 20.54 & 4.39 & 2.62 & 2.54 & 2.20 & 15.8 & 30.1 \\
\hline 87 & 5.47 & 4.61 & 2.31 & 2.62 & 2.93 & 15.8 & 15.0 \\
\hline 157 & 5.39 & 4.52 & 1.82 & 2.77 & 3.22 & 16.0 & 14.5 \\
\hline 322 & 5.06 & 4.23 & 1.05 & 2.99 & 3.95 & 17.1 & 13.3 \\
\hline 487 & 5.15 & 4.21 & 0.66 & 2.26 & 4.57 & 16.9 & 12.3 \\
\hline 651 & 4.94 & 4.08 & 0.48 & 2.12 & 4.97 & 16.7 & 11.6 \\
\hline 811 & 5.25 & 4.06 & 0.34 & 3.53 & 5.31 & 17.2 & 13.2 \\
\hline 1140 & 5.19 & 3.94 & 0.18 & 1.21 & 5.93 & 17.4 & 10.5 \\
\hline 1521 & 4.40 & 4.04 & 0.20 & 0.88 & 6.62 & 14.6 & 9.5 \\
\hline 1830 & 4.95 & 3.80 & 0.16 & 0.73 & 6.35 & 20.2 & 9.6 \\
\hline 2190 & 5.44 & 4.04 & 0.14 & 0.53 & 7.48 & 21.1 & 10.1 \\
\hline 2501 & 5.41 & 4.21 & 0.15 & 0.39 & 7.38 & 21.1 & 10.2 \\
\hline 3169 & 5.29 & 4.06 & 0.14 & 0.35 & 7.94 & 23.6 & 9.8 \\
\hline 3890 & 5.49 & 3.98 & 0.14 & 0.18 & 7.90 & 31.9 & 9.8 \\
\hline
\end{tabular}

\subsection{Data from Test 214}

\begin{tabular}{|c|c|c|c|c|c|c|c|}
\hline $\begin{array}{c}\text { Reaction } \\
\text { Time }(\mathrm{h})\end{array}$ & $\begin{array}{c}\text { Soluble } \\
\text { NaTPB } \\
(\mathrm{mmol} / \mathrm{L})\end{array}$ & $\begin{array}{c}3 \mathrm{~PB} \\
(\mathrm{mmo} / \mathrm{L})\end{array}$ & $\begin{array}{c}2 \mathrm{~PB} \\
(\mathrm{mmol} / \mathrm{L})\end{array}$ & $\begin{array}{c}1 \mathrm{~PB} \\
(\mathrm{mmol} / \mathrm{L})\end{array}$ & $\begin{array}{c}\text { Phenol } \\
(\mathrm{mmol} / \mathrm{L})\end{array}$ & $\begin{array}{c}\text { Soluble } \\
\text { Boron } \\
(\mathrm{mmol} / \mathrm{L})\end{array}$ & $\begin{array}{c}\text { Soluble } \\
\text { Organic } \\
\text { Boron } \\
(\mathrm{mmol} / \mathrm{L})\end{array}$ \\
\hline 16 & 0.25 & 4.36 & -2.91 & 2.62 & 2.47 & 10.7 & 10.1 \\
\hline 87 & 0.22 & 4.35 & 2.38 & 2.90 & 2.66 & 10.8 & 9.9 \\
\hline 157 & 0.21 & 3.89 & 1.43 & 3.01 & 3.49 & 11.3 & 8.5 \\
\hline 322 & 0.15 & 3.80 & 0.68 & 2.93 & 4.31 & 11.6 & 7.6 \\
\hline 487 & 0.20 & 3.56 & 0.44 & 2.30 & 4.80 & 12.2 & 6.5 \\
\hline 651 & 0.16 & 3.48 & 0.35 & 1.82 & 5.31 & 11.9 & 5.8 \\
\hline 811 & 0.14 & 3.38 & 0.28 & & & 12.8 & 3.8 \\
\hline 1140 & 0.16 & 2.95 & 0.23 & 1.02 & 6.17 & 13.8 & 4.3 \\
\hline 1521 & 0.15 & 2.97 & 0.27 & 0.73 & 6.99 & 12.2 & 4.1 \\
\hline 1830 & 0.18 & 2.66 & 0.26 & 0.58 & 7.19 & 17.4 & 3.7 \\
\hline 2190 & 0.22 & 2.68 & 0.23 & 0.44 & 8.11 & 17.9 & 3.6 \\
\hline 2501 & 0.17 & 2.39 & 0.14 & 0.39 & 8.26 & 18.9 & 3.1 \\
\hline 3169 & 0.17 & 2.18 & 0.13 & 0.30 & 8.96 & 21.8 & 2.8 \\
\hline 3890 & 0.18 & 1.82 & 0.14 & 0.24 & 9.48 & 30.8 & 2.4 \\
\hline
\end{tabular}




\subsection{Data from Test 215}

\begin{tabular}{|c|c|c|c|c|c|c|c|}
\hline $\begin{array}{c}\text { Reaction } \\
\text { Time }(\mathrm{h})\end{array}$ & $\begin{array}{c}\text { Soluble } \\
\text { NaTPB } \\
(\mathrm{mmol} / \mathrm{L})\end{array}$ & $\begin{array}{c}3 \mathrm{~PB} \\
(\mathrm{mmol} / \mathrm{L})\end{array}$ & $\begin{array}{c}2 \mathrm{~PB} \\
(\mathrm{mmol} / \mathrm{L})\end{array}$ & $\begin{array}{c}1 \mathrm{~PB} \\
(\mathrm{mmol} / \mathrm{L})\end{array}$ & $\begin{array}{c}\text { Phenol } \\
(\mathrm{mmol} / \mathrm{L})\end{array}$ & $\begin{array}{c}\text { Soluble } \\
\text { Boron } \\
(\mathrm{mmol} / \mathrm{L})\end{array}$ & $\begin{array}{c}\text { Soluble } \\
\text { Organic } \\
\text { Boron } \\
(\mathrm{mmol} / \mathrm{L})\end{array}$ \\
\hline 16 & 5.64 & 4.37 & 2.60 & 2.54 & 2.32 & 15.9 & 15.2 \\
\hline 87 & 5.55 & 4.56 & 2.36 & 2.63 & 2.58 & 16.1 & 15.1 \\
\hline 157 & 5.46 & 4.42 & 1.98 & 2.80 & 2.92 & 16.8 & 14.6 \\
\hline 322 & 5.05 & 4.25 & 1.34 & 3.12 & 3.67 & 16.8 & 13.8 \\
\hline 487 & 5.31 & 4.27 & 0.96 & 2.65 & 4.14 & 17.1 & 13.2 \\
\hline 651 & 5.03 & 4.15 & 0.73 & 2.26 & 4.63 & 16.6 & 12.2 \\
\hline 811 & 5.32 & 4.12 & 0.54 & & & 17.4 & 10.0 \\
\hline 1140 & 4.97 & 3.70 & 0.30 & 1.59 & 5.34 & 17.3 & 10.6 \\
\hline 1521 & 5.29 & 4.14 & 0.24 & 1.21 & 6.47 & 15.5 & 10.9 \\
\hline 1830 & 5.10 & 3.89 & 0.19 & 0.94 & 6.46 & 20.3 & 10.1 \\
\hline 2190 & 5.48 & 4.05 & 0.15 & 0.70 & 7.16 & 20.8 & 10.4 \\
\hline 2501 & 5.53 & 4.37 & 0.14 & 0.51 & 7.17 & 21.8 & 10.5 \\
\hline 3169 & 5.34 & 4.25 & 0.14 & 0.37 & 8.15 & 23.9 & 10.1 \\
\hline 3890 & 5.36 & 3.95 & 0.14 & 0.21 & 7.95 & 031.3 & 9.7 \\
\hline
\end{tabular}

\subsection{Data from Test 216}

\begin{tabular}{|c|c|c|c|c|c|c|c|}
\hline $\begin{array}{c}\text { Reaction } \\
\text { Time }(\mathrm{h})\end{array}$ & $\begin{array}{c}\text { Soluble } \\
\text { NaTPB } \\
(\mathrm{mmo} / \mathrm{L})\end{array}$ & $\begin{array}{c}3 \mathrm{~PB} \\
(\mathrm{mmo} / \mathrm{L})\end{array}$ & $\begin{array}{c}2 \mathrm{~PB} \\
(\mathrm{mmol} / \mathrm{L})\end{array}$ & $\begin{array}{c}1 \mathrm{~PB} \\
(\mathrm{mmol} / \mathrm{L})\end{array}$ & $\begin{array}{c}\text { Phenol } \\
(\mathrm{mmol} / \mathrm{L})\end{array}$ & $\begin{array}{c}\text { Soluble } \\
\text { Boron } \\
(\mathrm{mmol} / \mathrm{L})\end{array}$ & $\begin{array}{c}\text { Soluble } \\
\text { Organic } \\
\text { Boron } \\
(\mathrm{mmol} / \mathrm{L})\end{array}$ \\
\hline 18 & 0.19 & 4.20 & 2.98 & 3.20 & 2.66 & 10.6 & 10.6 \\
\hline 65 & 0.20 & 4.22 & 2.62 & 2.73 & 2.75 & 10.6 & 9.8 \\
\hline 135 & 0.24 & 4.19 & 2.05 & 3.04 & 3.25 & 10.8 & 9.5 \\
\hline 300 & 0.18 & 3.99 & 1.02 & 3.03 & 4.35 & 12.0 & 8.2 \\
\hline 465 & 0.22 & 3.99 & 0.51 & 2.39 & 4.92 & 12.5 & 7.1 \\
\hline 629 & 0.16 & 3.94 & 0.38 & 1.88 & 5.45 & 12.3 & 6.4 \\
\hline 789 & 0.12 & 3.70 & 0.30 & 1.62 & 5.95 & 13.3 & 5.7 \\
\hline 1121 & 0.16 & 3.56 & 0.32 & 1.14 & 6.39 & 14.4 & 5.2 \\
\hline 1504 & 0.15 & 3.68 & 0.34 & 0.80 & 7.35 & 13.1 & 5.0 \\
\hline 1813 & 0.19 & 3.25 & 0.27 & 0.69 & 10.29 & 18.4 & 4.4 \\
\hline 2173 & 0.20 & 3.13 & 0.20 & 0.51 & 8.26 & 18.4 & 4.0 \\
\hline 2483 & 0.21 & 3.15 & 0.16 & 0.41 & 8.59 & 19.9 & 3.9 \\
\hline 3151 & 0.18 & 2.90 & 0.15 & 0.33 & 9.75 & 25.2 & 3.6 \\
\hline 3873 & 0.20 & 2.43 & 0.15 & 0.24 & 10.01 & 31.3 & 3.0 \\
\hline
\end{tabular}


10.17 Data from Test 217

\begin{tabular}{|c|c|c|c|c|c|c|c|}
\hline $\begin{array}{c}\text { Reaction } \\
\text { Time }(\mathrm{h})\end{array}$ & $\begin{array}{c}\text { Soluble } \\
\text { NaTPB } \\
(\mathrm{mmol} / \mathrm{L})\end{array}$ & $\begin{array}{c}3 \mathrm{~PB} \\
(\mathrm{mmol} / \mathrm{L})\end{array}$ & $\begin{array}{c}2 \mathrm{~PB} \\
(\mathrm{mmo} / \mathrm{L})\end{array}$ & $\begin{array}{c}\text { 1PB } \\
(\mathrm{mmol} / \mathrm{L})\end{array}$ & $\begin{array}{c}\text { Phenol } \\
(\mathrm{mmol} / \mathrm{L})\end{array}$ & $\begin{array}{c}\text { Soluble } \\
\text { Boron } \\
(\mathrm{mmol} / \mathrm{L})\end{array}$ & $\begin{array}{c}\text { Soluble } \\
\text { Organic } \\
\text { Boron } \\
(\mathrm{mmol} / \mathrm{L})\end{array}$ \\
\hline 17 & 5.86 & 4.49 & 2.78 & 2.83 & 2.00 & 15.9 & 16.0 \\
\hline 93 & 5.96 & 4.42 & 2.53 & 2.55 & 2.37 & 15.7 & 15.5 \\
\hline 186 & 5.91 & 4.51 & 2.41 & 2.53 & 2.56 & 16.1 & 15.4 \\
\hline 253 & 5.79 & 4.55 & 2.36 & 2.80 & 2.79 & 16.6 & 15.5 \\
\hline 421 & 5.88 & 4.51 & 2.02 & 2.79 & 3.30 & 17.2 & 15.2 \\
\hline 587 & 5.80 & 4.50 & 1.63 & 2.89 & 3.56 & 16.5 & 14.8 \\
\hline 749 & 5.31 & 4.25 & 1.41 & 2.62 & 3.83 & 15.7 & 13.6 \\
\hline 914 & 6.02 & 4.50 & 1.30 & 4.49 & 4.28 & 17.4 & 16.3 \\
\hline 1244 & 5.91 & 4.38 & 1.01 & 2.56 & 6.61 & 12.5 & 13.9 \\
\hline 1621 & 5.75 & 4.46 & 0.78 & 2.39 & 5.54 & 12.1 & 13.4 \\
\hline 1929 & 5.53 & 4.30 & 0.66 & 2.14 & 5.54 & 17.7 & 12.6 \\
\hline 2288 & 5.71 & 4.36 & 0.48 & 1.93 & 6.18 & 16.7 & 12.5 \\
\hline 2598 & 5.95 & 4.85 & 0.44 & 1.80 & 6.99 & 17.7 & 13.0 \\
\hline 3268 & 5.88 & 4.70 & 0.32 & 1.53 & 7.00 & 17.5 & 12.4 \\
\hline 3990 & 5.96 & 4.57 & 0.26 & 1.12 & 7.53 & $1 \mathrm{NA}$ & 11.9 \\
\hline & & & & & & & \\
\hline
\end{tabular}

\subsection{Data from Test 218}

\begin{tabular}{|c|c|c|c|c|c|c|c|}
\hline $\begin{array}{c}\text { Reaction } \\
\text { Time }(\mathrm{h})\end{array}$ & $\begin{array}{c}\text { Soluble } \\
\text { NaTPB } \\
(\mathrm{mmol} / \mathrm{L})\end{array}$ & $\begin{array}{c}3 \mathrm{~PB} \\
(\mathrm{mmol} / \mathrm{L})\end{array}$ & $\begin{array}{c}2 \mathrm{~PB} \\
(\mathrm{mmol} / \mathrm{L})\end{array}$ & $\begin{array}{c}1 \mathrm{~PB} \\
(\mathrm{mmol} / \mathrm{L})\end{array}$ & $\begin{array}{c}\text { Phenol } \\
(\mathrm{mmol} / \mathrm{L})\end{array}$ & $\begin{array}{c}\text { Soluble } \\
\text { Boron } \\
(\mathrm{mmol} / \mathrm{L})\end{array}$ & $\begin{array}{c}\text { Soluble } \\
\text { Organic } \\
\text { Boron } \\
(\mathrm{mmol} / \mathrm{L})\end{array}$ \\
\hline 17 & 0.19 & 4.20 & 3.01 & 2.73 & 2.05 & 10.1 & 10.1 \\
\hline 93 & 0.23 & 4.14 & 2.69 & 2.90 & 3.02 & 10.1 & 10.0 \\
\hline 186 & 0.23 & 4.21 & 2.52 & 2.90 & 2.91 & 10.5 & 9.9 \\
\hline 253 & 0.23 & 4.21 & 2.30 & 3.12 & 3.20 & 10.7 & 9.9 \\
\hline 421 & 0.21 & 4.04 & 1.93 & 3.05 & 3.69 & 11.4 & 9.2 \\
\hline 587 & 0.25 & 4.12 & 1.56 & 3.04 & 4.12 & 11.3 & 9.0 \\
\hline 749 & 0.16 & 3.82 & 1.32 & 2.76 & 4.43 & 11.1 & 8.1 \\
\hline 914 & 0.19 & 4.18 & 1.20 & 5.03 & 5.09 & 12.1 & 10.6 \\
\hline 1244 & 0.14 & 3.73 & 0.76 & 2.64 & 1.25 & 10.2 & 7.3 \\
\hline 1621 & 0.14 & 3.75 & 0.46 & 2.37 & 6.67 & 10.6 & 6.7 \\
\hline 1929 & 0.21 & 4.00 & 0.38 & 2.12 & 7.15 & 12.5 & 6.7 \\
\hline 2288 & 0.22 & 3.68 & 0.25 & 1.62 & 7.31 & 12.1 & 5.8 \\
\hline 2598 & 0.18 & 3.84 & 0.23 & 1.46 & 8.15 & 12.7 & 5.7 \\
\hline 3268 & 0.19 & 3.59 & 0.19 & 1.16 & 8.39 & 13.3 & 5.1 \\
\hline 3990 & 0.20 & 3.39 & 0.21 & 0.82 & 8.70 & 18.6 & 4.6 \\
\hline
\end{tabular}


10.19 Data from Test 219

\begin{tabular}{|c|c|c|c|c|c|c|c|}
\hline $\begin{array}{c}\text { Reaction } \\
\text { Time }(\mathrm{h})\end{array}$ & $\begin{array}{c}\text { Soluble } \\
\text { NaTPB } \\
(\mathrm{mmol} / \mathrm{L})\end{array}$ & $\begin{array}{c}3 \mathrm{~PB} \\
(\mathrm{mmol} / \mathrm{L})\end{array}$ & $\begin{array}{c}2 \mathrm{~PB} \\
(\mathrm{mmol} / \mathrm{L})\end{array}$ & $\begin{array}{c}\text { iPB } \\
(\mathrm{mmol} / \mathrm{L})\end{array}$ & $\begin{array}{c}\text { Phenol } \\
(\mathrm{mmol} / \mathrm{L})\end{array}$ & $\begin{array}{c}\text { Soluble } \\
\text { Boron } \\
(\mathrm{mmol} / \mathrm{L})\end{array}$ & $\begin{array}{c}\text { Soluble } \\
\text { Organic } \\
\text { Boron } \\
(\mathrm{mmol} / \mathrm{L})\end{array}$ \\
\hline 16 & 5.84 & 4.52 & 2.50 & 2.61 & 2.49 & 16.0 & 15.5 \\
\hline 87 & 5.46 & 4.46 & 1.49 & 2.27 & 3.42 & 16.1 & 13.7 \\
\hline 157 & 5.60 & 4.45 & 0.93 & 2.65 & 4.17 & 17.0 & 13.6 \\
\hline 322 & 5.28 & 4.12 & 0.51 & 2.26 & 5.12 & 17.7 & 12.2 \\
\hline 487 & 5.24 & 3.93 & 0.34 & 1.52 & 5.74 & 20.0 & 11.0 \\
\hline 651 & 5.19 & 3.80 & 0.28 & 0.98 & 6.41 & 19.9 & 10.2 \\
\hline 811 & 5.77 & 3.84 & 0.20 & 1.32 & 7.00 & 22.2 & 11.1 \\
\hline 1140 & 5.15 & 3.24 & 0.11 & 0.33 & 7.29 & 24.9 & 8.8 \\
\hline 1307 & 5.25 & 3.15 & 0.13 & 0.27 & 7.74 & 26.1 & 8.8 \\
\hline 1521 & 5.65 & 3.37 & 0.15 & 0.24 & 8.63 & 27.2 & 9.4 \\
\hline 1830 & 5.41 & 3.11 & 0.13 & 0.17 & 8.43 & 34.6 & 8.8 \\
\hline 2190 & 5.96 & 3.12 & 0.09 & 0.08 & 9.21 & 37.0 & 9.3 \\
\hline 2501 & 5.85 & 3.24 & 0.09 & 0.08 & 9.71 & 39.9 & 9.3 \\
\hline 3169 & 5.70 & 2.92 & 0.09 & 0.08 & 10.47 & 51.7 & 8.8 \\
\hline 3890 & 5.34 & 2.62 & 0.06 & 0.08 & 11.01 & 78.6 & 8.1 \\
\hline
\end{tabular}

10.20 Data from Test 220

\begin{tabular}{|c|c|c|c|c|c|c|c|}
\hline $\begin{array}{c}\text { Reaction } \\
\text { Time }(\mathrm{h})\end{array}$ & $\begin{array}{c}\text { Soluble } \\
\text { NaTPB } \\
(\mathrm{mmol} / \mathrm{L})\end{array}$ & $\begin{array}{c}3 \mathrm{~PB} \\
(\mathrm{mmol} / \mathrm{L})\end{array}$ & $\begin{array}{c}2 \mathrm{~PB} \\
(\mathrm{mmol} / \mathrm{L})\end{array}$ & $\begin{array}{c}\text { 1PB } \\
(\mathrm{mmol} / \mathrm{L})\end{array}$ & $\begin{array}{c}\text { Phenol } \\
(\mathrm{mmol} / \mathrm{L})\end{array}$ & $\begin{array}{c}\text { Soluble } \\
\text { Boron } \\
(\mathrm{mmol} / \mathrm{L})\end{array}$ & $\begin{array}{c}\text { Soluble } \\
\text { Organic } \\
\text { Boron } \\
(\mathrm{mmo} / \mathrm{L})\end{array}$ \\
\hline 17 & 0.26 & 4.06 & 2.61 & 2.68 & 2.48 & 11.2 & 9.6 \\
\hline 90 & 0.21 & 4.05 & 0.94 & 2.88 & 3.86 & 11.8 & 8.1 \\
\hline 157 & 0.25 & 4.15 & 0.49 & 2.43 & 4.65 & 11.9 & 7.3 \\
\hline 249 & 0.24 & 4.11 & $<0.05$ & 1.78 & 5.00 & 13.6 & 6.2 \\
\hline 413 & 0.18 & 4.22 & 0.40 & 1.21 & 5.57 & 15.8 & 6.0 \\
\hline 578 & 0.22 & 4.74 & 0.49 & 1.20 & 6.30 & 18.5 & 6.6 \\
\hline 742 & 0.20 & 5.51 & 0.57 & 0.93 & 6.72 & 21.8 & 7.2 \\
\hline 906 & 0.18 & 6.26 & 0.70 & 1.16 & 7.38 & 26.4 & 8.3 \\
\hline 1070 & 0.37 & 12.12 & 1.54 & 1.24 & 8.50 & 27.9 & 15.3 \\
\hline 1234 & 0.18 & 6.88 & 0.87 & 1.72 & 8.80 & 33.3 & 9.6 \\
\hline 1397 & 0.15 & 7.31 & 0.99 & 1.58 & 11.18 & 35.8 & 10.0 \\
\hline 1611 & 0.10 & $<0.04$ & 1.30 & 1.80 & 10.12 & 42.0 & 3.2 \\
\hline 1919 & 0.04 & 6.82 & 1.18 & 1.75 & 11.51 & 48.0 & 9.8 \\
\hline 2277 & 0.03 & 6.07 & 0.95 & 1.55 & 13.37 & 61.4 & 8.6 \\
\hline 2586 & 0.03 & 5.77 & 0.57 & 1.11 & 15.55 & 67.9 & 7.5 \\
\hline 3255 & 0.03 & 3.77 & 0.24 & 0.42 & 17.54 & 91.9 & 4.5 \\
\hline 3977 & 0.03 & 2.07 & 0.15 & 0.26 & 18.66 & 110.3 & 2.5 \\
\hline & & & & & & & \\
\hline
\end{tabular}


10.21 Data from Test 221

\begin{tabular}{|c|c|c|c|c|c|c|c|}
\hline $\begin{array}{c}\text { Reaction } \\
\text { Time }(\mathrm{h})\end{array}$ & $\begin{array}{c}\text { Soluble } \\
\text { NaTPB } \\
(\mathrm{mmol} / \mathrm{L})\end{array}$ & $\begin{array}{c}3 \mathrm{~PB} \\
(\mathrm{mmol} / \mathrm{L})\end{array}$ & $\begin{array}{c}2 \mathrm{~PB} \\
(\mathrm{mmol} / \mathrm{L})\end{array}$ & $\begin{array}{c}1 \mathrm{~PB} \\
(\mathrm{mmol} / \mathrm{L})\end{array}$ & $\begin{array}{c}\text { Phenol } \\
(\mathrm{mmol} / \mathrm{L})\end{array}$ & $\begin{array}{c}\text { Soluble } \\
\text { Boron } \\
(\mathrm{mmol} / \mathrm{L})\end{array}$ & $\begin{array}{c}\text { Soluble } \\
\text { Organic } \\
\text { Boron } \\
(\mathrm{mmol} / \mathrm{L})\end{array}$ \\
\hline 18 & 1.08 & 4.27 & 2.85 & 3.11 & 2.54 & 12.1 & 11.3 \\
\hline 67 & 1.06 & 4.27 & 2.38 & 2.76 & 2.53 & 11.5 & 10.5 \\
\hline 136 & 0.99 & 4.11 & 1.60 & 3.12 & 3.46 & 12.4 & 9.8 \\
\hline 300 & 0.89 & 4.06 & 0.81 & 3.19 & 4.05 & 12.5 & 9.0 \\
\hline 465 & 1.05 & 4.05 & 0.51 & 2.47 & 4.56 & 12.8 & 8.1 \\
\hline 628 & 1.00 & 3.73 & 0.32 & 1.73 & 5.04 & 12.8 & 6.8 \\
\hline 788 & 0.90 & 3.55 & 0.25 & 1.59 & $<0.11$ & 12.7 & 6.3 \\
\hline 1118 & 0.98 & 3.33 & 0.23 & 1.16 & 6.02 & 12.0 & 5.7 \\
\hline 1497 & 0.89 & 3.31 & 0.23 & 0.66 & 6.79 & 72.2 & 5.1 \\
\hline 1807 & 1.03 & 3.15 & 0.19 & 0.50 & 6.72 & 16.6 & 4.9 \\
\hline 2164 & 1.12 & 3.11 & 0.18 & 0.35 & 6.89 & 17.4 & 4.8 \\
\hline 2472 & 1.05 & 3.13 & 0.16 & 0.30 & 7.74 & 18.7 & 4.6 \\
\hline 3142 & 1.09 & 3.17 & 0.15 & 0.24 & 8.05 & 23.1 & 4.7 \\
\hline 3863 & 1.05 & 2.71 & .014 & 0.18 & 8.13 & 21.6 & 4.1 \\
\hline
\end{tabular}

10.22 Data from Test 222

\begin{tabular}{|c|c|c|c|c|c|c|c|}
\hline $\begin{array}{c}\text { Reaction } \\
\text { Time }(\mathrm{h})\end{array}$ & $\begin{array}{c}\text { Soluble } \\
\mathrm{NaTPB} \\
(\mathrm{mmol} / \mathrm{L})\end{array}$ & $\begin{array}{c}3 \mathrm{~PB} \\
(\mathrm{mmol} / \mathrm{L})\end{array}$ & $\begin{array}{c}2 \mathrm{~PB} \\
(\mathrm{mmol} / \mathrm{L})\end{array}$ & $\begin{array}{c}1 \mathrm{~PB} \\
(\mathrm{mmol} / \mathrm{L})\end{array}$ & $\begin{array}{c}\text { Phenol } \\
(\mathrm{mmol} / \mathrm{L})\end{array}$ & $\begin{array}{c}\text { Soluble } \\
\text { Boron } \\
(\mathrm{mmol} / \mathrm{L})\end{array}$ & $\begin{array}{c}\text { Soluble } \\
\text { Organic } \\
\text { Boron } \\
(\mathrm{mmol} / \mathrm{L})\end{array}$ \\
\hline 16 & 1.22 & 4.08 & 2.61 & 2.87 & 2.79 & 11.6 & 10.8 \\
\hline 87 & 1.07 & 4.18 & 2.28 & 2.73 & 2.75 & 11.7 & 10.3 \\
\hline 157 & 1.05 & 4.04 & 1.81 & 3.03 & 3.42 & 11.8 & 9.9 \\
\hline 322 & 0.92 & 3.75 & 1.34 & 3.08 & 4.19 & 13.0 & 9.1 \\
\hline 487 & 1.00 & 3.61 & 1.39 & 2.94 & 4.96 & 14.2 & 8.9 \\
\hline 651 & 0.85 & 3.91 & 2.24 & 3.51 & 5.77 & 16.1 & 10.5 \\
\hline 811 & 0.81 & 6.80 & 4.08 & 3.81 & 5.98 & 22.2 & 15.5 \\
\hline 976 & 0.75 & 9.48 & 6.24 & 4.07 & 7.29 & 26.8 & 20.5 \\
\hline 1140 & 0.65 & 10.39 & 7.14 & 4.31 & 5.91 & 30.9 & 22.5 \\
\hline 1307 & 0.43 & 11.32 & 8.97 & 5.14 & 9.98 & 34.1 & 25.9 \\
\hline 1521 & 0.08 & 10.62 & 9.69 & 7.47 & 7.66 & 33.1 & 27.9 \\
\hline 1830 & 0.03 & 7.62 & 7.68 & 9.61 & 18.69 & 38.4 & 24.9 \\
\hline 2190 & 0.03 & 6.03 & 4.32 & 9.78 & 10.82 & 40.1 & 20.2 \\
\hline 2501 & 0.03 & 6.03 & 2.26 & 8.34 & 12.84 & 40.5 & 16.7 \\
\hline
\end{tabular}




\subsection{Data from Test 223}

\begin{tabular}{|c|c|c|c|c|c|c|c|}
\hline $\begin{array}{c}\text { Reaction } \\
\text { Time }(\mathrm{h})\end{array}$ & $\begin{array}{c}\text { Soluble } \\
\text { NaTPB } \\
(\mathrm{mmol} / \mathrm{L})\end{array}$ & $\begin{array}{c}3 \mathrm{~PB} \\
(\mathrm{mmol} / \mathrm{L})\end{array}$ & $\begin{array}{c}2 \mathrm{~PB} \\
(\mathrm{mmol} / \mathrm{L})\end{array}$ & $\begin{array}{c}1 \mathrm{~PB} \\
(\mathrm{mmo} / \mathrm{L})\end{array}$ & $\begin{array}{c}\text { Phenol } \\
(\mathrm{mmol} / \mathrm{L})\end{array}$ & $\begin{array}{c}\text { Soluble } \\
\text { Boron } \\
(\mathrm{mmol} / \mathrm{L})\end{array}$ & $\begin{array}{c}\text { Soluble } \\
\text { Organic } \\
\text { Boron } \\
(\mathrm{mmol} / \mathrm{L})\end{array}$ \\
\hline 18 & 1.12 & 4.27 & 2.84 & 3.12 & 2.58 & 11.8 & 11.3 \\
\hline 67 & 1.12 & 4.33 & 2.47 & 2.70 & 2.52 & 11.6 & 10.6 \\
\hline 136 & 1.12 & 4.18 & 2.01 & 3.06 & 3.17 & 12.5 & 10.4 \\
\hline 300 & 1.03 & 4.25 & 0.71 & 3.16 & 4.03 & 13.1 & 9.2 \\
\hline 465 & 1.06 & 4.38 & 0.52 & 2.70 & 4.49 & 13.0 & 8.7 \\
\hline 628 & 1.01 & 4.24 & 0.38 & 1.83 & 4.81 & 13.5 & 7.5 \\
\hline 788 & 0.94 & 4.19 & 0.32 & 1.66 & 5.19 & 13.5 & 7.1 \\
\hline 1118 & 1.02 & 4.12 & 0.33 & 1.23 & 5.77 & 10.5 & 6.7 \\
\hline 1497 & 0.91 & 4.20 & 0.35 & 0.84 & 6.63 & 79.4 & 6.3 \\
\hline 1807 & 1.02 & 4.16 & 0.31 & 0.68 & 6.36 & 18.9 & 6.2 \\
\hline 2164 & 1.10 & 4.28 & 0.30 & 0.85 & 7.25 & 19.3 & 6.5 \\
\hline 2472 & 1.16 & 4.45 & 0.25 & 0.44 & 7.31 & 21.0 & 6.3 \\
\hline 3142 & 1.14 & 4.41 & 0.19 & 0.30 & 8.38 & 26.2 & 6.0 \\
\hline 3863 & 1.06 & 3.84 & 0.15 & 0.21 & 8.64 & 23.8 & 5.3 \\
\hline
\end{tabular}

\subsection{Data from Test 224}

\begin{tabular}{|c|c|c|c|c|c|c|c|c|}
\hline $\begin{array}{c}\text { Reaction } \\
\text { Time }(\mathrm{h})\end{array}$ & $\begin{array}{c}\text { Soluble } \\
\text { NaTPB } \\
(\mathrm{mmol} / \mathrm{L})\end{array}$ & $\begin{array}{c}3 \mathrm{~PB} \\
(\mathrm{mmol} / \mathrm{L})\end{array}$ & $\begin{array}{c}2 \mathrm{~PB} \\
(\mathrm{mmol} / \mathrm{L})\end{array}$ & $\begin{array}{c}1 \mathrm{~PB} \\
(\mathrm{mmol} / \mathrm{L})\end{array}$ & $\begin{array}{c}\text { Phenol } \\
(\mathrm{mmol})\end{array}$ & $\begin{array}{c}\text { Soluble } \\
\text { Boron } \\
(\mathrm{mmol} / \mathrm{L})\end{array}$ & $\begin{array}{c}\text { Soluble } \\
\text { Organic } \\
\text { Boron } \\
(\mathrm{mmol} / \mathrm{L})\end{array}$ & $\begin{array}{c}\text { Soluble } \\
\text { Potassium } \\
(\mathrm{mmol} / \mathrm{L})\end{array}$ \\
\hline 16 & 1.22 & 4.04 & 2.57 & 2.99 & 2.82 & 11.6 & 10.8 & \\
\hline 87 & 1.14 & 4.13 & 2.40 & 2.76 & 2.64 & 11.5 & 10.4 & \\
\hline 157 & 1.20 & 4.15 & 2.04 & 3.21 & 3.20 & 11.7 & 10.6 & \\
\hline 322 & 0.91 & 4.77 & 2.43 & 3.89 & 4.21 & 15.8 & 12.0 & \\
\hline 487 & 0.95 & 8.52 & 4.76 & 4.26 & 4.25 & 23.1 & 18.5 & \\
\hline 651 & 0.79 & 10.72 & 6.91 & 4.47 & 4.49 & 26.8 & 22.8 & \\
\hline 811 & 0.67 & 12.22 & 8.29 & & & 31.5 & 21.2 & \\
\hline 976 & 0.27 & 12.75 & 10.47 & 6.39 & 6.66 & 36.7 & 29.9 & \\
\hline 1140 & $<0.03$ & 9.30 & 11.10 & 6.97 & 5.13 & 35.5 & 27.4 & $<2.16$ \\
\hline 1307 & $<0.03$ & 7.26 & 12.25 & 8.40 & 7.37 & 35.8 & 27.9 & 0.00 \\
\hline 1521 & $<0.03$ & 5.24 & 13.38 & 11.08 & 6.72 & 33.7 & 29.7 & 0.12 \\
\hline 1830 & $<0.03$ & 2.86 & 9.81 & 13.69 & 10.24 & 40.5 & 26.4 & 0.25 \\
\hline 2190 & $<0.03$ & 1.88 & 4.40 & 13.49 & 10.75 & 39.1 & 19.8 & 0.20 \\
\hline 2501 & $<0.03$ & 1.65 & 1.85 & 10.69 & 12.78 & 40.5 & 14.2 & 0.25 \\
\hline
\end{tabular}


10.25 Data from Test 225

\begin{tabular}{|c|c|c|c|c|c|c|c|}
\hline $\begin{array}{c}\text { Reaction } \\
\text { Time (h) }\end{array}$ & $\begin{array}{c}\text { Soluble } \\
\text { NaTPB } \\
(\mathrm{mmol} / \mathrm{L})\end{array}$ & $\begin{array}{c}3 \mathrm{~PB} \\
(\mathrm{mmol} / \mathrm{L})\end{array}$ & $\begin{array}{c}2 \mathrm{~PB} \\
(\mathrm{mmol} / \mathrm{L})\end{array}$ & $\begin{array}{c}1 \mathrm{~PB} \\
(\mathrm{mmol} / \mathrm{L})\end{array}$ & $\begin{array}{c}\text { Phenol } \\
(\mathrm{mmol} / \mathrm{L})\end{array}$ & $\begin{array}{c}\text { Soluble } \\
\text { Boron } \\
(\mathrm{mmol} / \mathrm{L})\end{array}$ & $\begin{array}{c}\text { Soluble } \\
\text { Organic } \\
\text { Boron } \\
(\mathrm{mmol} / \mathrm{L})\end{array}$ \\
\hline 16 & 1.25 & 4.27 & 2.72 & 2.58 & 2.56 & 11.6 & 10.8 \\
\hline 87 & 1.22 & 4.40 & 2.31 & 2.80 & 2.62 & 11.5 & 10.7 \\
\hline 157 & 1.09 & 4.25 & 1.86 & 2.85 & 3.12 & 12.2 & 10.1 \\
\hline 322 & 0.99 & 4.02 & 0.90 & 2.92 & 3.98 & 12.8 & 8.8 \\
\hline 487 & 1.15 & 4.06 & 0.49 & 2.27 & 4.74 & 13.4 & 8.0 \\
\hline 651 & 1.04 & 3.97 & 0.35 & 1.82 & 5.15 & 12.7 & 7.2 \\
\hline 811 & 1.07 & 3.89 & 0.26 & 1.70 & 5.84 & 13.6 & 6.9 \\
\hline 1140 & 1.01 & 3.42 & 0.19 & 0.98 & 6.62 & 15.0 & 5.6 \\
\hline 1521 & 0.98 & 33.74 & 0.21 & 0.60 & 6.99 & 17.3 & 5.5 \\
\hline 1830 & 1.08 & 3.42 & 0.23 & 0.46 & 9.58 & 17.9 & 5.2 \\
\hline 2190 & 1.06 & 3.32 & 0.19 & 0.36 & 7.69 & 17.9 & 4.9 \\
\hline 2501 & 1.25 & 3.81 & 0.16 & 0.30 & 8.11 & 19.3 & 5.5 \\
\hline 3169 & 1.08 & 3.44 & 0.14 & 0.23 & 8.55 & 24.1 & 4.9 \\
\hline 3890 & 1.15 & 3.09 & 0.16 & 0.19 & 8.69 & 29.6 & 4.6 \\
\hline
\end{tabular}

\subsection{Data from Test 226}

\begin{tabular}{|c|c|c|c|c|c|c|c|}
\hline $\begin{array}{c}\text { Reaction } \\
\text { Time (h) }\end{array}$ & $\begin{array}{c}\text { Soluble } \\
\text { NaTPB } \\
(\mathrm{mmol} / \mathrm{L})\end{array}$ & $\begin{array}{c}3 \mathrm{~PB} \\
(\mathrm{mmo} / \mathrm{L})\end{array}$ & $\begin{array}{c}2 \mathrm{~PB} \\
(\mathrm{mmol} / \mathrm{L})\end{array}$ & $\begin{array}{c}\text { 1PB } \\
(\mathrm{mmol} / \mathrm{L})\end{array}$ & $\begin{array}{c}\text { Phenol } \\
(\mathrm{mmol} / \mathrm{L})\end{array}$ & $\begin{array}{c}\text { Soluble } \\
\text { Boron } \\
(\mathrm{mmo} / \mathrm{L})\end{array}$ & $\begin{array}{c}\text { Soluble } \\
\text { Organic } \\
\text { Boron } \\
(\mathrm{mmol} / \mathrm{L})\end{array}$ \\
\hline 16 & 1.19 & 4.26 & 2.74 & 2.48 & 2.54 & 11.3 & 10.7 \\
\hline 87 & 1.18 & 4.60 & 2.34 & 2.80 & 2.79 & 11.5 & 10.9 \\
\hline 157 & 1.03 & 4.27 & 1.92 & 2.96 & 3.39 & 11.6 & 10.2 \\
\hline 322 & 0.98 & 4.12 & 1.09 & 2.91 & 4.15 & 12.7 & 9.1 \\
\hline 487 & 1.19 & 4.23 & 0.70 & 2.46 & 4.88 & 13.8 & 8.6 \\
\hline 651 & 0.98 & 3.88 & 0.52 & 2.16 & 5.34 & 12.9 & 7.5 \\
\hline 811 & 1.10 & 4.04 & 0.39 & 1.87 & 5.80 & 13.3 & 7.4 \\
\hline 1140 & 0.99 & 3.38 & 0.15 & 1.14 & 7.09 & 14.2 & 5.7 \\
\hline 1521 & 1.03 & 3.54 & 0.19 & 0.66 & 7.36 & 17.4 & 5.4 \\
\hline 1830 & 1.06 & 3.33 & 0.19 & 0.47 & 10.15 & 18.2 & 5.0 \\
\hline 2190 & 1.12 & 3.20 & 0.17 & 0.34 & 8.00 & 18.0 & 4.8 \\
\hline 2501 & 1.18 & 3.46 & 0.05 & 0.27 & 8.20 & 19.4 & 5.0 \\
\hline 3169 & 1.10 & 3.30 & 0.14 & 0.21 & 9.14 & 25.1 & 4.7 \\
\hline 3890 & 1.19 & 2.96 & 0.18 & 0.019 & 9.50 & 29.4 & 4.5 \\
\hline
\end{tabular}




\subsection{Data from Test 227}

\begin{tabular}{|c|c|c|c|c|c|c|c|}
\hline $\begin{array}{c}\text { Reaction } \\
\text { Time }(\mathrm{h})\end{array}$ & $\begin{array}{c}\text { Soluble } \\
\text { NaTPB } \\
(\mathrm{mmol} / \mathrm{L})\end{array}$ & $\begin{array}{c}3 \mathrm{~PB} \\
(\mathrm{mmol} / \mathrm{L})\end{array}$ & $\begin{array}{c}2 \mathrm{~PB} \\
(\mathrm{mmol} / \mathrm{L})\end{array}$ & $\begin{array}{c}1 \mathrm{~PB} \\
(\mathrm{mmo} / \mathrm{L})\end{array}$ & $\begin{array}{c}\text { Phenol } \\
(\mathrm{mmol} / \mathrm{L})\end{array}$ & $\begin{array}{c}\text { Soluble } \\
\text { Boron } \\
(\mathrm{mmol} / \mathrm{L})\end{array}$ & $\begin{array}{c}\text { Soluble } \\
\text { Organic } \\
\text { Boron } \\
(\mathrm{mmol} / \mathrm{L})\end{array}$ \\
\hline 16 & 1.24 & 4.25 & 2.76 & 2.57 & 2.64 & 12.3 & 10.8 \\
\hline 87 & 1.14 & 4.39 & 2.35 & 2.82 & 2.59 & 11.5 & 10.7 \\
\hline 157 & 1.08 & 4.24 & 1.84 & 3.00 & 3.13 & 12.0 & 10.2 \\
\hline 322 & 0.97 & 3.96 & 1.08 & 2.85 & 3.91 & 12.7 & 8.9 \\
\hline 487 & 1.16 & 4.14 & 0.53 & 2.34 & 4.71 & 13.5 & 8.2 \\
\hline 651 & 1.08 & 3.93 & 0.35 & 1.88 & 5.29 & 13.5 & 7.2 \\
\hline 811 & 1.02 & 3.82 & 0.27 & 1.64 & 5.70 & 13.8 & 6.7 \\
\hline 1140 & 1.00 & 3.39 & 0.15 & 0.95 & 7.31 & 14.9 & 5.5 \\
\hline 1521 & 0.94 & 3.53 & 0.19 & 0.58 & 7.12 & 17.0 & 5.2 \\
\hline 1830 & 1.07 & 3.35 & 0.19 & 0.47 & 9.92 & 18.7 & 5.1 \\
\hline 2190 & 1.10 & 3.26 & 0.19 & 0.32 & 7.76 & 18.1 & 4.9 \\
\hline 2501 & 1.27 & 3.58 & 0.14 & 0.27 & 8.20 & 19.9 & 5.3 \\
\hline 3169 & 1.08 & 3.37 & 0.14 & 0.25 & 9.06 & 25.4 & 4.8 \\
\hline 3890 & 1.11 & 2.92 & 0.15 & 0.17 & 9.31 & 31.4 & 4.4 \\
\hline
\end{tabular}

\subsection{Data from Test 228}

\begin{tabular}{|c|c|c|c|c|c|c|c|c|}
\hline $\begin{array}{c}\text { Reaction } \\
\text { Time }(\mathrm{h})\end{array}$ & $\begin{array}{c}\text { Soluble } \\
\text { NaTPB } \\
(\mathrm{mmol} / \mathrm{L})\end{array}$ & $\begin{array}{c}3 \mathrm{~PB} \\
(\mathrm{mmo} / \mathrm{L})\end{array}$ & $\begin{array}{c}2 \mathrm{~PB} \\
(\mathrm{mmol} / \mathrm{L})\end{array}$ & $\begin{array}{c}1 \mathrm{~PB} \\
(\mathrm{mmol} / \mathrm{L})\end{array}$ & $\begin{array}{c}\text { Phenol } \\
(\mathrm{mmol} / \mathrm{L})\end{array}$ & $\begin{array}{c}\text { Soluble } \\
\text { Boron } \\
(\mathrm{mmol} / \mathrm{L})\end{array}$ & $\begin{array}{c}\text { Soluble } \\
\text { Organic } \\
\text { Boron } \\
(\mathrm{mmol} / \mathrm{L})\end{array}$ & $\begin{array}{c}\text { Soluble } \\
\text { Potassium } \\
(\mathrm{mmol} / \mathrm{L})\end{array}$ \\
\hline 16 & 1.14 & 4.27 & 2.75 & 2.53 & 2.21 & 11.7 & 10.7 & \\
\hline 87 & 1.13 & 4.14 & 2.16 & 2.86 & 2.81 & 11.4 & 10.3 & \\
\hline 157 & 1.08 & 3.99 & 1.58 & 3.16 & 3.58 & 12.0 & 9.8 & \\
\hline 322 & 1.00 & 4.34 & 1.79 & 3.15 & 4.28 & 14.1 & 10.3 & \\
\hline 487 & 0.90 & 6.85 & 4.20 & 3.63 & 4.76 & 21.2 & 15.6 & \\
\hline 651 & 0.78 & 8.78 & 6.24 & 4.93 & 5.17 & 25.0 & 20.7 & \\
\hline 811 & 0.63 & 10.70 & 7.20 & 5.94 & 6.27 & 30.3 & 24.5 & \\
\hline 976 & 0.21 & 10.48 & 9.27 & 7.07 & 7.90 & 33.2 & 27.0 & \\
\hline 1140 & $<0.03$ & 8.26 & 10.95 & 8.50 & 6.16 & 35.4 & 27.7 & $<2.24$ \\
\hline 1307 & $<0.03$ & 5.49 & 11.01 & 10.04 & 6.60 & 37.2 & 26.6 & \\
\hline 1521 & $<0.03$ & 3.52 & 11.25 & 12.79 & 7.79 & 36.7 & 27.6 & 0.13 \\
\hline 1830 & $<0.03$ & 2.198 & 6.08 & 13.79 & 11.03 & 40.8 & 22.1 & 0.27 \\
\hline 2190 & $<0.03$ & 1.59 & 2.53 & 11.62 & 11.45 & 38.7 & 15.8 & \\
\hline 2501 & $<0.03$ & 1.43 & 1.09 & 8.74 & 13.80 & 40.5 & 11.3 & 0.28 \\
\hline
\end{tabular}


10.29 Data from Test 229

\begin{tabular}{|c|c|c|c|c|c|c|c|}
\hline $\begin{array}{c}\text { Reaction } \\
\text { Time }(\mathrm{h})\end{array}$ & $\begin{array}{c}\text { Soluble } \\
\text { NaTPB } \\
(\mathrm{mmol} / \mathrm{L})\end{array}$ & $\begin{array}{c}3 \mathrm{~PB} \\
(\mathrm{mmol} / \mathrm{L})\end{array}$ & $\begin{array}{c}2 \mathrm{~PB} \\
(\mathrm{mmol} / \mathrm{L})\end{array}$ & $\begin{array}{c}1 \mathrm{~PB} \\
(\mathrm{mmol} / \mathrm{L})\end{array}$ & $\begin{array}{c}\text { Phenol } \\
(\mathrm{mmol} / \mathrm{L})\end{array}$ & $\begin{array}{c}\text { Soluble } \\
\text { Boron } \\
(\mathrm{mmol} / \mathrm{L})\end{array}$ & $\begin{array}{c}\text { Soluble } \\
\text { Organic } \\
\text { Boron } \\
(\mathrm{mmol} / \mathrm{L})\end{array}$ \\
\hline 18 & 0.97 & 4.04 & 2.70 & 3.75 & 2.87 & 11.9 & 11.5 \\
\hline 69 & 0.86 & 4.05 & 2.43 & 2.96 & 2.83 & 11.7 & 10.3 \\
\hline 141 & 0.77 & 4.17 & 3.15 & 3.99 & 3.70 & 14.9 & 12.1 \\
\hline 309 & 0.70 & 4.72 & 6.29 & 5.04 & 3.46 & 20.3 & 16.8 \\
\hline 473 & 0.53 & 4.29 & 3.67 & 6.28 & 4.91 & 22.5 & 14.8 \\
\hline 641 & 0.38 & 3.46 & 2.26 & 5.89 & 6.30 & 24.2 & 12.0 \\
\hline 810 & 0.33 & 3.28 & 1.86 & 5.68 & 8.13 & 27.3 & 11.2 \\
\hline 978 & 0.56 & 3.58 & 1.29 & 4.66 & 10.18 & 30.7 & 10.1 \\
\hline 1145 & 0.40 & 3.48 & 1.45 & 4.69 & 11.37 & 28.5 & 10.0 \\
\hline 1314 & 0.23 & 3.18 & 1.71 & 4.49 & 12.57 & 35.7 & 9.6 \\
\hline 1530 & 0.31 & 3.31 & 1.98 & 4.83 & 15.28 & 39.5 & 10.4 \\
\hline 1841 & 0.19 & 2.62 & 2.41 & 4.95 & 15.05 & 50.2 & 10.2 \\
\hline 2199 & 0.07 & 1.40 & 2.44 & 5.97 & 19.60 & 71.5 & 9.9 \\
\hline 2507 & 0.03 & 0.36 & 2.34 & 7.33 & 21.74 & 91.0 & 10.1 \\
\hline
\end{tabular}

\subsection{Data from Test 230}

\begin{tabular}{|c|c|c|c|c|c|c|c|}
\hline $\begin{array}{c}\text { Reaction } \\
\text { Time }(\mathrm{h})\end{array}$ & $\begin{array}{c}\text { Soluble } \\
\text { NaTPB } \\
(\mathrm{mmol} / \mathrm{L})\end{array}$ & $\begin{array}{c}3 \mathrm{~PB} \\
(\mathrm{mmol} / \mathrm{L})\end{array}$ & $\begin{array}{c}2 \mathrm{~PB} \\
(\mathrm{mmol} / \mathrm{L})\end{array}$ & $\begin{array}{c}1 \mathrm{~PB} \\
(\mathrm{mmol} / \mathrm{L})\end{array}$ & $\begin{array}{c}\text { Phenol } \\
(\mathrm{mmol} / \mathrm{L})\end{array}$ & $\begin{array}{c}\text { Soluble } \\
\text { Boron } \\
(\mathrm{mmo} / \mathrm{L})\end{array}$ & $\begin{array}{c}\text { Soluble } \\
\text { Organic } \\
\text { Boron } \\
(\mathrm{mmol} / \mathrm{L})\end{array}$ \\
\hline 18 & 0.97 & 4.08 & 2.71 & 3.94 & 3.07 & 12.3 & 11.7 \\
\hline 69 & 0.93 & 4.02 & 2.40 & 3.17 & 2.94 & 11.7 & 10.5 \\
\hline 141 & 0.76 & 0.31 & 4.82 & 3.94 & 3.80 & 14.5 & 9.8 \\
\hline 309 & 0.40 & 5.77 & 6.16 & 5.76 & 3.95 & 23.9 & 18.1 \\
\hline 473 & 0.51 & 5.10 & 4.57 & 7.21 & 4.97 & 26.5 & 17.4 \\
\hline 641 & 0.40 & 4.49 & 2.99 & 6.98 & 5.99 & 28.7 & 14.9 \\
\hline 810 & 0.44 & 4.44 & 2.73 & 6.65 & 7.34 & 30.7 & 14.3 \\
\hline 978 & 0.48 & 4.05 & 2.63 & 6.07 & 8.21 & 33.4 & 13.2 \\
\hline 1145 & 0.49 & 3.81 & 2.49 & 6.54 & 9.35 & 27.0 & 13.3 \\
\hline 1314 & 0.71 & 3.86 & 2.54 & 6.46 & 10.54 & 40.1 & 13.6 \\
\hline 1530 & 0.51 & 3.55 & 2.70 & 6.51 & 13.06 & 37.8 & 13.3 \\
\hline 1841 & 0.29 & 2.93 & 2.93 & 6.78 & 13.01 & 48.2 & 12.9 \\
\hline 2199 & 0.12 & 1.64 & 3.09 & 6.62 & 14.47 & 51.8 & 11.5 \\
\hline 2507 & 0.10 & 0.90 & 3.20 & 7.32 & 16.18 & 61.1 & 11.5 \\
\hline
\end{tabular}


10.31 Data from Test 231

\begin{tabular}{|c|c|c|c|c|c|c|c|c|}
\hline $\begin{array}{c}\text { Reaction } \\
\text { Time }(\mathrm{h})\end{array}$ & $\begin{array}{c}\text { Soluble } \\
\text { NaTPB } \\
(\mathrm{mmm} / \mathrm{L})\end{array}$ & $\begin{array}{c}3 \mathrm{PPB} \\
(\mathrm{mmo} / \mathrm{L})\end{array}$ & $\begin{array}{c}2 \mathrm{~PB} \\
(\mathrm{~mm} / \mathrm{L})\end{array}$ & $\begin{array}{c}1 \mathrm{~PB} \\
(\mathrm{mmol} / \mathrm{L})\end{array}$ & $\begin{array}{c}\text { Phenol } \\
(\mathrm{mmol} / \mathrm{L})\end{array}$ & $\begin{array}{c}\text { Soluble } \\
\text { Boron } \\
(\mathrm{mmo} / \mathrm{L})\end{array}$ & $\begin{array}{c}\text { Soluble } \\
\text { Organic } \\
\text { Boron } \\
(\mathrm{mmol} / \mathrm{L})\end{array}$ & $\begin{array}{c}\text { Soluble } \\
\text { Potassium } \\
(\mathrm{mmo} / \mathrm{L})\end{array}$ \\
\hline 16 & 1.34 & 4.12 & 2.60 & 2.99 & 2.88 & 12.0 & 11.1 & \\
\hline 87 & 1.20 & 4.05 & 2.49 & 2.98 & 2.71 & 11.7 & 10.7 & \\
\hline 157 & 1.13 & 4.06 & 2.57 & 3.55 & 3.49 & 12.7 & 11.3 & \\
\hline 322 & 0.91 & 9.81 & 4.97 & 3.94 & 4.11 & 22.4 & 19.6 & \\
\hline 487 & 0.98 & 11.62 & 5.99 & 4.58 & 3.92 & 24.9 & 23.2 & \\
\hline 651 & 0.83 & 12.69 & 6.98 & 4.90 & 4.28 & 28.4 & 25.4 & \\
\hline 811 & 0.66 & 13.80 & 8.18 & 5.38 & 5.16 & 31.9 & 28.0 & \\
\hline 976 & 0.40 & 14.22 & 9.42 & 5.36 & 5.19 & 34.1 & 29.4 & \\
\hline 1140 & 0.07 & 12.07 & 10.03 & 5.80 & 3.73 & 35.3 & 28.0 & \\
\hline 1307 & $<0.03$ & 10.18 & 11.09 & 7.61 & 7.62 & 31.8 & 28.9 & 0.00 \\
\hline 1521 & $<0.03$ & 8.96 & 10.04 & 10.26 & 6.82 & 38.1 & 29.3 & 0.09 \\
\hline 1830 & $<0.03$ & 6.52 & 5.72 & 11.61 & 15.30 & 40.7 & 23.9 & 0.19 \\
\hline 2190 & $<0.03$ & 5.54 & 3.13 & 10.25 & 10.369 & 37.1 & 19.0 & 0.12 \\
\hline 2501 & $<0.03$ & 5.04 & 1.59 & 7.93 & 12.18 & 41.4 & 14.6 & 0.17 \\
\hline
\end{tabular}

\subsection{Data from Test 232}

\begin{tabular}{|c|c|c|c|c|c|c|c|}
\hline $\begin{array}{c}\text { Reaction } \\
\text { Time }(\mathrm{h})\end{array}$ & $\begin{array}{c}\text { Soluble } \\
\text { NaTPB } \\
(\mathrm{mmol} / \mathrm{L})\end{array}$ & $\begin{array}{c}3 \mathrm{~PB} \\
(\mathrm{mmol} / \mathrm{L})\end{array}$ & $\begin{array}{c}2 \mathrm{~PB} \\
(\mathrm{mmol} / \mathrm{L})\end{array}$ & $\begin{array}{c}1 \mathrm{~PB} \\
(\mathrm{mmol} / \mathrm{L})\end{array}$ & $\begin{array}{c}\text { Phenol } \\
(\mathrm{mmol} / \mathrm{L})\end{array}$ & $\begin{array}{c}\text { Soluble } \\
\text { Boron } \\
(\mathrm{mmo} / \mathrm{L})\end{array}$ & $\begin{array}{c}\text { Soluble } \\
\text { Organic } \\
\text { Boron } \\
(\mathrm{mmol} / \mathrm{L})\end{array}$ \\
\hline 18 & 25.01 & 4.68 & 3.34 & 3.23 & 2.70 & 32.8 & 36.3 \\
\hline 67 & 24.04 & 4.84 & 2.98 & 2.57 & 2.24 & 33.2 & 34.4 \\
\hline 136 & 25.17 & 5.10 & 2.99 & 2.71 & 2.57 & 34.8 & 36.0 \\
\hline 300 & 13.29 & 5.03 & 2.64 & 2.85 & 3.08 & 33.0 & 23.8 \\
\hline 465 & 24.22 & 5.03 & 2.14 & 2.76 & 3.40 & 34.0 & 34.2 \\
\hline 628 & 23.48 & 4.96 & 2.01 & 2.78 & 4.13 & 33.8 & 33.2 \\
\hline 788 & 25.70 & 5.06 & 1.86 & 2.99 & 4.39 & 32.4 & 35.6 \\
\hline 1718 & 25.57 & 4.90 & 1.51 & 2.80 & 5.04 & 29.2 & 34.8 \\
\hline 1497 & 26.94 & 5.17 & 1.29 & 2.49 & 7.50 & 31.8 & 35.9 \\
\hline 1807 & 26.41 & 5.10 & 1.08 & 2.37 & 5.582 & 34.7 & 35.0 \\
\hline 2164 & 0.00 & 0.00 & 0.00 & 0.00 & 0.00 & 32.7 & 0.0 \\
\hline 2472 & 0.50 & 5.74 & 52.18 & 1.76 & 6.79 & 35.0 & 60.2 \\
\hline 3142 & 27.29 & 5.63 & 0.80 & 1.85 & 7.87 & 34.7 & 35.6 \\
\hline 3863 & 25.28 & 5.20 & 0.71 & 1.50 & 8.07 & 27.6 & 32.7 \\
\hline
\end{tabular}


10.33 Data from Test 233

\begin{tabular}{|c|c|c|c|c|c|c|c|}
\hline $\begin{array}{c}\text { Reaction } \\
\text { Time }(\mathrm{h})\end{array}$ & $\begin{array}{c}\text { Soluble } \\
\text { NaTPB } \\
(\mathrm{mmol} / \mathrm{L})\end{array}$ & $\begin{array}{c}3 \mathrm{~PB} \\
(\mathrm{mmol} / \mathrm{L})\end{array}$ & $\begin{array}{c}2 \mathrm{~PB} \\
(\mathrm{mmol} / \mathrm{L})\end{array}$ & $\begin{array}{c}1 \mathrm{~PB} \\
(\mathrm{mmol} / \mathrm{L})\end{array}$ & $\begin{array}{c}\text { Phenol } \\
(\mathrm{mmol} / \mathrm{L})\end{array}$ & $\begin{array}{c}\text { Soluble } \\
\text { Boron } \\
(\mathrm{mmol} / \mathrm{L})\end{array}$ & $\begin{array}{c}\text { Soluble } \\
\text { Organic } \\
\text { Boron } \\
(\mathrm{mmol} / \mathrm{L})\end{array}$ \\
\hline 16 & 23.50 & 3.11 & 3.63 & 3.92 & 3.10 & 33.4 & 34.2 \\
\hline 87 & 23.74 & 4.79 & 3.26 & 3.15 & 2.47 & 32.5 & 34.9 \\
\hline 157 & 25.01 & 4.68 & 3.34 & 3.64 & 3.21 & 33.8 & 36.7 \\
\hline 322 & 24.93 & 4.44 & 3.58 & 3.01 & 3.34 & 35.7 & 36.0 \\
\hline 487 & 23.15 & 4.49 & 3.03 & 3.26 & 3.63 & 31.8 & 33.9 \\
\hline 651 & 22.20 & 4.90 & 2.51 & 3.30 & 4.04 & 32.8 & 32.9 \\
\hline 811 & 22.33 & 5.00 & 2.30 & 3.34 & 6.40 & 34.1 & 33.0 \\
\hline 1140 & 21.04 & 5.34 & 2.48 & 3.37 & 5.90 & 33.5 & 32.2 \\
\hline 1307 & 21.21 & 6.29 & 2.90 & 3.48 & 5.72 & 34.9 & 33.9 \\
\hline 1521 & 19.41 & 7.43 & 3.92 & 5.22 & 7.10 & 35.6 & 36.0 \\
\hline 1830 & 25.84 & .0 .00 & 0.00 & 0.00 & 0.00 & 34.3 & 25.8 \\
\hline 2190 & 11.44 & 8.64 & 7.86 & 5.95 & 8.75 & 33.2 & 33.9 \\
\hline 2501 & 8.20 & 8.61 & 8.38 & 6.57 & 10.56 & 34.1 & 31.8 \\
\hline 3169 & 3.43 & 7.36 & 9.47 & 7.96 & 14.04 & 35.9 & 28.2 \\
\hline 3890 & 0.70 & 3.10 & 8.91 & 7.86 & 16.40 & 38.2 & 20.6 \\
\hline
\end{tabular}

10.34 Data from Test 234

\begin{tabular}{|c|c|c|c|c|c|c|c|c|}
\hline $\begin{array}{l}\text { Reaction } \\
\text { Time (h) }\end{array}$ & $\begin{array}{c}\text { Soluble } \\
\text { NaTPB } \\
\text { (mmol/L) }\end{array}$ & $\begin{array}{c}3 P B \\
\text { (mmol/L) }\end{array}$ & $\begin{array}{c}2 \mathrm{~PB} \\
(\mathrm{mmol} / \mathrm{L})\end{array}$ & $\begin{array}{c}\text { 1PB } \\
\text { (mmol/L) }\end{array}$ & $\begin{array}{c}\text { Phenol } \\
\text { (mmol/L) }\end{array}$ & $\begin{array}{c}\text { Soluble } \\
\text { Boron } \\
\text { (mmol/L) }\end{array}$ & $\begin{array}{c}\text { Soluble } \\
\text { Organic } \\
\text { Boron } \\
\text { (mmol/L) }\end{array}$ & $\begin{array}{l}\text { Soluble } \\
\text { Potassium } \\
\text { (mmol/L) }\end{array}$ \\
\hline 17 & 1.59 & 3.56 & 2.46 & 3.18 & 2.31 & 11.8 & 10.8 & \\
\hline 90 & 1.60 & 2.84 & 2.52 & 4.84 & 3.23 & 12.9 & 11.8 & \\
\hline 157 & 1.62 & 4.24 & 4.79 & 3.67 & 2.90 & 15.3 & 14.3 & \\
\hline 249 & 1.54 & 3.44 & 5.43 & 5.41 & 3.72 & 18.1 & 15.8 & \\
\hline 413 & 0.41 & 6.17 & 12.62 & 8.61 & 4.39 & 29.5 & 27.8 & \\
\hline 578 & $<0.03$ & 1.97 & 14.20 & 12.54 & 4.26 & 32.1 & 28.7 & \\
\hline 742 & $<0.03$ & 0.49 & 11.32 & 15.96 & 4.34 & 32.6 & 27.8 & \\
\hline 906 & $<0.03$ & 0.09 & 8.68 & 18.19 & 4.59 & 34.4 & 27.0 & \\
\hline 1070 & $<0.03$ & $<0.04$ & 5.13 & 19.64 & 4.51 & 32.7 & 24.8 & \\
\hline 1234 & $<0.03$ & $<0.04$ & 2.37 & 19.20 & 4.51 & 35.6 & 21.6 & 1.05 \\
\hline 1397 & $<0.03$ & $<0.04$ & 0.99 & 18.29 & 4.76 & 36.2 & 19.3 & 7.15 \\
\hline 1611 & $<0.03$ & $<0.04$ & 0.55 & 15.31 & 5.97 & 34.0 & 15.9 & 1.67 \\
\hline 7919 & $<0.03$ & $<0.04$ & 0.19 & 11.63 & 7.03 & 34.2 & 77.9 & 1.91 \\
\hline 2277 & $<0.03$ & $<0.04$ & 0.05 & 7.70 & 8.29 & 37.4 & 7.8 & 1.64 \\
\hline 2586 & $<0.03$ & $<0.04$ & 0.05 & 5.36 & 9.40 & 39.4 & 5.5 & 1.71 \\
\hline
\end{tabular}




\subsection{Data from Test 235}

\begin{tabular}{|c|c|c|c|c|c|c|c|c|}
\hline $\begin{array}{c}\text { Reaction } \\
\text { Time }(\mathrm{h})\end{array}$ & $\begin{array}{c}\text { Soluble } \\
\text { NaTPB } \\
(\mathrm{mmol} / \mathrm{L})\end{array}$ & $\begin{array}{c}3 \mathrm{~PB} \\
(\mathrm{mmol} / \mathrm{L})\end{array}$ & $\begin{array}{c}2 \mathrm{~PB} \\
(\mathrm{mmol} / \mathrm{L})\end{array}$ & $\begin{array}{c}\text { 1PB } \\
(\mathrm{mmol} / \mathrm{L})\end{array}$ & $\begin{array}{c}\text { Phenol } \\
(\mathrm{mmol} / \mathrm{L})\end{array}$ & $\begin{array}{c}\text { Soluble } \\
\text { Boron } \\
(\mathrm{mmol} / \mathrm{L})\end{array}$ & $\begin{array}{c}\text { Soluble } \\
\text { Organic } \\
\text { Boron } \\
(\mathrm{mmol} / \mathrm{L})\end{array}$ & $\begin{array}{c}\text { Soluble } \\
\text { Potassium } \\
(\mathrm{mmol} / \mathrm{L})\end{array}$ \\
\hline 17 & 1.45 & 3.34 & 2.35 & 3.53 & 2.50 & 12.2 & 10.7 & \\
\hline 90 & 1.57 & 2.86 & 2.26 & 5.04 & 3.43 & 12.8 & 11.7 & \\
\hline 177 & 1.50 & 4.17 & 4.69 & 3.67 & 2.89 & 15.2 & 14.0 & \\
\hline 249 & 1.54 & 3.40 & 5.36 & 4.88 & 3.54 & 17.4 & 15.2 & \\
\hline 413 & 0.89 & 4.99 & 9.77 & 8.15 & 4.47 & 26.7 & 23.8 & \\
\hline 578 & $<0.03$ & 1.95 & 14.15 & 12.11 & 4.44 & 32.1 & 28.2 & \\
\hline 742 & $<0.03$ & 0.43 & 11.85 & 15.58 & 4.56 & 32.6 & 27.9 & \\
\hline 906 & $<0.03$ & 0.07 & 8.58 & 18.92 & 4.89 & 34.7 & 27.6 & \\
\hline 1070 & $<0.03$ & $<0.04$ & 4.42 & 20.22 & 4.99 & 33.0 & 24.7 & \\
\hline 1234 & $<0.03$ & $<0.04$ & 1.71 & 18.16 & 4.83 & 35.0 & 19.9 & 1.01 \\
\hline 1397 & $<0.03$ & $<0.04$ & 0.74 & 16.95 & 5.21 & 34.5 & 17.8 & 1.28 \\
\hline 1611 & $<0.03$ & $<0.04$ & 0.42 & 14.12 & 6.14 & 35.0 & 14.6 & 1.67 \\
\hline 1919 & $<0.03$ & $<0.04$ & 0.15 & 10.68 & 7.16 & 34.3 & 10.9 & 1.89 \\
\hline 2277 & $<0.03$ & $<0.04$ & 0.04 & 7.01 & 8.53 & 37.9 & 7.1 & 1.75 \\
\hline 2586 & $<0.03$ & $<0.04$ & 0.05 & 5.03 & 9.53 & 40.1 & 5.2 & 1.74 \\
\hline
\end{tabular}

\subsection{Data from Test 236}

\begin{tabular}{|c|c|c|c|c|c|c|c|}
\hline $\begin{array}{c}\text { Reaction } \\
\text { Time }(\mathrm{h})\end{array}$ & $\begin{array}{c}\text { Soluble } \\
\text { NaTPB } \\
(\mathrm{mmol} / \mathrm{L})\end{array}$ & $\begin{array}{c}3 \mathrm{~PB} \\
(\mathrm{mmol} / \mathrm{L})\end{array}$ & $\begin{array}{c}2 \mathrm{~PB} \\
(\mathrm{mmo} / \mathrm{L})\end{array}$ & $\begin{array}{c}1 \mathrm{~PB} \\
(\mathrm{mmol} / \mathrm{L})\end{array}$ & $\begin{array}{c}\text { Phenol } \\
(\mathrm{mmol} / \mathrm{L})\end{array}$ & $\begin{array}{c}\text { Soluble } \\
\text { Boron } \\
(\mathrm{mmol} / \mathrm{L})\end{array}$ & $\begin{array}{c}\text { Soluble } \\
\text { Organic } \\
\text { Boron } \\
(\mathrm{mmol} / \mathrm{L})\end{array}$ \\
\hline 18 & 5.42 & 4.40 & 2.71 & 3.15 & 2.57 & 16.2 & 15.7 \\
\hline 67 & 5.47 & 4.51 & 2.41 & 2.62 & 2.47 & 15.7 & 15.0 \\
\hline 136 & 5.44 & 4.44 & 2.14 & 2.94 & 3.13 & 17.3 & 15.0 \\
\hline 300 & 5.10 & 4.33 & 1.23 & 3.00 & 3.80 & 16.7 & 13.7 \\
\hline 465 & 5.38 & 4.39 & 0.70 & 2.69 & 4.51 & 16.7 & 13.2 \\
\hline 628 & 4.97 & 4.13 & 0.45 & 2.03 & 4.95 & 17.0 & 11.6 \\
\hline 788 & 5.28 & 4.15 & 0.38 & 1.98 & 5.34 & 16.6 & 11.8 \\
\hline 1118 & 5.17 & 4.00 & 0.25 & 1.52 & 6.17 & 12.9 & 10.9 \\
\hline 1497 & 4.92 & 3.94 & 0.20 & 0.93 & 6.42 & 17.8 & 10.0 \\
\hline 1807 & 5.07 & 3.88 & 0.18 & 0.75 & 6.31 & 20.3 & 9.9 \\
\hline 2164 & 5.33 & 3.94 & 0.18 & 0.51 & 6.78 & 21.0 & 10.0 \\
\hline 2472 & 5.21 & 4.17 & 0.18 & 0.39 & 7.21 & 22.0 & 9.9 \\
\hline 3142 & 5.58 & 4.36 & 0.16 & 0.34 & 8.34 & 25.3 & 10.4 \\
\hline 3863 & 5.36 & 3.92 & 0.16 & 0.20 & 8.30 & 21.5 & 9.6 \\
\hline
\end{tabular}


10.37 Data from Test 237

\begin{tabular}{|c|c|c|c|c|c|c|c|}
\hline $\begin{array}{c}\text { Reaction } \\
\text { Time }(\mathrm{h})\end{array}$ & $\begin{array}{c}\text { Soluble } \\
\text { NaTPB } \\
(\mathrm{mmol} / \mathrm{L})\end{array}$ & $\begin{array}{c}3 \mathrm{~PB} \\
(\mathrm{mmol} / \mathrm{L})\end{array}$ & $\begin{array}{c}2 \mathrm{~PB} \\
(\mathrm{mmol} / \mathrm{L})\end{array}$ & $\begin{array}{c}1 \mathrm{~PB} \\
(\mathrm{mmol} / \mathrm{L})\end{array}$ & $\begin{array}{c}\text { Phenol } \\
(\mathrm{mmol} / \mathrm{L})\end{array}$ & $\begin{array}{c}\text { Soluble } \\
\text { Boron } \\
(\mathrm{mmol} / \mathrm{L})\end{array}$ & $\begin{array}{c}\text { Soluble } \\
\text { Organic } \\
\text { Boron } \\
(\mathrm{mmol} / \mathrm{L})\end{array}$ \\
\hline 16 & 5.84 & 4.41 & 2.74 & 2.72 & 2.53 & 16.4 & 15.7 \\
\hline 87 & 5.42 & 4.41 & 2.43 & 2.88 & 2.62 & 16.0 & 15.1 \\
\hline 157 & 5.32 & 4.56 & 2.19 & 3.16 & 3.30 & 16.4 & 15.2 \\
\hline 322 & 4.11 & 8.67 & 3.58 & 3.42 & 4.10 & 23.5 & 19.8 \\
\hline 487 & 3.53 & 12.44 & 5.13 & 4.13 & 4.23 & 25.6 & 25.2 \\
\hline 651 & 1.65 & 13.71 & 6.63 & 4.44 & 4.71 & 28.4 & 26.4 \\
\hline 811 & 0.45 & 12.06 & 7.71 & 5.47 & 7.34 & 30.2 & 25.7 \\
\hline 976 & 0.07 & 9.60 & 9.72 & 6.40 & 6.14 & 30.1 & 25.8 \\
\hline 1140 & $<0.03$ & 6.60 & 10.00 & 7.34 & 4.95 & 30.8 & 24.0 \\
\hline 1307 & $<0.03$ & 4.81 & 10.51 & 8.98 & 6.58 & 32.4 & 24.3 \\
\hline 1521 & $<0.03$ & 3.26 & 10.57 & 10.76 & 6.96 & 34.5 & 24.6 \\
\hline 1830 & $<0.03$ & 2.43 & 5.69 & 11.91 & 10.54 & 34.9 & 20.1 \\
\hline 2190 & $<0.03$ & 2.00 & 2.15 & 10.30 & 11.14 & 34.4 & 14.5 \\
\hline 2501 & $<0.03$ & 2.18 & 1.35 & 8.17 & 13.38 & 35.0 & 11.7 \\
\hline
\end{tabular}

10.38 Data from Test 238

\begin{tabular}{|c|c|c|c|c|c|c|c|}
\hline $\begin{array}{c}\text { Reaction } \\
\text { Time }(\mathrm{h})\end{array}$ & $\begin{array}{c}\text { Soluble } \\
\text { NaTPB } \\
(\mathrm{mmol} / \mathrm{L})\end{array}$ & $\begin{array}{c}3 \mathrm{~PB} \\
(\mathrm{mmo} / \mathrm{L})\end{array}$ & $\begin{array}{c}2 \mathrm{~PB} \\
(\mathrm{mmol} / \mathrm{L})\end{array}$ & $\begin{array}{c}1 \mathrm{~PB} \\
(\mathrm{mmo} / \mathrm{L})\end{array}$ & $\begin{array}{c}\text { Phenol } \\
(\mathrm{mmo} / \mathrm{L})\end{array}$ & $\begin{array}{c}\text { Soluble } \\
\text { Boron } \\
(\mathrm{mmol} / \mathrm{L})\end{array}$ & $\begin{array}{c}\text { Soluble } \\
\text { Organic } \\
\text { Boron } \\
(\mathrm{mmo} / \mathrm{L})\end{array}$ \\
\hline 18 & 0.26 & 4.30 & 2.76 & 3.31 & 2.65 & 10.6 & 10.6 \\
\hline 67 & 0.20 & 4.33 & 2.43 & 2.84 & 2.53 & 10.8 & 9.8 \\
\hline 136 & 0.25 & 4.37 & 1.90 & 3.05 & 3.38 & 11.3 & 9.6 \\
\hline 300 & 0.17 & 3.89 & 0.65 & 2.86 & 4.12 & 11.6 & 7.6 \\
\hline 465 & 0.18 & 3.92 & 0.25 & 2.30 & 4.76 & 11.6 & 6.6 \\
\hline 628 & 0.15 & 3.54 & 0.29 & 1.62 & 5.03 & 12.1 & 5.6 \\
\hline 788 & 0.15 & 3.71 & 0.26 & 1.28 & 5.66 & 12.6 & 5.4 \\
\hline 1118 & 0.16 & 3.27 & 0.23 & 0.98 & 6.30 & 12.8 & 4.6 \\
\hline 1497 & 0.15 & 3.04 & 0.21 & 0.52 & 6.57 & 15.1 & 3.9 \\
\hline 1807 & 0.15 & 2.74 & 0.20 & 0.48 & 7.00 & 17.5 & 3.6 \\
\hline 2164 & 0.17 & 2.60 & 0.18 & 0.36 & 7.41 & 18.2 & 3.3 \\
\hline 2472 & 0.20 & 2.47 & 0.16 & 0.24 & 8.03 & 20.5 & 3.1 \\
\hline 3142 & 0.18 & 2.38 & 0.13 & 0.26 & 8.97 & 26.0 & 3.0 \\
\hline 3863 & 0.12 & 1.76 & 0.12 & 0.20 & 9.17 & 23.6 & 2.2 \\
\hline
\end{tabular}


10.39 Data from Test 239

\begin{tabular}{|c|c|c|c|c|c|c|c|}
\hline $\begin{array}{c}\text { Reaction } \\
\text { Time }(\mathrm{h})\end{array}$ & $\begin{array}{c}\text { Soluble } \\
\text { NaTPB } \\
(\mathrm{mmol} / \mathrm{L})\end{array}$ & $\begin{array}{c}3 \mathrm{~PB} \\
(\mathrm{mmol} / \mathrm{L})\end{array}$ & $\begin{array}{c}2 \mathrm{~PB} \\
(\mathrm{mmol} / \mathrm{L})\end{array}$ & $\begin{array}{c}1 \mathrm{~PB} \\
(\mathrm{mmol} / \mathrm{L})\end{array}$ & $\begin{array}{c}\text { Phenol } \\
(\mathrm{mmol} / \mathrm{L})\end{array}$ & $\begin{array}{c}\text { Soluble } \\
\text { Boron } \\
(\mathrm{mmol} / \mathrm{L})\end{array}$ & $\begin{array}{c}\text { Soluble } \\
\text { Organic } \\
\text { Boron } \\
(\mathrm{mmol} / \mathrm{L})\end{array}$ \\
\hline 16 & 0.26 & 4.09 & 2.31 & 3.56 & 3.25 & 10.6 & 10.2 \\
\hline 87 & 0.22 & 3.81 & 2.51 & 3.43 & 2.96 & 11.0 & 10.0 \\
\hline 157 & 0.22 & 2.99 & 2.99 & 4.48 & 3.59 & 12.5 & 10.7 \\
\hline 322 & 0.15 & 3.87 & 7.41 & 5.07 & 3.57 & 18.7 & 16.5 \\
\hline 487 & 0.18 & 4.32 & 8.90 & 5.68 & 3.56 & 20.9 & 19.1 \\
\hline 651 & 0.11 & 4.60 & 10.47 & 6.51 & 3.64 & 25.0 & 21.7 \\
\hline 811 & 0.09 & 4.53 & 11.95 & 7.50 & 7.26 & 28.7 & 24.1 \\
\hline 976 & $<0.03$ & 4.01 & 12.89 & 7.81 & 4.02 & 29.9 & 24.7 \\
\hline 1140 & $<0.03$ & 2.75 & 14.35 & 8.90 & 4.04 & 28.8 & 26.0 \\
\hline 1307 & $<0.03$ & 1.14 & 14.65 & 10.11 & 4.21 & 31.6 & 25.9 \\
\hline 1521 & $<0.03$ & 0.22 & 14.77 & 12.06 & 4.69 & 36.0 & 27.1 \\
\hline 1830 & $<0.03$ & 0.04 & 9.65 & 16.32 & 6.25 & 36.3 & 26.0 \\
\hline 2190 & $<0.03$ & 0.04 & 2.87 & 15.13 & 8.37 & 34.3 & 18.1 \\
\hline 2501 & $<0.03$ & 0.04 & 0.66 & 10.83 & 10.54 & 36.6 & 11.6 \\
\hline
\end{tabular}

10.40 Data from Test 240

\begin{tabular}{|c|c|c|c|c|c|c|c|}
\hline $\begin{array}{c}\text { Reaction } \\
\text { Time (h) }\end{array}$ & $\begin{array}{c}\text { Soluble } \\
\text { NaTPB } \\
(\mathrm{mmol} / \mathrm{L})\end{array}$ & $\begin{array}{c}3 \mathrm{~PB} \\
(\mathrm{mmol} / \mathrm{L})\end{array}$ & $\begin{array}{c}2 \mathrm{~PB} \\
(\mathrm{mmol} / \mathrm{L})\end{array}$ & $\begin{array}{c}1 \mathrm{~PB} \\
(\mathrm{mmol} / \mathrm{L})\end{array}$ & $\begin{array}{c}\text { Phenol } \\
(\mathrm{mmol} / \mathrm{L})\end{array}$ & $\begin{array}{c}\text { Soluble } \\
\text { Boron } \\
(\mathrm{mmol} / \mathrm{L})\end{array}$ & $\begin{array}{c}\text { Soluble } \\
\text { Organic } \\
\text { Boron } \\
(\mathrm{mmol} / \mathrm{L})\end{array}$ \\
\hline 18 & 5.48 & 4.47 & 2.75 & 3.12 & 2.57 & 15.8 & 15.8 \\
\hline 67 & 5.35 & 4.42 & 2.40 & 2.60 & 2.34 & 15.4 & 14.8 \\
\hline 136 & 5.53 & 4.54 & 2.21 & 2.93 & 3.08 & 16.3 & 15.2 \\
\hline 300 & 5.12 & 4.41 & 1.14 & 3.19 & 3.79 & 16.7 & 13.9 \\
\hline 465 & 5.36 & 4.43 & 0.74 & 2.51 & 4.59 & 16.5 & 13.0 \\
\hline 628 & 4.87 & 4.13 & 0.46 & 2.08 & 4.92 & 17.4 & 11.5 \\
\hline 788 & 5.30 & 4.21 & 0.38 & 1.22 & 6.14 & 16.6 & 11.1 \\
\hline 1118 & 5.04 & 3.98 & 0.24 & 1.48 & 6.06 & 13.9 & 10.7 \\
\hline 1283 & 4.79 & 3.75 & 0.20 & 1.12 & 6.12 & 18.6 & 9.9 \\
\hline 1497 & 4.82 & 3.96 & 0.20 & 0.96 & 6.42 & 17.7 & 9.9 \\
\hline 1807 & 4.90 & 3.86 & 0.19 & 0.67 & 6.42 & 21.2 & 9.6 \\
\hline 2164 & 5.25 & 4.01 & 0.19 & 0.47 & 6.92 & 20.7 & 9.9 \\
\hline 2472 & 5.01 & 4.14 & 0.19 & 0.32 & 7.59 & 22.3 & 9.7 \\
\hline 3142 & 5.33 & 4.36 & 0.16 & 0.33 & 8.62 & 26.9 & 10.2 \\
\hline 3863 & 5.07 & 3.90 & 0.13 & 0.17 & 8.61 & 23.8 & 9.3 \\
\hline
\end{tabular}




\subsection{Data from Test 241}

\begin{tabular}{|c|c|c|c|c|c|c|c|}
\hline $\begin{array}{c}\text { Reaction } \\
\text { Time }(\mathrm{h})\end{array}$ & $\begin{array}{c}\text { Soluble } \\
\text { NaTPB } \\
(\mathrm{mmol} / \mathrm{L})\end{array}$ & $\begin{array}{c}3 \mathrm{~PB} \\
(\mathrm{mmol} / \mathrm{L})\end{array}$ & $\begin{array}{c}2 \mathrm{~PB} \\
(\mathrm{mmol} / \mathrm{L})\end{array}$ & $\begin{array}{c}\text { 1PB } \\
(\mathrm{mmol} / \mathrm{L})\end{array}$ & $\begin{array}{c}\text { Phenol } \\
(\mathrm{mmol} / \mathrm{L})\end{array}$ & $\begin{array}{c}\text { Soluble } \\
\text { Boron } \\
(\mathrm{mmol} / \mathrm{L})\end{array}$ & $\begin{array}{c}\text { Soluble } \\
\text { Organic } \\
\text { Boron } \\
(\mathrm{mmol} / \mathrm{L})\end{array}$ \\
\hline 16 & 5.65 & 4.28 & 2.66 & 2.65 & 2.47 & 16.1 & 15.2 \\
\hline 87 & 5.28 & 4.35 & 2.30 & 2.83 & 2.68 & 15.5 & 14.8 \\
\hline 157 & 5.22 & 4.48 & 2.03 & 3.08 & 3.47 & 16.8 & 14.8 \\
\hline 322 & 4.54 & 4.68 & 1.67 & 3.05 & 4.17 & 17.6 & 13.9 \\
\hline 487 & 4.62 & 5.40 & 1.88 & 3.10 & 5.03 & 18.1 & 15.0 \\
\hline 651 & 3.21 & 8.42 & 3.47 & 3.43 & 5.77 & 23.8 & 18.5 \\
\hline 811 & 2.32 & 10.29 & 4.76 & 3.86 & 16.48 & 28.2 & 21.2 \\
\hline 976 & 0.92 & 11.04 & 6.32 & 4.04 & 6.99 & 27.7 & 22.3 \\
\hline 1140 & 0.20 & 9.38 & 7.50 & 4.64 & 6.25 & 29.2 & 21.7 \\
\hline 1307 & $<0.03$ & 7.28 & 8.49 & 5.66 & 7.18 & 29.2 & 21.5 \\
\hline 1521 & $<0.03$ & 7.19 & 6.30 & 7.46 & 8.27 & 32.2 & 21.0 \\
\hline 1830 & $<0.03$ & 6.15 & 2.99 & 7.32 & 16.13 & 32.7 & 16.5 \\
\hline 2190 & $<0.03$ & 5.63 & 1.21 & 5.83 & 12.20 & 32.0 & 12.7 \\
\hline 2501 & $<0.03$ & 6.14 & 0.82 & 4.24 & 14.36 & 32.7 & 11.2 \\
\hline
\end{tabular}

10.42 Data from Test 242

\begin{tabular}{|c|c|c|c|c|c|c|c|}
\hline $\begin{array}{c}\text { Reaction } \\
\text { Time }(\mathrm{h})\end{array}$ & $\begin{array}{c}\text { Soluble } \\
\text { NaTPB } \\
(\mathrm{mmol} / \mathrm{L})\end{array}$ & $\begin{array}{c}3 \mathrm{~PB} \\
(\mathrm{mmol} / \mathrm{L})\end{array}$ & $\begin{array}{c}2 \mathrm{~PB} \\
(\mathrm{mmol} / \mathrm{L})\end{array}$ & $\begin{array}{c}\text { 1PB } \\
(\mathrm{mmol} / \mathrm{L})\end{array}$ & $\begin{array}{c}\text { Phenol } \\
(\mathrm{mmol} / \mathrm{L})\end{array}$ & $\begin{array}{c}\text { Soluble } \\
\text { Boron } \\
(\mathrm{mmol} / \mathrm{L})\end{array}$ & $\begin{array}{c}\text { Soluble } \\
\text { Organic } \\
\text { Boron } \\
(\mathrm{mmol} / \mathrm{L})\end{array}$ \\
\hline 18 & 0.24 & 4.26 & 2.72 & 3.08 & 2.53 & 10.3 & 10.3 \\
\hline 67 & 0.24 & 4.29 & 2.27 & 2.78 & 2.54 & 10.2 & 9.6 \\
\hline 136 & 0.25 & 4.41 & 1.46 & 3.16 & 3.57 & 11.5 & 9.3 \\
\hline 300 & 0.20 & 4.16 & 0.63 & 2.80 & 4.34 & 11.6 & 7.8 \\
\hline 465 & 0.17 & 3.87 & 0.36 & 2.13 & 4.97 & 11.1 & 6.5 \\
\hline 628 & 0.17 & 3.68 & 0.25 & 1.53 & 5.44 & 12.1 & 5.6 \\
\hline 788 & 0.15 & 3.58 & 0.20 & 0.80 & 3.22 & 12.2 & 4.7 \\
\hline 1718 & 0.17 & 3.28 & 0.20 & 0.90 & 6.92 & 12.2 & 4.6 \\
\hline 1497 & 0.17 & 3.13 & 0.16 & 0.44 & 6.98 & 14.3 & 3.9 \\
\hline 1807 & 0.17 & 2.85 & 0.15 & 0.35 & 7.26 & 17.2 & 3.5 \\
\hline 2164 & 0.18 & 2.79 & 0.15 & 0.26 & 7.79 & 8.8 & 3.4 \\
\hline 2472 & 0.18 & 2.68 & 0.11 & 0.20 & 8.46 & 19.5 & 3.2 \\
\hline 3142 & 0.18 & 2.69 & 0.12 & 0.23 & 9.34 & 25.8 & 3.2 \\
\hline 3863 & 0.13 & 2.08 & 0.10 & 0.08 & 9.28 & 23.2 & 2.4 \\
\hline
\end{tabular}


10.43 Data from Test 243

\begin{tabular}{|c|c|c|c|c|c|c|c|}
\hline $\begin{array}{c}\text { Reaction } \\
\text { Time }(\mathrm{h})\end{array}$ & $\begin{array}{c}\text { Soluble } \\
\text { NaTPB } \\
(\mathrm{mmol} / \mathrm{L})\end{array}$ & $\begin{array}{c}3 \mathrm{~PB} \\
(\mathrm{mmol} / \mathrm{L})\end{array}$ & $\begin{array}{c}2 \mathrm{~PB} \\
(\mathrm{mmol} / \mathrm{L})\end{array}$ & $\begin{array}{c}1 \mathrm{~PB} \\
(\mathrm{mmol} / \mathrm{L})\end{array}$ & $\begin{array}{c}\text { Phenol } \\
(\mathrm{mmo} / \mathrm{L})\end{array}$ & $\begin{array}{c}\text { Soluble } \\
\text { Boron } \\
(\mathrm{mmol} / \mathrm{L})\end{array}$ & $\begin{array}{c}\text { Soluble } \\
\text { Organic } \\
\text { Boron } \\
(\mathrm{mmol} / \mathrm{L})\end{array}$ \\
\hline 16 & 0.24 & 3.71 & 1.76 & 4.10 & 3.29 & 10.6 & 9.8 \\
\hline 87 & 0.20 & 3.76 & 2.25 & 3.44 & 2.99 & 10.7 & 9.7 \\
\hline 157 & 0.22 & 3.22 & 2.51 & 4.47 & 3.71 & 12.3 & 10.4 \\
\hline 322 & 0.15 & 3.41 & 6.96 & 5.04 & 3.49 & 19.0 & 15.6 \\
\hline 487 & 0.17 & 3.90 & 8.98 & 6.22 & 3.45 & 21.4 & 19.3 \\
\hline 651 & 0.10 & 4.25 & 10.73 & 7.01 & 3.62 & 25.1 & 22.1 \\
\hline 811 & 0.07 & 3.82 & 11.60 & 8.05 & 3.97 & 28.7 & 23.5 \\
\hline 976 & $<0.03$ & 2.71 & 12.80 & 8.55 & 3.80 & 28.9 & 24.1 \\
\hline 1140 & $<0.03$ & 1.15 & 12.85 & 10.66 & 5.28 & 30.7 & 24.7 \\
\hline 1307 & $<0.03$ & 0.29 & 11.74 & 12.14 & 4.32 & 31.2 & 24.2 \\
\hline 1521 & 0.03 & 0.04 & 9.70 & 14.67 & 4.91 & 33.9 & 24.4 \\
\hline 1830 & $<0.03$ & $<0.04$ & 5.11 & 16.14 & 5.68 & 35.4 & 21.3 \\
\hline 2190 & $<0.03$ & $<0.04$ & 1.59 & 13.98 & 7.33 & 31.7 & 15.6 \\
\hline 2501 & $<0.03$ & $<0.04$ & 0.34 & 9.35 & 8.80 & 36.4 & 9.8 \\
\hline
\end{tabular}




\subsection{Distribution}

Abell, G. E., 704-3N

Attaway, B. N., 773-A

Barnes, J. L., 704-3N

Barnes, M. J., 773-A

Beck, S. B., 704-3N

Bibler, N. E., 773-A

Bragg, T. K., 241-197H

Brooke, J. N., 773-A

Britt, T. E., 703-H

Carlson, J. D., 703-H

Carter, J. T., 704-25S

Cauthen, G. L., 241-119H

Clark, W. C., 704-56H

Crawford, C. L., 773-41A

Cussler, Dr. E., 704-3N

Davis, N. R., 703-H

Dimenna, R. A., 773-42A

Doughty, D. E., 704-56H

Dworjanyn, L. O., 779-2A

Eibling, R. E., 704-T

Elder, H. H., 704-S

Fink, S. D., 773-A

Fondeur, F. 773-62A

Fowler, J. R., 704-3N

Fowler, R. C., 241-152H

Geeting, M. W., 773-24A

Griffin, J. C., 773-A

Hang, T., 773-42AHay, M. S., 773-A

Herrara, H. F., 703-H

Hester, J. R. 703-H

Hitchler, M. J., CCC-3

Hobbs, D. T., 773-A

Holtzscheiter, E. W., 773-A

Hsu, C. W., 773-A

Hudson, P. I., 704-3N

ITP Files c/o Wiest, A. G., 241-119H

Jacobs, R. A., 704-3N

Jamison, M. E., 703-H

Johnson, M. D., 703-H

Keefer, M. T., 704-56H

Kirkland, P. S., 703-46A

Kosiancic, 704-3N

Landon, L. F., 704-T

Lewis, B. L., 703-H

Lex, T. J., 703-H

Lowe, P. E., 773-41A

McCabe, D. J., 773-42A

McCullough, J. W., 703-H

Melton, W. L., 241-154H

Miller, M. S., 704-56H

Monahon, T. M., 703-H

Montini, M. J., 704-56H

Morin, J. P., 703-H

Murphy, 704-3N

Nash, C. A., 773-42A

Nelson, L. M., 773-43A

Papouchado, L. M., 773-A

Paul, P. K., 773-42A

Peterson, R. A., 773-A

Pervis, D. A., 241-152H

Piccolo, S. F., 704-3N

Poirier, M. R., 676-T
Polochko, M. J., 773-A

Randall, C. T., 704-T

Rueter, K. J., 706-S

Rutland, P. L., 704-196N

Satterfield, R. M., 703-H

Scott, A. B., 703-H

Spires, R. H., 703-H

Stevens, W. E., 773-A

Suggs, P. C., 704-3N

Swingle, R. F., 773-A

Tamosaitis, W. L., 773-A

Taylor, G. A., $704-196 \mathrm{~N}$

Thomas, J. K., CCC-3

TIM, 703-43A

VanPelt, W. B., 676-1T

Walker, D. D., 773-A

Watson, Dr. J., 704-3N

Wilmarth, W. R., 773-42A

WPTS Files, 773-A, c/o C. Canada, 773-A

Wright, G. T., 773-A

Young, J. E., 773-A

Van Pelt, W. B., 679-T

Walker, D. D., 773-A

Walker, W. C., 241-119H

Wilmarth, W. R., 773-42A

Wooten, A. L., CCC-3

Wright, G. T., 773-A

WPT-LWG Files, 773-A

TIM (4), 703-43A

RECORD ADMINSTRATION, 773-52A 